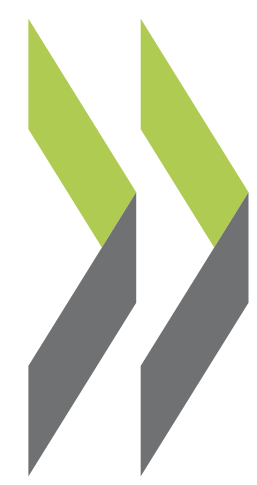

OECD Economics Department Working Papers No. 524

Globalisation and Inflation in the OECD Economies

Nigel Pain, Isabell Koske, Marte Sollie 


\section{Unclassified}

ECO/WKP(2006)52

Organisation de Coopération et de Développement Economiques

Organisation for Economic Co-operation and Development

21-Nov-2006

ECONOMICS DEPARTMENT

English text only

\section{GLOBALISATION AND INFLATION IN THE OECD ECONOMIES}

ECONOMICS DEPARTMENT WORKING PAPERS No. 524

by

Nigel Pain, Isabell Koske and Marte Sollie

All Economics Department Working Papers are available through OECD's Internet Web site at www.oecd.org/eco/working_papers

JT03218198

Document complet disponible sur OLIS dans son format d'origine

Complete document available on OLIS in its original format 


\section{ABSTRACT/RÉSUMÉ \\ GLOBALISATION AND INFLATION IN THE OECD ECONOMIES}

Over the past 25 years inflation has moderated considerably in all OECD economies. At the same time, the production of many goods and services has become increasingly internationalised and the level of trade between the OECD and non-OECD economies has risen markedly. This paper investigates the extent to which the observed changes in the inflation process can be attributed to the increasing integration of non-OECD economies into the global economy. The results of the analysis show that $i$ ) import prices have become a more important driver of domestic consumer prices since the mid-1990s; ii) the sensitivity of inflation to domestic economic conditions has declined whereas the sensitivity to foreign economic conditions has risen, working through import prices; and iii) the strong GDP growth in the non-OECD economies over the past five years has contributed to the growth of real oil and metals prices. A scenario analysis shows that globalisation has put upward pressure on inflation via higher commodity prices and downward pressure via lower non-commodity import prices with the latter effect having dominated in most OECD economies.

JEL Classification: E31, E37, E52, F15

Key words: globalisation, inflation, monetary policy, simulation

\section{MONDIALISATION ET INFLATION DANS LES ÉCONOMIES DE L’OCDE}

Au cours des 25 dernières années, l'inflation a considérablement diminué dans toutes les économies de l'OCDE. Pendant ce temps, la production de nombreux biens et services est devenue de plus en plus internationalisée et le niveau du commerce entre les pays de l'OCDE et les pays non membres a sensiblement augmenté. Ce papier étudie dans quelle mesure les changements observés dans le mécanisme d'inflation peuvent être attribués à l'intégration croissante des pays non membres de l'OCDE dans l'économie mondiale. Les résultats de l'analyse montrent que i) les prix d'importation jouent un rôle plus important dans la détermination des prix de consommation domestiques depuis le milieu des années 1990 ; ii) la sensibilité de l'inflation aux conditions économiques domestiques a diminué alors que la sensibilité aux conditions économiques extérieures a augmenté, en jouant à travers les prix d'importation; et iii) la croissance forte du PIB dans les pays non membres au cours des cinq dernières années a contribué à l'augmentation des prix réels du pétrole et des métaux. Les simulations montrent que la globalisation a entraîné des pressions inflationnistes via des prix des matières premières plus élevés et des pressions désinflationnistes via des prix des importations des produits hors matières premières plus faibles. Le dernier effet semble avoir dominé dans la plupart des pays de l'OCDE.

Classification JEL : E31, E37, E52, F15

Mots clés : mondialisation, inflation, politique monétaire, simulation

Copyright OECD 2006

Applications for permissions to reproduce or translate all, or part of, this document should be made to the Head of Publications Service, OECD, 2 rue André Pascal, 75775 Paris Cedex 16, France. 


\section{TABLE OF CONTENTS}

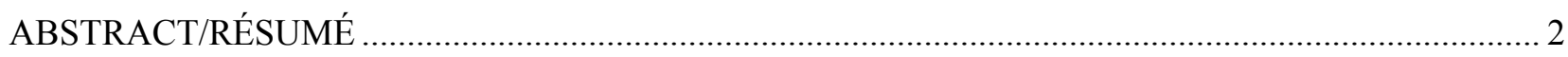

GLOBALISATION AND INFLATION IN THE OECD ECONOMIES …............................................. 5

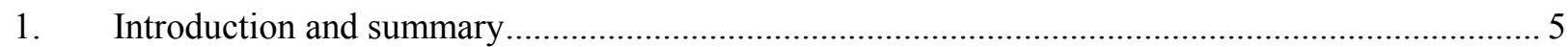

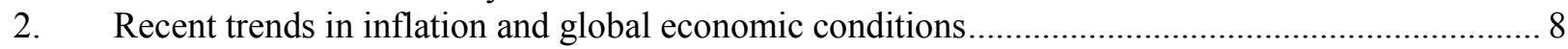

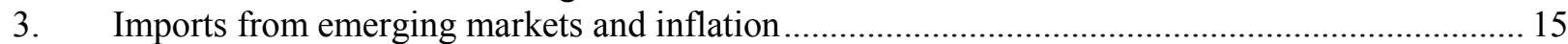

3.1 Estimates of the direct impact of imports from non-OECD Asia on OECD consumer price

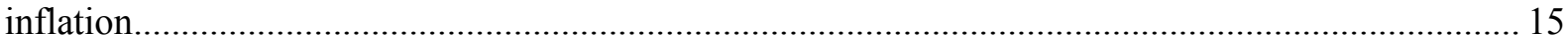

3.2 Estimates of the direct impact of imports from the non-OECD on OECD import

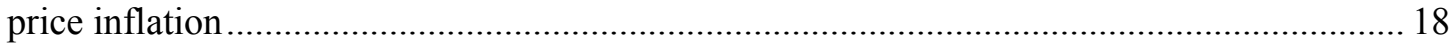

4. The impact of non-OECD output growth on commodity prices ................................................ 20

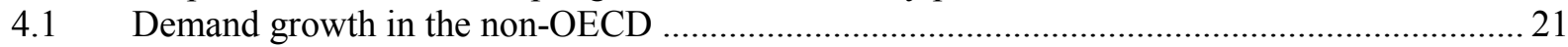

4.2 Estimates of the impact of output growth on commodity prices .............................................. 24

4.3 Estimates of the impact of non-OECD growth on commodity prices ...................................... 25

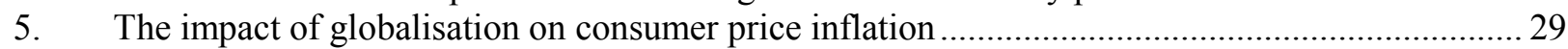

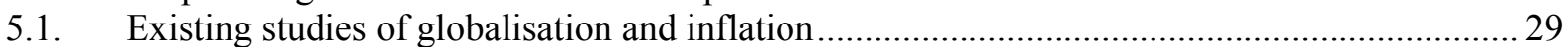

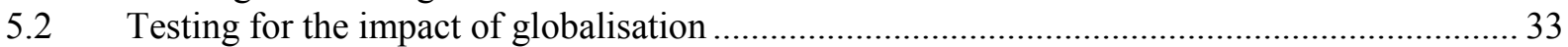

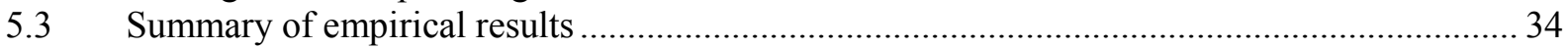

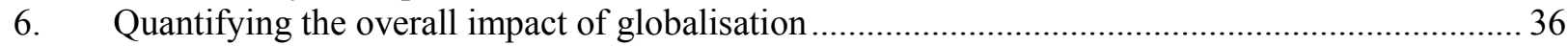

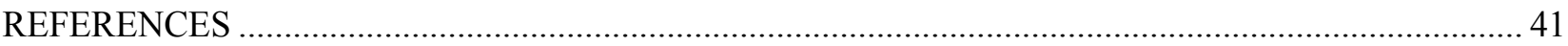

APPENDIX 1: GLOBALISATION AND CONSUMER PRICE INFLATION …................................... 45

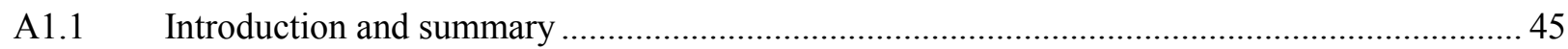

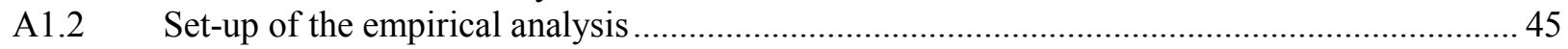

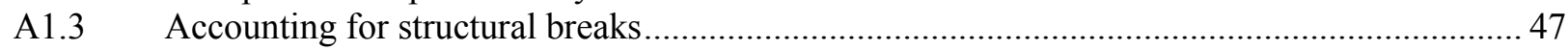

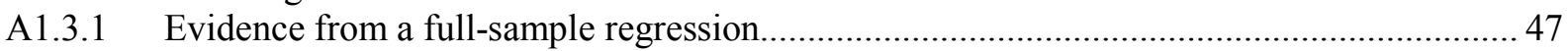

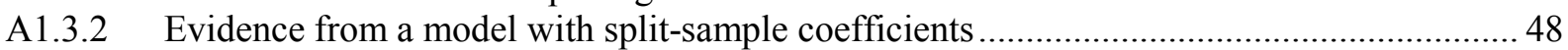

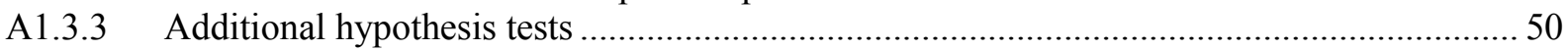

APPENDIX 2: GLOBALISATION AND COMMODITY PRICES …................................................. 56

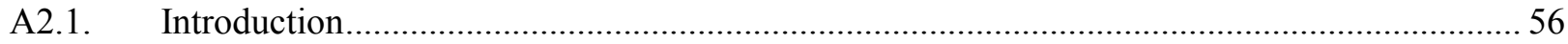

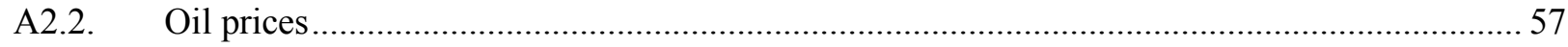

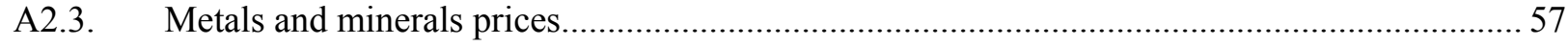

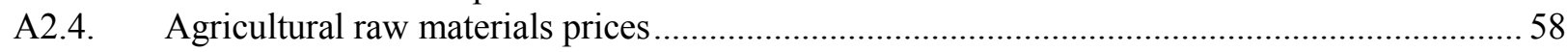

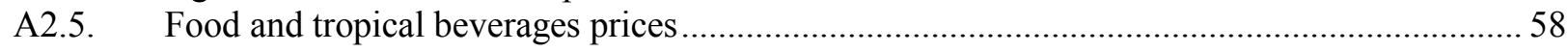

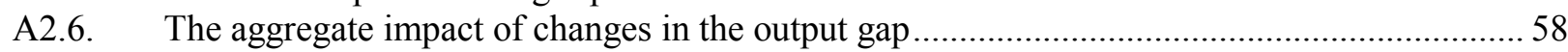

\section{Boxes}

Box 1. The impact of imports from emerging markets on inflation. 


\section{Tables}

1. Average import content of domestic demand

2. Average annual consumer price inflation, scenario analysis 1995Q1-2005Q4

3. Average annual consumer price inflation, scenario analysis 2000Q1-2005Q4

A1.1 Summary of the main regression results

A1.2 Regression results, 1980-1994

A1.3 Regression results 1995-2005

A1.4 Average elasticity of inflation with respect to import prices

A1.5 Hypotheses tests

A2.1 Alternative oil price equations

A2.2 Estimation results for non-commodity prices

\section{Figures}

1. Consumer price inflation in selected OECD countries

2. Inflation variability in selected OECD countries

3. Import prices and producer prices in selected OECD countries

4. Decomposition of import prices into its commodity and non-commodity components

5. Share of non-OECD countries in total world trade

6. Average annual GDP growth rate in OECD and non-OECD countries

7. Inward FDI stock

8. OECD imports from non-OECD countries

9a. Real oil and metals prices

9b. Real agricultural prices

10. Goods and services import prices in the United States

11. Oil consumption, 1995 and 2005

12. Consumption of aluminium, 2002 and 2005

13. Consumption of copper, 2002 and 2005

14. Consumption of nickel, 2002 and 2005

15. The world output gap

16a. Removing the impact of non-OECD growth on real oil prices

16b. The profile of real oil prices

17a. Removing the impact of non-OECD growth on real metals prices

17b. The profile of real metals prices

18. The impact on consumer price inflation from removing globalisation effects 2000-05

A2.1 Real commodity prices. Per cent effect of a temporary increase in output gaps 
ECO/WKP(2006)52

\title{
GLOBALISATION AND INFLATION IN THE OECD ECONOMIES
}

\author{
by
}

\author{
Nigel Pain, Isabell Koske and Marte Sollie ${ }^{1,2}$
}

1.

Introduction and summary

1. Over the past 25 years consumer price inflation has moderated considerably in all OECD economies, and also worldwide. The decline in OECD inflation from above $10 \%$ in the early 1980s to around 2\% over the decade from 1995-2005 has been accompanied by a reduction in the variability of inflation and cross-country dispersion. These developments have coincided with a marked increase in the extent of globalisation, with the production of many goods and services becoming increasingly internationalised and the level of trade in goods and services between the OECD and non-OECD economies rising as a share of OECD GDP. The analysis in this paper reviews and extends recent work undertaken at the IMF, the BIS and the US Federal Reserve Board in order to quantify the contribution of particular aspects of globalisation to the decline in OECD inflation. In particular, wider allowance is made for possible price level effects from globalisation, a larger number of countries are included in the sample and the separate impacts of commodity and non-commodity import prices are considered. ${ }^{3}$

2. Ultimately, inflation should be determined by monetary policy. But many other factors can influence inflation and in the short to medium term it can be difficult to assess whether any observed moderation in inflation results from monetary policy, structural factors -- such as globalisation -- or just good fortune. Globalisation itself, as reflected in trade and foreign direct investment, potentially affects inflation through a variety of channels (IMF, 2006a; Kohn, 2006). Enhanced trade integration with lowercost economies may help to hold down domestic inflation by depressing trade prices and increasing the share of imports in domestic demand. Related to this, enhanced product market competition may have reduced the mark-ups of domestic producers. These forces and the internationalisation of production may also have helped to raise the cyclical influence of global capacity utilisation on domestic price inflation (Borio and Filardo, 2006). Against this must be set the extent to which the strong globalisation-related growth in many non-OECD economies, and especially China, is putting upward pressure on the prices of many commodities.

1. The authors are members of the Macroeconomic Analysis and Systems Management Division and Country Studies 4 Division of the Economics Department of the OECD. They are grateful to Pete Richardson, Mike Feiner, Jorgen Elmeskov and other colleagues in the Economics Department for helpful comments and suggestions, and to Diane Scott for assistance in preparing the document. The material in Box 1 was prepared by Paul van den Noord and Christophe Andre and published in OECD Economic Outlook No.79.

2. This paper was prepared as part of the Economic Department's contribution to the OECD's horizontal study of Globalisation and Structural Adjustment, and was previously presented to Working Party No.1 of the OECD Economic Policy Committee.

3. The differences between the analysis in this paper and other studies of globalisation and inflation are described in greater detail in section 5 and in Appendix 1 of this paper. 
3. The main globalisation-related findings from the new econometric analyses of consumer and commodity prices in this paper are as follows:

- Import prices are found to have become a significantly more important influence on domestic consumer prices since the mid-1990s, coinciding with the growing participation of non-OECD countries in international goods and services trade.

- The impact of import prices on domestic prices in all countries over the past decade is estimated to be significantly larger than the weight of imported goods and services in domestic demand, suggesting that competition from lower-priced imports has placed pressure on domestic producers in import-competing industries to lower the mark-ups of prices over domestic costs.

- The cyclical sensitivity of inflation to domestic economic conditions has declined. At the same time, domestic inflation has become more sensitive to foreign economic conditions, working through import prices. However, there is no evidence of a robust significant impact from global output gaps in addition to that embodied in import prices.

- The strong GDP growth in the non-OECD economies over the past five years is found to be an important factor underlying the recent growth of real oil prices and real metals prices. A scenario analysis in which the non-OECD economies are assumed to grow at the same (lower) rate as the OECD economies since 2000 is found to be associated with a decline in real oil prices from baseline by $20-40 \%$ by the fourth quarter of 2005 , and a decline in real metals prices of just over $10 \%$ from their baseline. This removes some, but not all of the strong growth in these commodity prices over recent years.

4. The econometric findings are also used to quantify the overall impact of particular aspects of globalisation on consumer price inflation in OECD countries over the period from 2000 to 2005. Two facets of globalisation are considered -- the growth in commodity prices estimated to have resulted from strong output growth in the non-OECD economies, and a decline in the average rate of non-commodity import price inflation that is estimated to have resulted from higher levels of trade with non-OECD economies. Both of these estimates are uncertain and so a range of possible outcomes is considered in the quantification exercise.,

5. On balance, if such changes had not occurred, it is likely that inflation would have been higher in all the OECD economies considered, all else being equal, consistent with the view that globalisation has had a disinflationary effect. For most countries globalisation is estimated to have been associated with a decline in the rate of consumer price inflation of between 0 to $1 / 4$ percentage point per annum since 2000 . The impact is found to be a little larger in many European economies than elsewhere.

6. Even at the peak of the possible range of net effects the estimated impact on annual consumer price inflation appears to be modest, and no greater than the potential change in annual inflation that could result from a change in indirect taxes or administered prices. However, these calculations take the behaviour of domestic costs as given. To the extent that aspects of globalisation may be helping to restrain

4. Detailed results of the simulation exercise summarised in the following paragraphs are reported in Tables 2 and 3 and Figure 18 in section 6.

5. A rise of $1 \%$ in annual inflation is considered as a lower estimate of the impact that a slowing of globalisation would have had on non-commodity import prices, with a rise of $2 \%$ considered as an upper bound. These estimates for non-commodity import prices are discussed in greater detail in section 3 of the paper. The estimates for commodity prices are described in greater detail in section 4 . 
the cost of capital or labour costs (Rodrick, 1999; Dumont et al., 2006), and also because of the potential feedback of changes in price inflation to wages, it is possible that the implicit net disinflationary impact of globalisation on price inflation is understated in this paper. ${ }^{6}$ The same holds for inflation expectations, if globalisation has led to a decline in inflation expectations or helped expectations to become better anchored.

7. Globalisation-related developments generate considerable challenges to monetary policy makers, even if they are continuing to place some downward pressure on inflation in almost all economies. Identifying the extent and persistence of structural change in the economy is difficult and could result in policy mistakes. Going forward, a number of implications emerge from the analysis:

- To the extent that globalisation is changing the price level of imported non-commodity goods and services, the econometric analysis implies that in the long term there will be an effect only on the domestic price level rather than on domestic inflation. However, the adjustment to this new steady state is likely to be a lengthy process that will persist over several years to come, especially if the prices of traded services also begin to decline significantly relative to the prices of non-traded services. ${ }^{7}$

- As regards non-oil commodities, increased supply should eventually lead to a reversal of currently high real metals prices, at least if past behaviour is a guide to the future.

- As regards oil, continued strong growth in the non-OECD economies can be expected to help keep prices high in real terms. At the margin, however, the effects of this may be attenuated in the longer-term as the non-OECD economies begin to attain less energy-intensive stages of development.

- The uncertainty about the relative strengths of the various influences on inflation suggests that policymakers should examine developments in headline inflation as well as core inflation (Bean, 2006). The latter is usually regarded as a better signal of ongoing inflationary pressures, but the former will reflect both influences from globalisation. ${ }^{8}$ If the favourable external conditions for low inflation begin to wane going forward, higher nominal interest rates may be required to keep inflation low.

8. The remainder of the paper is structured as follows. Section 2 provides a short overview of inflation-related developments and some key indicators of the world economy that are drawn on in the analytical work. Section 3 then uses a simple accounting framework to derive estimates of the initial impact that trade with China and other low-cost producers has had on consumer price inflation in the OECD economies over the past decade. Key findings from new estimates of the influence of non-OECD economies on selected commodity prices are discussed in section 4 . The wider importance of globalisation and international trade for consumer price inflation is then addressed in section 5, which first reviews the range of evidence based on existing studies and then provides new estimates based on an econometric analysis of the factors determining consumer price inflation in the OECD economies. Section 6 goes on to

6. Indeed, recent work presented in Pain et al. (2006) is suggestive of such effects being present.

7. The disinflationary impacts might be weakened by real exchange rate appreciations in non-OECD economies.

8. Since headline inflation may be rather volatile, short-run changes in headline inflation may not always be very informative. Nonetheless, persistent movements in headline inflation over the medium to long run may contain useful information for monetary policy makers and are taken into account by many central banks when assessing inflation pressures. 
evaluate the overall impact of commodity and non-commodity price influences in the context of scenario analyses using these new estimates. The main paper is complemented by two appendices outlining the work referred to in greater detail. A detailed econometric analysis of the determinants of consumer price inflation in the OECD economies is provided in Appendix 1, and an overview of the reduced form commodity price equations is provided in Appendix 2.

\section{Recent trends in inflation and global economic conditions}

9. Over the past 25 years inflation has fallen considerably across OECD countries. In the early 1980s average inflation was above $10 \%$ in most OECD countries, compared with 2 to $3 \%$ since the second half of the 1990s (see Figure 1). Much of this decline occurred during the first half of the 1980s when average inflation fell by over 1 percentage point per annum. Inflation rates continued to decline in subsequent years, though much more slowly. This fall in average inflation rates has been accompanied by a decline in inflation variability (see Figure 2) and also in inflation expectations. The standard deviation of annual consumer price inflation has declined from above $3 \%$ in the early $1980 \mathrm{~s}$ to around $0.5 \%$ in recent years.

10. A number of different factors have contributed to the fall in both average inflation and inflation variability; the focus here is on the role of external factors. Figure 3 compares the evolution of the aggregate price deflator for imported goods and services with domestic producer prices in manufacturing over the period 1980 to 2005 . On average, import prices declined relative to producer prices during this period. ${ }^{9}$ Separating aggregate import prices into commodity and non-commodity components indicates that the rate of growth of non-commodity prices was the driving force behind the low overall rate of price inflation for imported goods and services (Figure 4). Since the early 1990s non-commodity import prices have risen at a very moderate rate and in some countries have even declined. More recently, the modest rate of non-commodity import price inflation has been partly offset by rising prices for commodity imports.

11. The low import price inflation in OECD countries can in part be attributed to the rising trade integration of low-cost countries from Asia and Latin America. As shown in Figure 5, the share of nonOECD countries in total world trade has increased since the beginning of the 1990s: from about a quarter of total world trade in 1990 to about a third in 2005. The rise in the trade share of non-OECD countries reflects both an increased openness of these countries as well as higher GDP growth rates compared with OECD countries (see Figure 6). Between 1980 and 2005 the GDP of non-OECD countries grew by 5\% per annum on average, compared with growth of $3 \%$ per annum in the OECD countries.

12. The integration of non-OECD countries into international trade and production networks has also progressed since the mid-1990s, albeit from a low level. The global stock of foreign direct investment relative to global GDP has increased throughout the 1990s (Figure 7). While this increase mainly reflected intra-OECD flows, inward FDI to non-OECD countries also picked up, particularly in the mid-1990s. Coinciding with the rise in international FDI flows, imports of OECD countries from non-OECD countries have also risen markedly from their low level in early to mid-1990 (Figure 8). In part, this trend reflects the recent strengthening of oil and other commodity prices. But it mainly reflects the increasing extent of international sourcing of finished and intermediate goods and services from the non-oil producing countries in the non-OECD.

9. Using disaggregated EU import price data (classified at the 8-digit level) Kaplinsky (2005) demonstrates that the proportion of sectors in which import prices fell between 1988 and 2001 is the higher the lower the per capita income of the country of origin. 
Figure 1. Consumer price inflation in selected OECD countries

In per cent
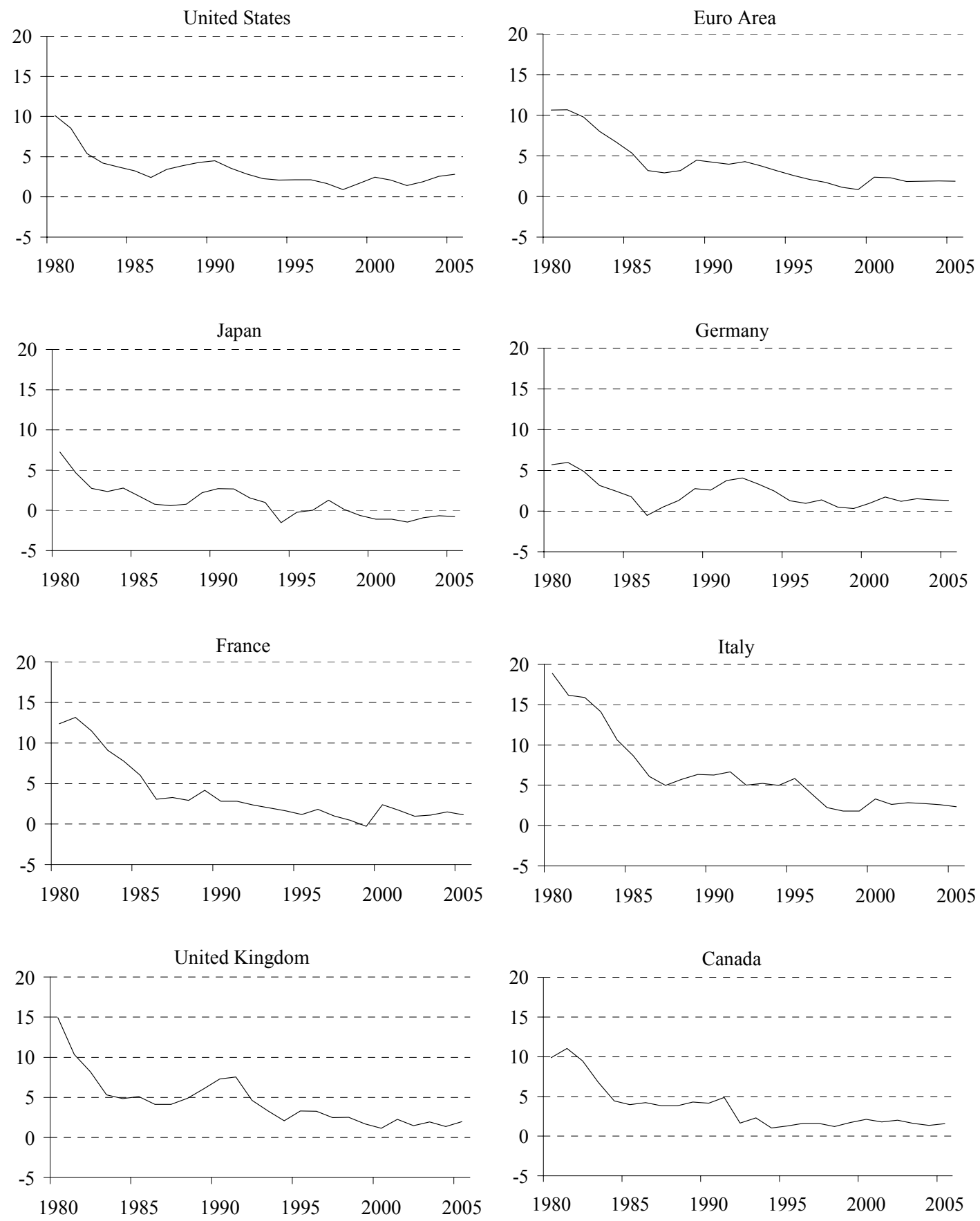

Source: OECD Economic Outlook database. 
Figure 2. Inflation variability in selected OECD countries
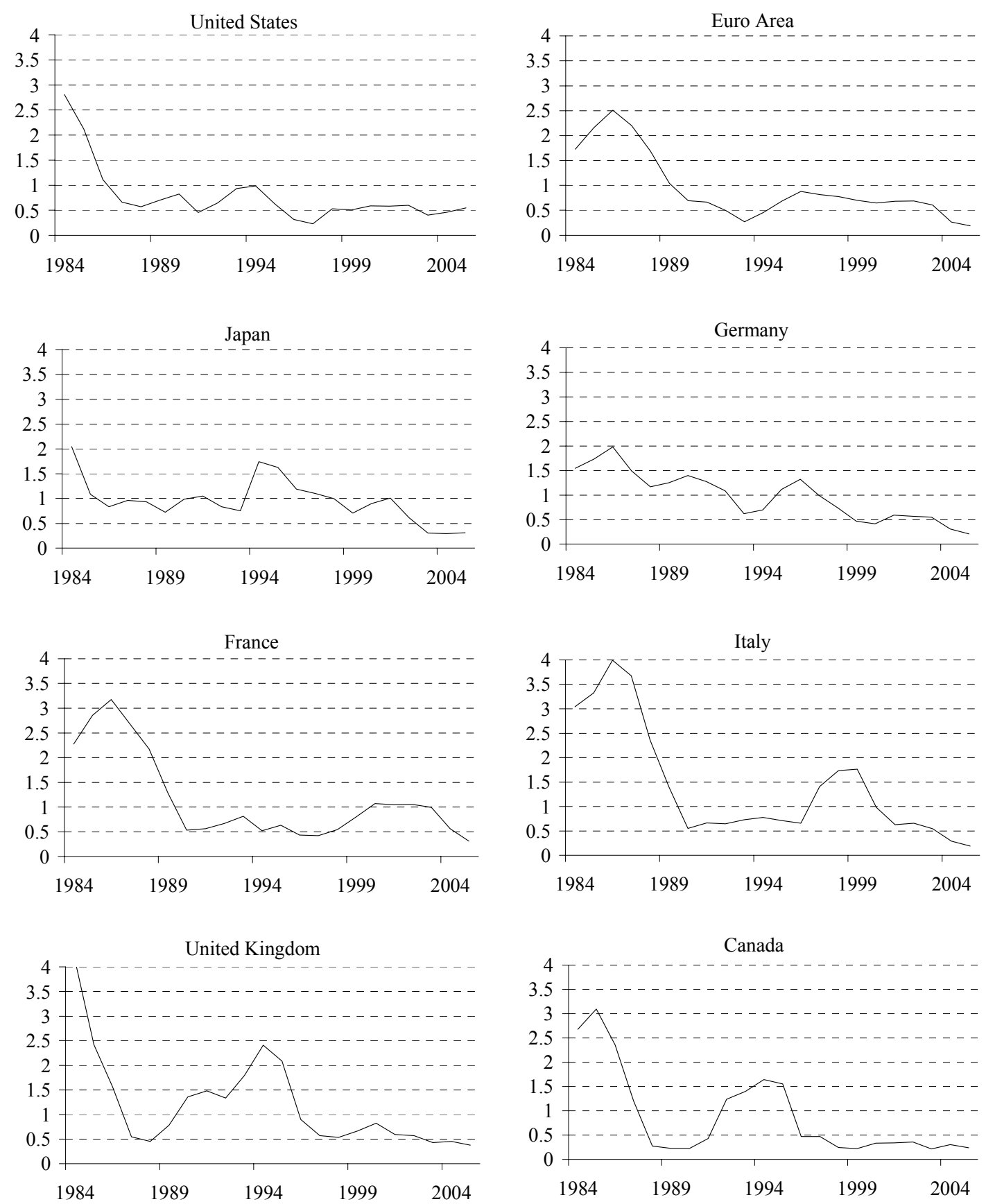

Note: Inflation variability is measured as the standard deviation of consumer price inflation, where the standard deviation is calculated over a rolling five-year period.

Source: OECD Economic Outlook database. 


\section{Figure 3. Import prices and producer prices in selected OECD countries}

$$
1985=1
$$
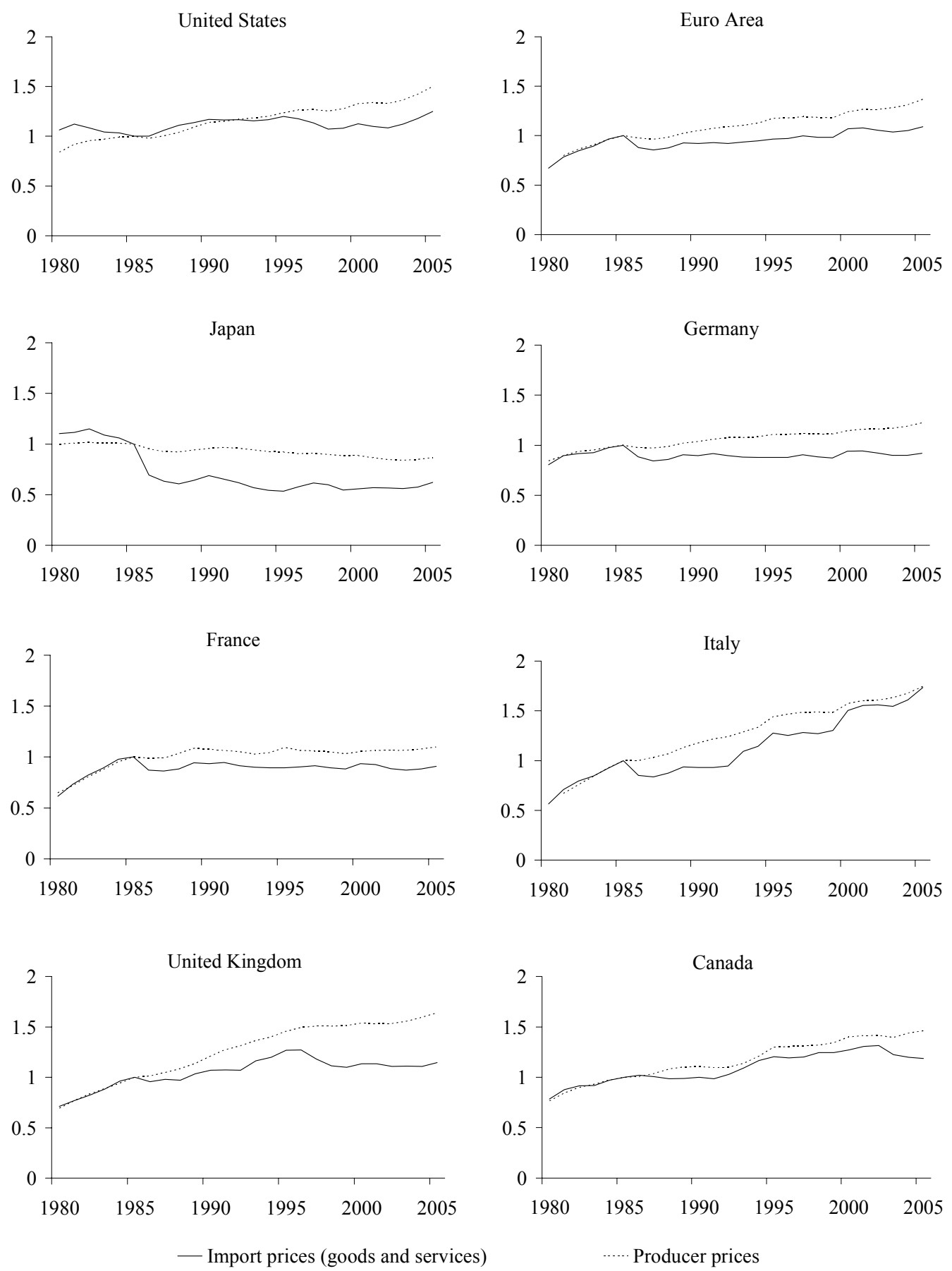

Note: Producer price indices cover manufacturing goods for all countries apart from Italy, where the index covers industrial goods.

Sources: OECD Economic Outlook database, OECD Main Economic Indicators database. 
Figure 4. Decomposition of import prices into its commodity and non-commodity components

$$
1985=1
$$
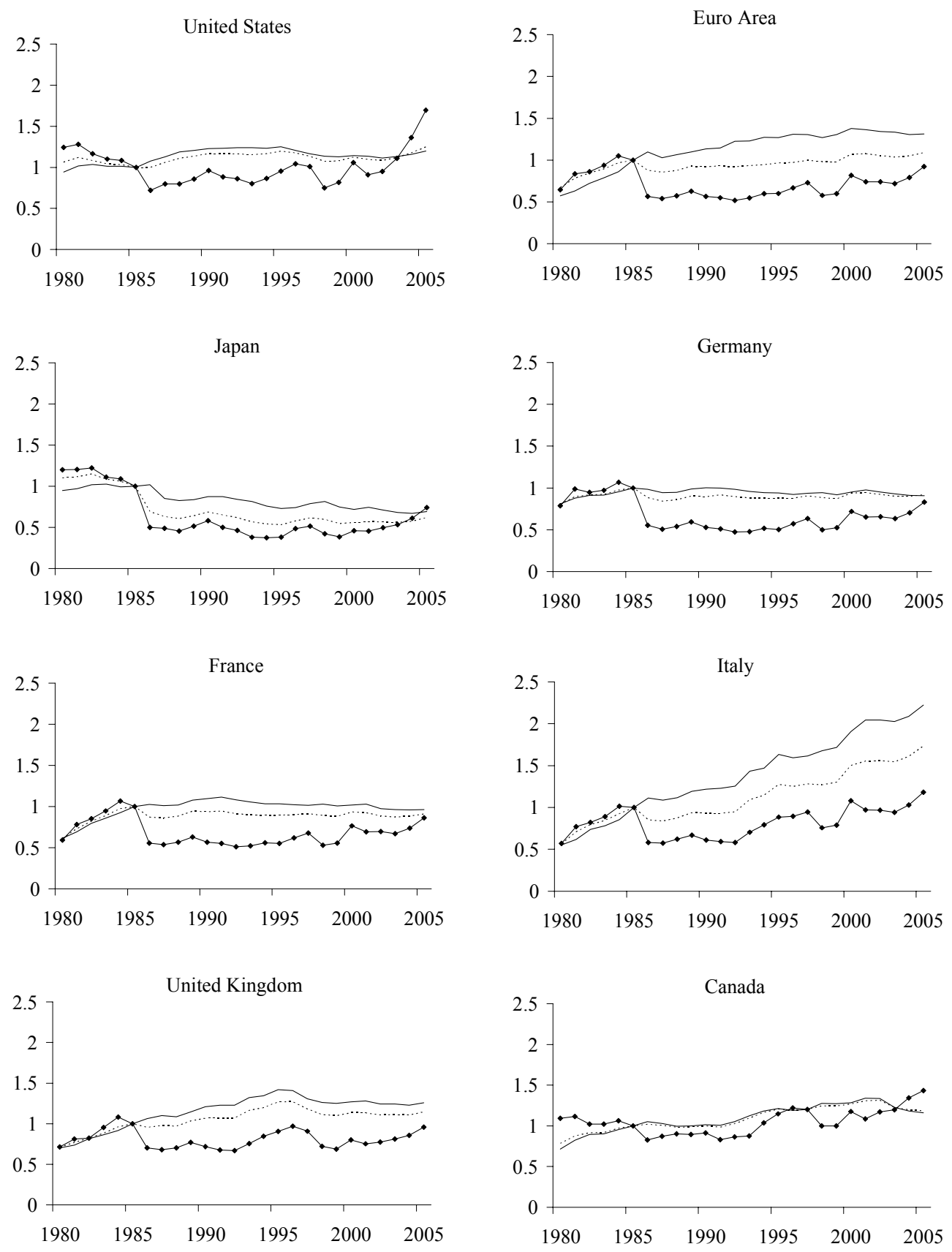

..... Total imports (goods and services)

— Non-commodity imports (goods and services)

$\rightarrow$ Commodity imports

Source: OECD Economic Outlook database. 
Figure 5. Share of non-OECD countries in total world trade

Percentage points

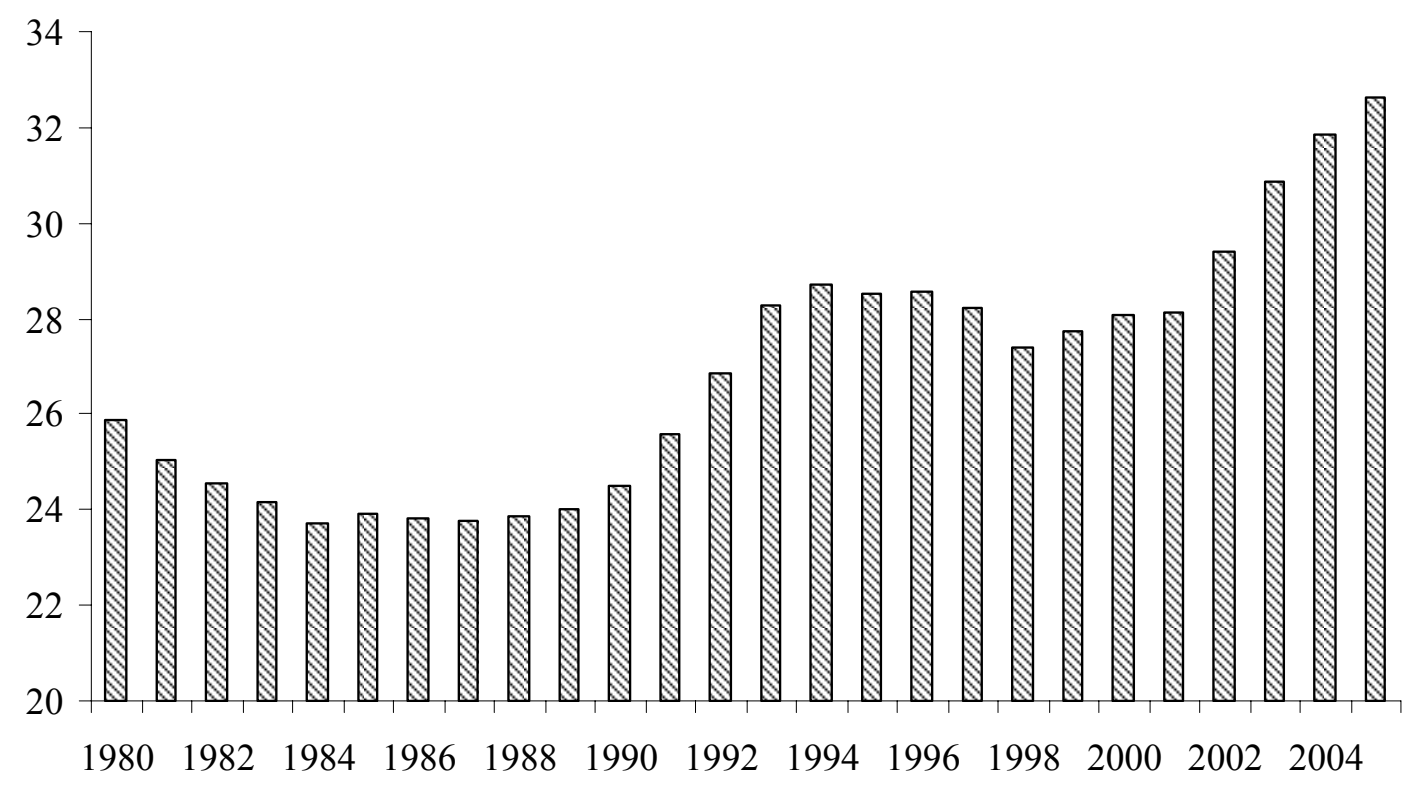

Source: OECD estimates.

Figure 6. Average annual GDP growth rate in OECD and non-OECD countries In per cent

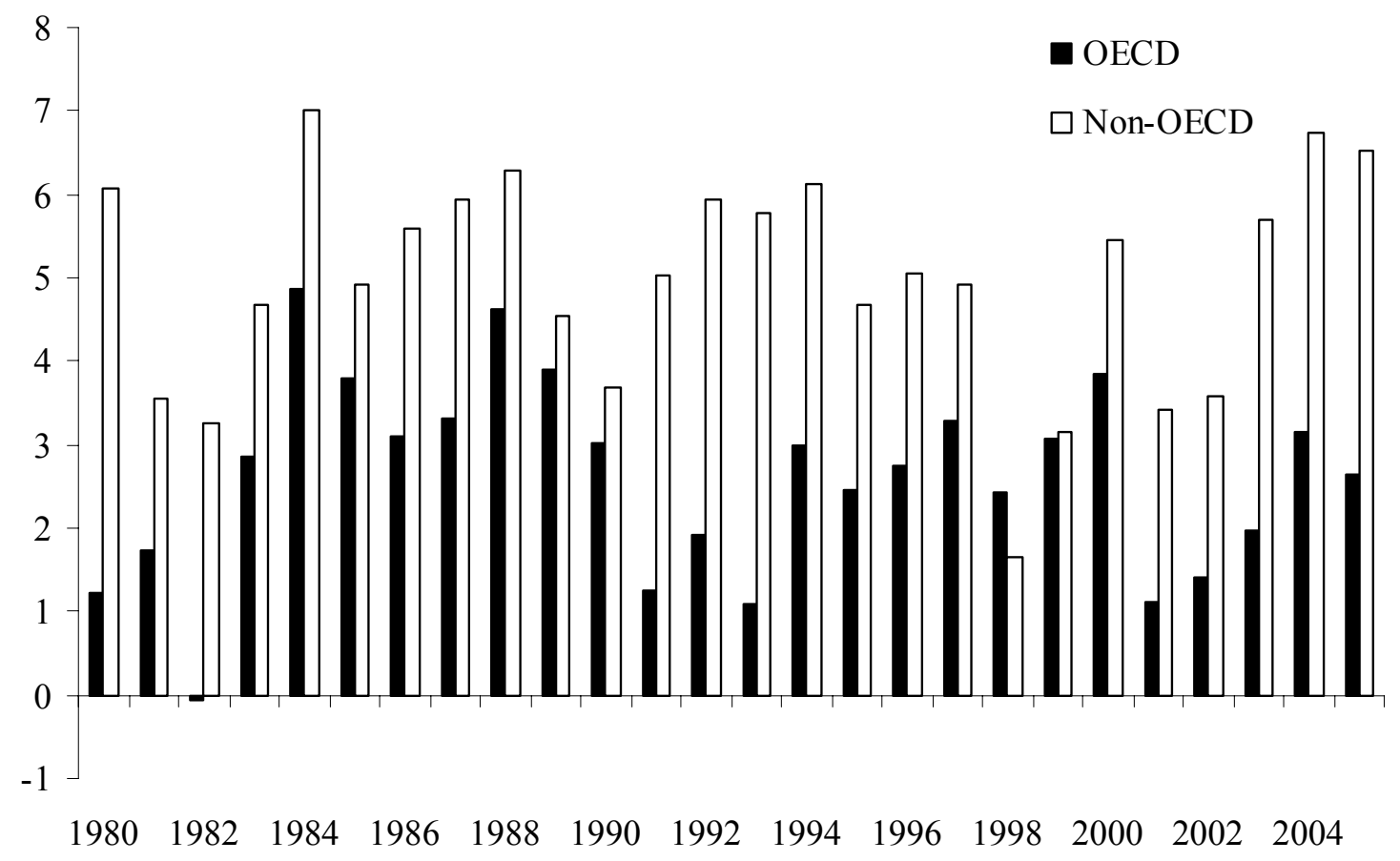

Source: IMF World Economic Outlook database. 
Figure 7. Inward FDI stock

Per cent of world GDP

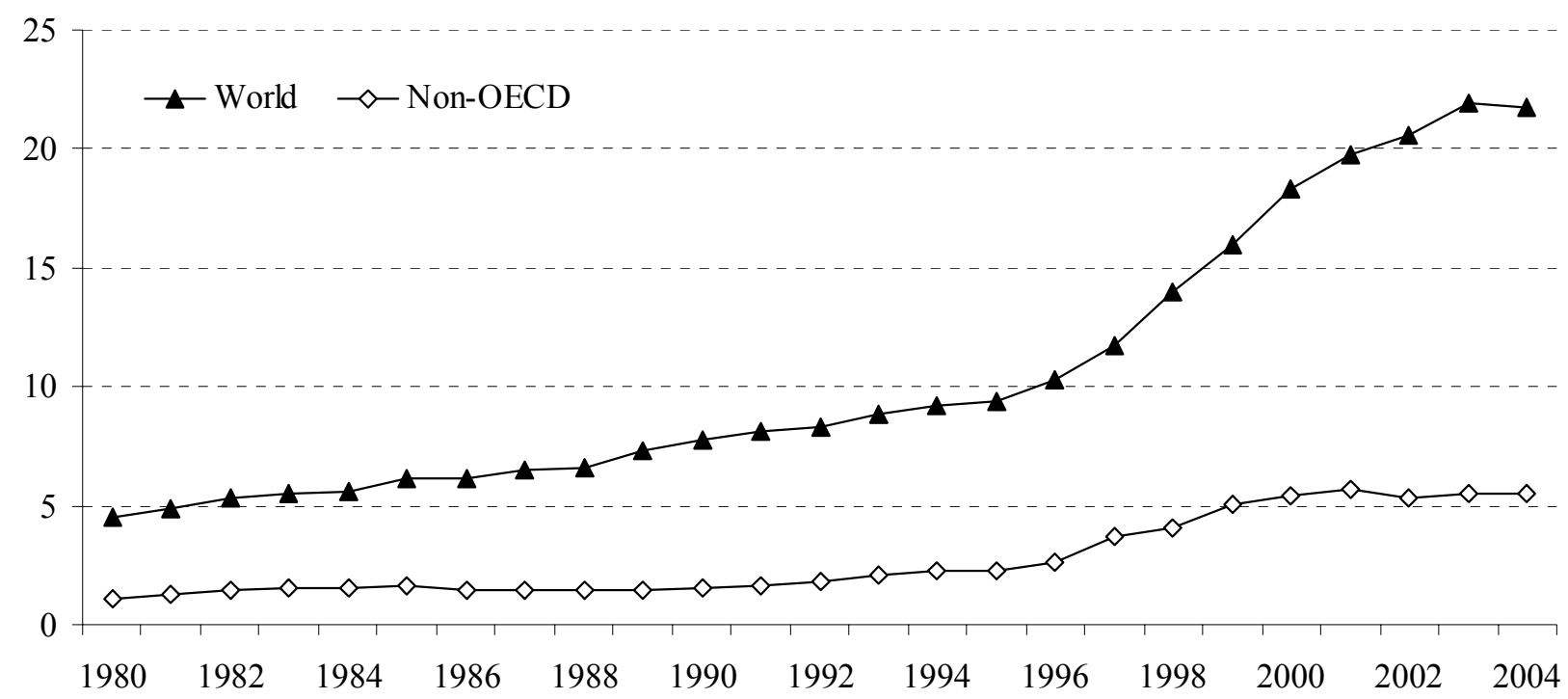

Sources: UNCTAD World Investment Report database and IMF World Economic Outlook database.

\section{Figure 8. OECD imports from non-OECD countries}

Per cent of GDP, current prices

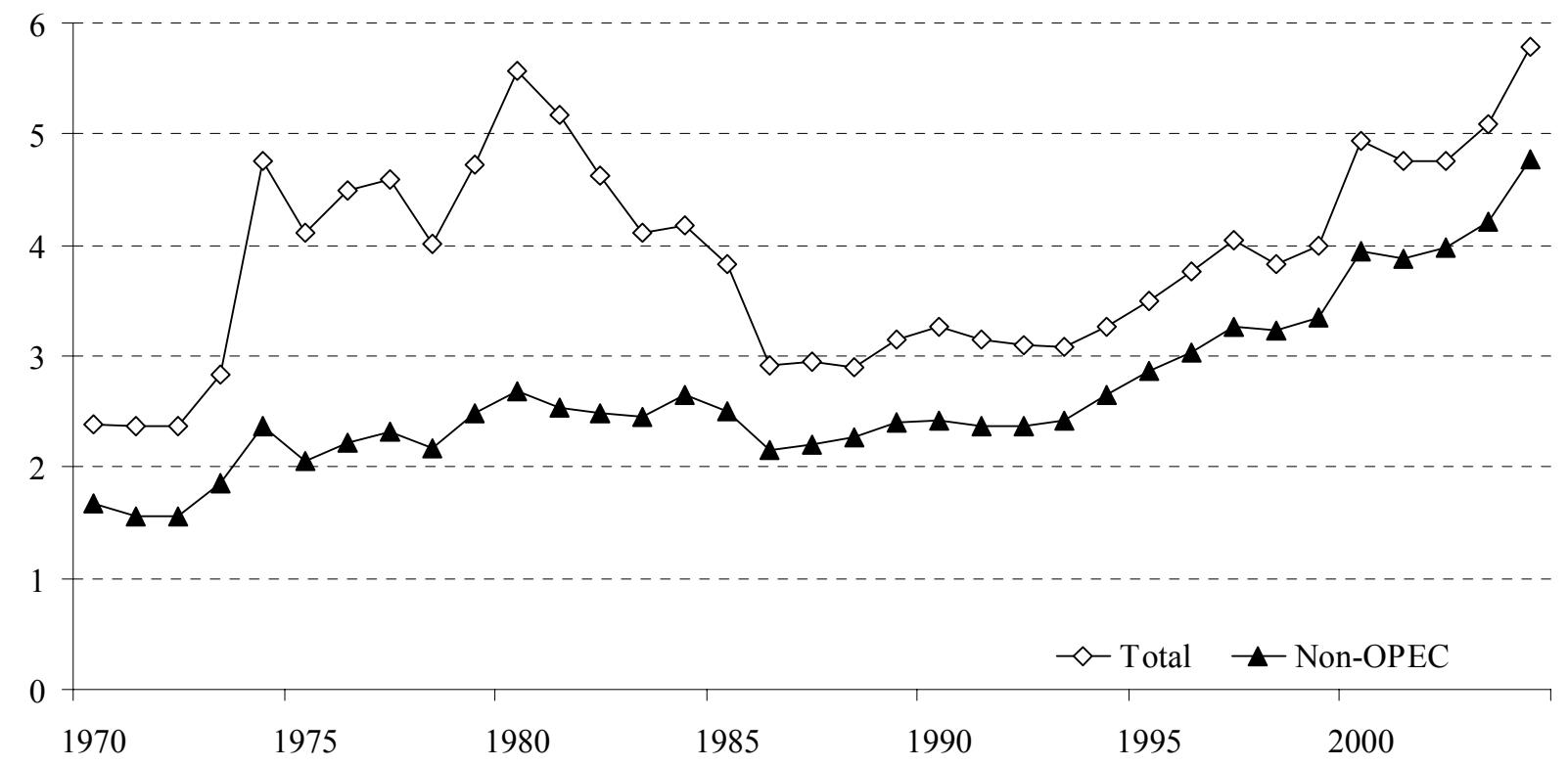

Sources: OECD International Trade Statistics database and Economic Outlook database. 
13. During the past three years the prices of several commodities have moved towards or past historical peaks in real terms, when expressed relative to weighted world export prices in US dollars (Figure 9a). ${ }^{10}$ These increases have been especially marked for real oil and metals prices. Between the fourth quarter of 2003 and the fourth quarter of 2005, oil prices rose by $74 \%$ in real terms, with metals prices increasing by $47 \%$ in real terms. ${ }^{11}$ Additional increases have taken place in 2006 . The size and persistence of recent increases is unusual but, as can be seen from Figure 9a, not outside all historical experience.

14. In contrast to oil and metals prices, the real prices of agricultural raw materials, foods and tropical beverages have not risen in recent years and currently remain well below historical peaks (Figure 9b). Within the broad agricultural commodity groups there are some commodities that are partial substitutes for oil and products with a high oil content, so that changes in oil prices can be propagated to other commodity prices (IMF, 2006b). To date, however, any such spillovers appear to have been limited.

\section{Imports from emerging markets and inflation}

15. The increasing importance of China and other lower-cost producers in global production networks is likely to have placed downward pressure on the global prices of many goods and services, and hence import prices in OECD countries, through several different channels. This section discusses the findings from a number of studies that have sought to estimate the initial impact of imports from lowercost producers on either domestic inflation or on the growth rate of import prices.

\subsection{Estimates of the direct impact of imports from non-OECD Asia on OECD consumer price inflation}

16. Using the simple accounting framework set out in Box 1, it can be shown that over the past decade imports from China and, to a lesser extent, other dynamic Asian economies, have placed downward pressure on the rate of consumer price inflation in the United States and the euro area (OECD, 2006). In the reported calculations this arises from two sources -- an increase in import penetration by lower-price Asian producers, and the differences between the rate of growth of their export prices and producer prices in the importing economies. Overall, the combined impact effect of imports from China and other dynamic Asian economies is estimated to have reduced domestic inflation in the United States by 0.1 percentage point per annum on average from 1996 to 2005. In the euro area, it is estimated to have reduced domestic inflation by 0.3 percentage point per annum between 2000 and 2005. Prior to that point, the effect was negligible.

10. The rise relative to domestic output or consumer prices is less marked, with trade prices having declined in real terms (Pain et al., 2005).

11. The price series for metals and the agricultural commodities are composite indicators produced by the Hamburg Institute for World Economics (HWWA). The oil price series is the price of Brent crude. 
Figure 9a. Real oil and metals prices

$2000=1$; deflated by world export prices in US dollar terms

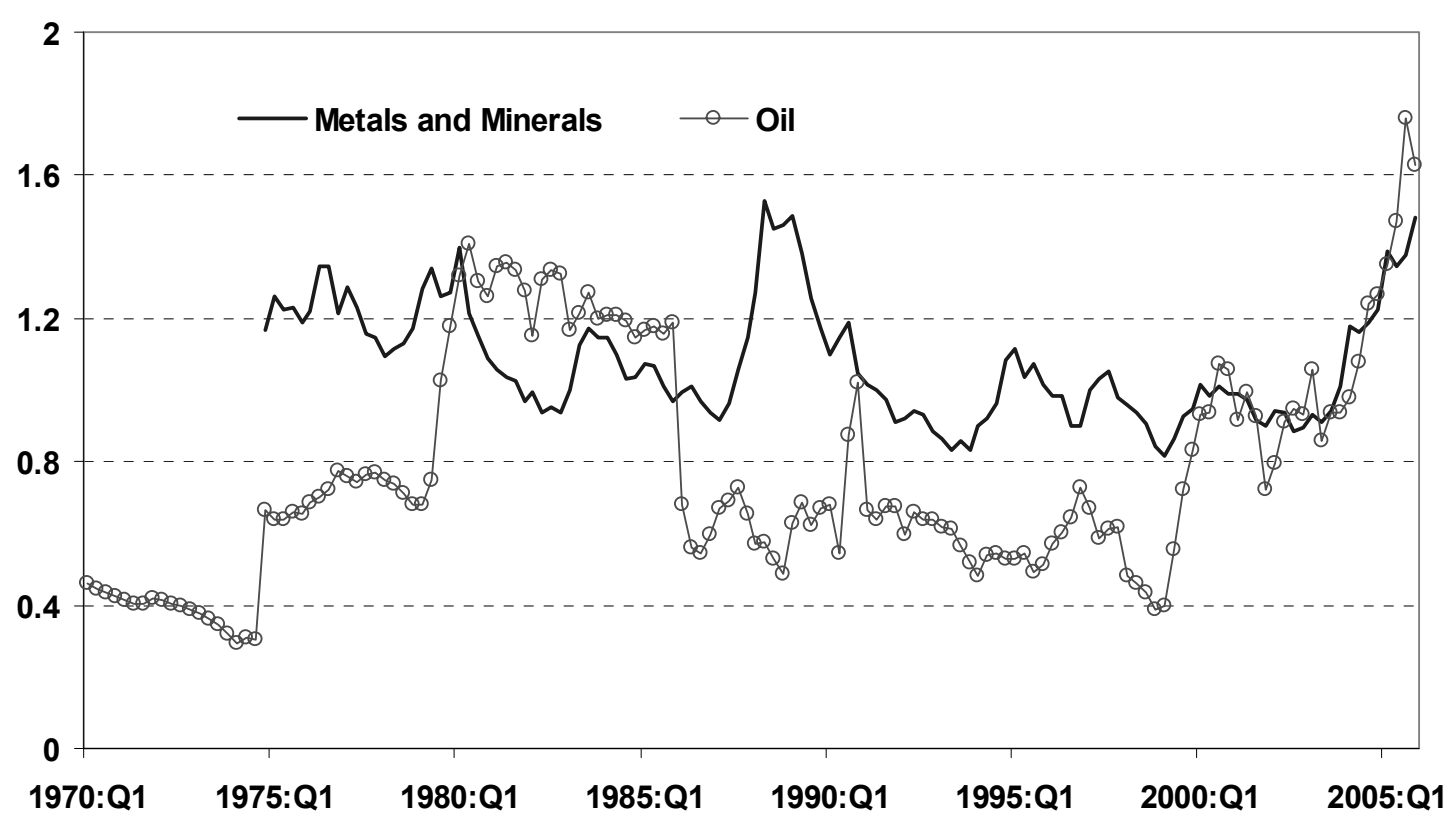

Source: OECD Economic Outlook database.

Figure 9b. Real agricultural prices

$2000=1$; deflated by world export prices in US dollar terms

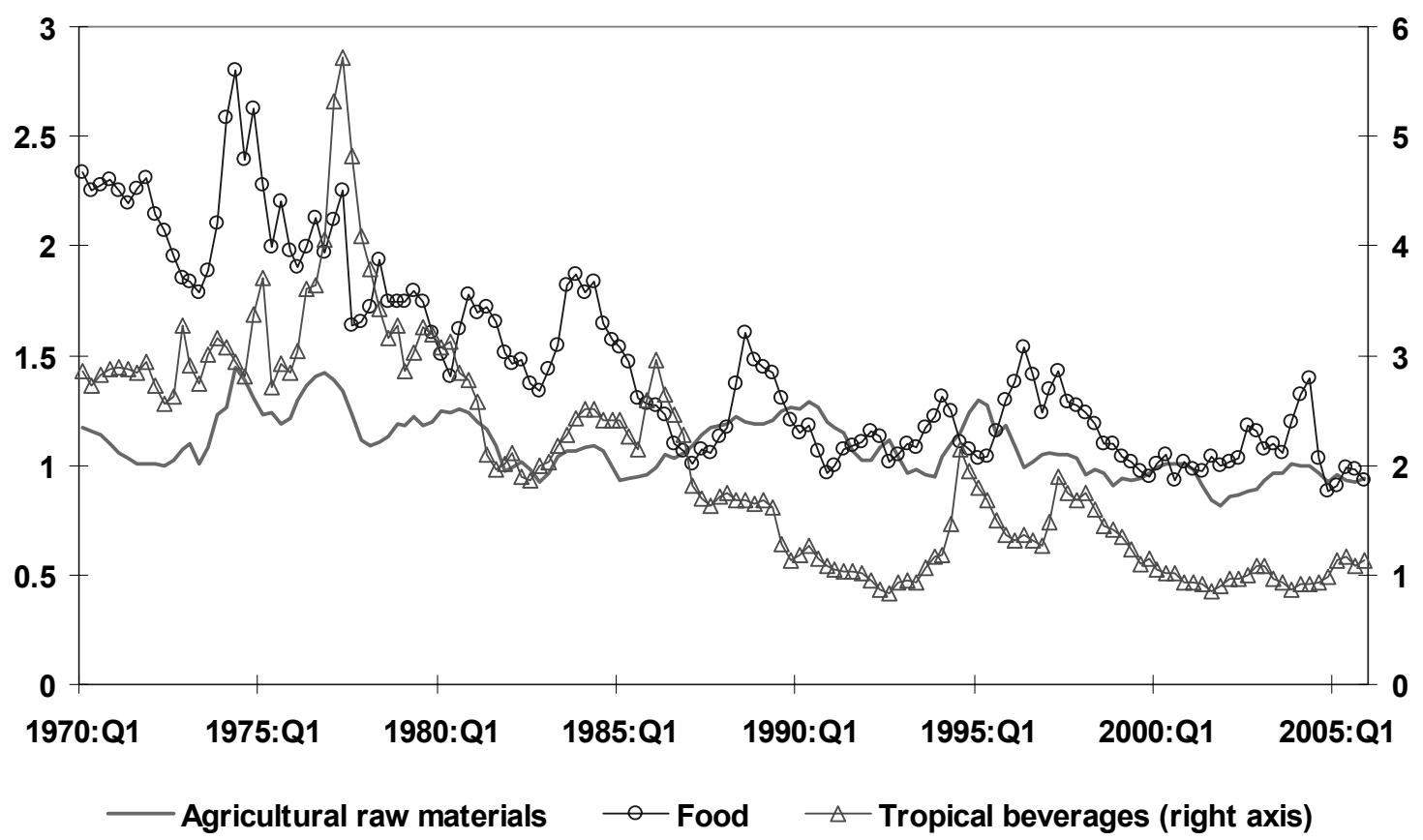

Source: OECD Economic Outlook database. 
17. Although this would appear to suggest that trade with lower-cost producers is placing downward pressure on domestic prices in OECD economies, the eventual effect on inflation is less clear. The calculations described in Box 1 are only ex-ante ones. The extent to which they eventually lead to lower consumer price inflation will depend on the effect they have on the behaviour of other competitors and domestically generated inflation. ${ }^{12}$ The latter will depend on whether the initial impacts are accommodated by the stance of monetary policy in the importing economy. Deflationary pressures on the general price level can, at least in principle, be offset eventually by monetary policy relaxation, although this does depend on the extent to which they are recognised, estimated accurately and acted upon promptly. ${ }^{13}$

18. Such estimates provide only a partial view of the effects on OECD economies of increased trade with lower-cost producers in Asia and elsewhere. In particular, there is no allowance for any offsetting effects of higher world commodity prices that may result from strong growth in comparatively commodityintensive economies such as China.

\section{Box 1. The impact of imports from emerging markets on inflation}

This Box illustrates the impact on inflation rates in the United States as a result of the increasing importance of lower-cost imports from emerging economies in domestic demand. The emerging economies considered here are China and other Dynamic Asia, the latter including Chinese Taipei, Hong Kong, Indonesia, Malaysia, the Philippines, Singapore and Thailand. A simple accounting framework is used, with the domestic demand deflator assumed to be given by a weighted average of the prices of goods produced by higher-cost domestic manufacturing producers (denoted $\mathrm{C}^{\mathrm{M}}$ ) and the prices of goods imported from emerging economies (denoted $\mathrm{C}^{\mathrm{E}}$ ). This is shown in equation [A1], with $S$ representing the share of imported goods in total domestic demand.

$$
\ln \left(P_{t}^{M}\right)=S \ln \left(C_{t}^{E}\right)+(1-S) \ln \left(C_{t}^{M}\right)
$$

Using this relationship, the rate of change in the domestic demand deflator can be broken down into three subcomponents - an import penetration effect, a relative inflation effect and the change in prices in domestically produced goods. The resulting equation for inflation is denoted [A2]:

$$
\frac{\Delta P^{M}}{P_{t-1}^{M}}=\Delta S\left(\frac{C_{t}^{E}-C_{t}^{M}}{C_{t}^{M}}\right)+S_{t-1}\left(\frac{\Delta C^{E}}{C_{t-1}^{E}}-\frac{\Delta C^{M}}{C_{t-1}^{M}}\right)+\frac{\Delta C^{M}}{C_{t-1}^{M}}
$$

The first term in [A2] is the import penetration effect, representing the impact of changes in $S$ for a given initial relative price differential. The second term is the relative inflation effect, allowing for the impact of differences in the inflation rates of domestic and foreign producers at a given level of import penetration. The final term is the inflation rate of domestic producers, which includes the possible response of mark-ups to the emergence of lower-cost competitors. This last term is not considered in the calculations in this Box, although it is incorporated in the estimated inflation equations in Annex 2.

The calculations should be regarded as illustrative rather than a precise estimate of the impact of rising imports from low cost producers. They are sensitive to the period considered, given the rapid rise in import penetration by emerging economies over the past few years, and the decomposition employed is not unique. They also rely on the accuracy with which the initial price level differential between the importing and exporting economies is observed. The calculations here use price level differentials for China and Dynamic Asia in 1995, based on those reported in Motohashi (2006). A longer-term price level profile for China and the other Asian economies was obtained using export price series for China and dynamic Asia from the OECD Economics Department's Analytical Database.

12. Kamin et al. (2006) find little evidence that the rising share of Chinese goods in the United States has had a marked impact on producer price inflation.

13. To this extent, domestically generated inflation may end up being higher than otherwise. In this sense, the impact of higher trade with low-cost producers is inflationary (Rogoff, 2006). 
The results are reported in the table below. During the period from 1996 to 2000, imports from China are estimated to have mechanically deducted 0.1 percentage point per annum from inflation in the United States. In contrast there is little discernible effect in the euro area. But since 2000 , imports from China are estimated to have made a negative contribution to inflation in the euro area, deducting 0.2 percentage point per annum from inflation on average. For the United States, the negative contribution of imports from China to inflation since 2000 is similar to that in the previous five-year period.

While generally smaller, a similar pattern can be inferred for the contributions of imports from dynamic Asia on inflation. Since 2000 , such imports are estimated to have reduced inflation in the euro area by 0.1 percentage point per annum, but have had little noticeable impact in the United States. One difference with China is that the impact of imports from dynamic Asia is primarily driven by the inflation differential term in [A2], rather than the import penetration term.

It is clear, even from these results, that trade with lower-cost economies can have different effects in particular importing economies, not just in terms of the magnitude of the effects, but also in the channels through which they arrive. The results for the euro area also suggest that the downward pressure from lower-cost economies may have accelerated since the year 2000 , in at least some economies.

Computing the mechanical globalisation impact on inflation: results

\section{Percentage points}

\begin{tabular}{|c|c|c|c|c|c|c|c|}
\hline & \multicolumn{3}{|c|}{ A. Imports from China } & \multicolumn{3}{|c|}{ B. Imports from other dynamic Asia } & \multirow{2}{*}{$\begin{array}{l}\text { Total } \\
\text { A }+ \text { B }\end{array}$} \\
\hline & $\begin{array}{c}\text { Import } \\
\text { penetration }^{\text {effect }}{ }^{1}\end{array}$ & $\begin{array}{l}\text { Imported } \\
\text { inflation } \\
\text { effect }^{2}\end{array}$ & $\begin{array}{l}\text { Total } \\
\text { effect }\end{array}$ & $\begin{array}{c}\text { Import } \\
\text { penetration }^{\text {effect }}{ }^{1}\end{array}$ & $\begin{array}{c}\text { Imported } \\
\text { inflation }^{2} \text { effect }^{2}\end{array}$ & $\begin{array}{l}\text { Total } \\
\text { effect }\end{array}$ & \\
\hline \multicolumn{8}{|c|}{ United States } \\
\hline 1991-1995 & -0.04 & 0.02 & -0.02 & -0.02 & 0.01 & -0.01 & -0.03 \\
\hline $1996-2000$ & -0.04 & -0.04 & -0.09 & 0.00 & -0.04 & -0.04 & -0.12 \\
\hline 2001-2005 & -0.12 & 0.00 & -0.11 & 0.03 & -0.03 & 0.00 & -0.11 \\
\hline \multicolumn{8}{|l|}{ Euro area } \\
\hline 1991-1995 & -0.03 & 0.01 & -0.02 & -0.01 & 0.00 & -0.01 & -0.03 \\
\hline $1996-2000$ & -0.02 & 0.02 & 0.00 & 0.00 & 0.05 & 0.05 & 0.05 \\
\hline 2001-2005 & -0.13 & -0.06 & -0.19 & -0.02 & -0.07 & -0.09 & -0.28 \\
\hline
\end{tabular}

\subsection{Estimates of the direct impact of imports from the non-OECD on OECD import price inflation}

19. The above results are broadly comparable with those reported in other recent studies of the impact of the switch of sourcing to low-cost countries, although most of these other studies consider the impact on trade prices in the importing country rather than on consumer prices. For the United Kingdom, estimates suggest that the move to low-cost producers during the period 2000-04 reduced the rate of world export price inflation to the United Kingdom ${ }^{14}$ by 0.55 percentage point per annum on average (Nickell, 2005). ${ }^{15}$ For the United States, Kamin et al. (2006) estimate that the growing share of imports from China lowered import price inflation by around 0.8 percentage point per annum on average between 1993-2002,

14. World export prices are a weighted average of the export prices of those countries that export to the United Kingdom is US dollars.

15. Related findings for Norway, Sweden and New Zealand are reported by Melick and Galati (2006) and Hodgetts (2006). 
all else being equal. The direct impact of this on consumer price inflation during this period would have been small, at around 0.1 percentage point or less, similar to the estimates in Box $1 .{ }^{16}$

20. Over the decade 1993-2002, only Japan and Korea are estimated to have experienced a similar reduction in import prices as that in the United States as a result of trade with China (Kamin et al., 2006). For the median OECD economy, import price inflation is estimated to have declined by only 0.13 percentage point per year on average. Many of these economies, especially those in Europe, have a smaller share of their trade with Asian economies than the United States and Japan do. On the other hand, these economies are likely to have received additional benefits from low-cost imports from other economies, especially those in Central and Eastern Europe, and the size of any effect is likely to have become larger in more recent years due to the further rapid increase in import penetration by lower-cost producers.

21. The ex-ante effects of low-cost production on trade prices are likely to be concentrated in particular sectors of the economy. Using data for the euro area from 1995 to 2005, estimates produced by the European Central Bank indicate that the combined impact of the rising import penetration of low-cost producers in the manufacturing sector, and the differentials in inflation between them and other producers, has dampened euro area manufacturing import price growth by approximately 2 percentage points per annum (ECB, 2006). In contrast to the studies discussed above, these calculations also include an allowance for the impact of production in regions other than Asia. ${ }^{17}$ Feyzioğlu and Willard (2006) find that the impact of trade with China on inflation in the United States and Japan is relatively strong on particular items such as household furnishings and food, rather than on the general consumer price level.

22. Overall, it appears reasonable to conclude that rising levels of imports from all lower-cost producers will have acted directly to reduce non-commodity import price inflation by up to 1 to $2 \%$ per annum in most OECD economies over the past decade, with globalisation-related effects in goods prices also being reflected in some services prices as well. To date, there have been no studies of the impact of service sector offshoring on the prices of imported services in the OECD economies. Some possible evidence on this is provided in Figure 10, which shows import price deflators from the United States national accounts. Up until the early-1990s the price of imported business services, a category which will include imported services that were moved offshore from the United States, rose faster than the prices of other service imports. But since that time, prices of business service imports have broadly stagnated whereas those of other service imports have continued to rise, suggesting that a globalisation effect may be present. $^{18}$

16. Thus implicitly, the findings in Box 1 can be regarded as consistent with a view that trade with China and the other Dynamic Asian economies will have been lowered import price inflation in the United States and the euro zone by at least $1 \%$ per annum.

17. The group of "low-cost" producers considered in ECB (2006) includes the new member states and candidate countries of the EU, the CIS, Latin America, Africa and all Asian countries other than Japan.

18. Business services prices are measured using the deflator for imports of "other private services" in the United States national accounts. 
Figure 10. Goods and services import prices in the United States

US Import Prices $(2000=100)$

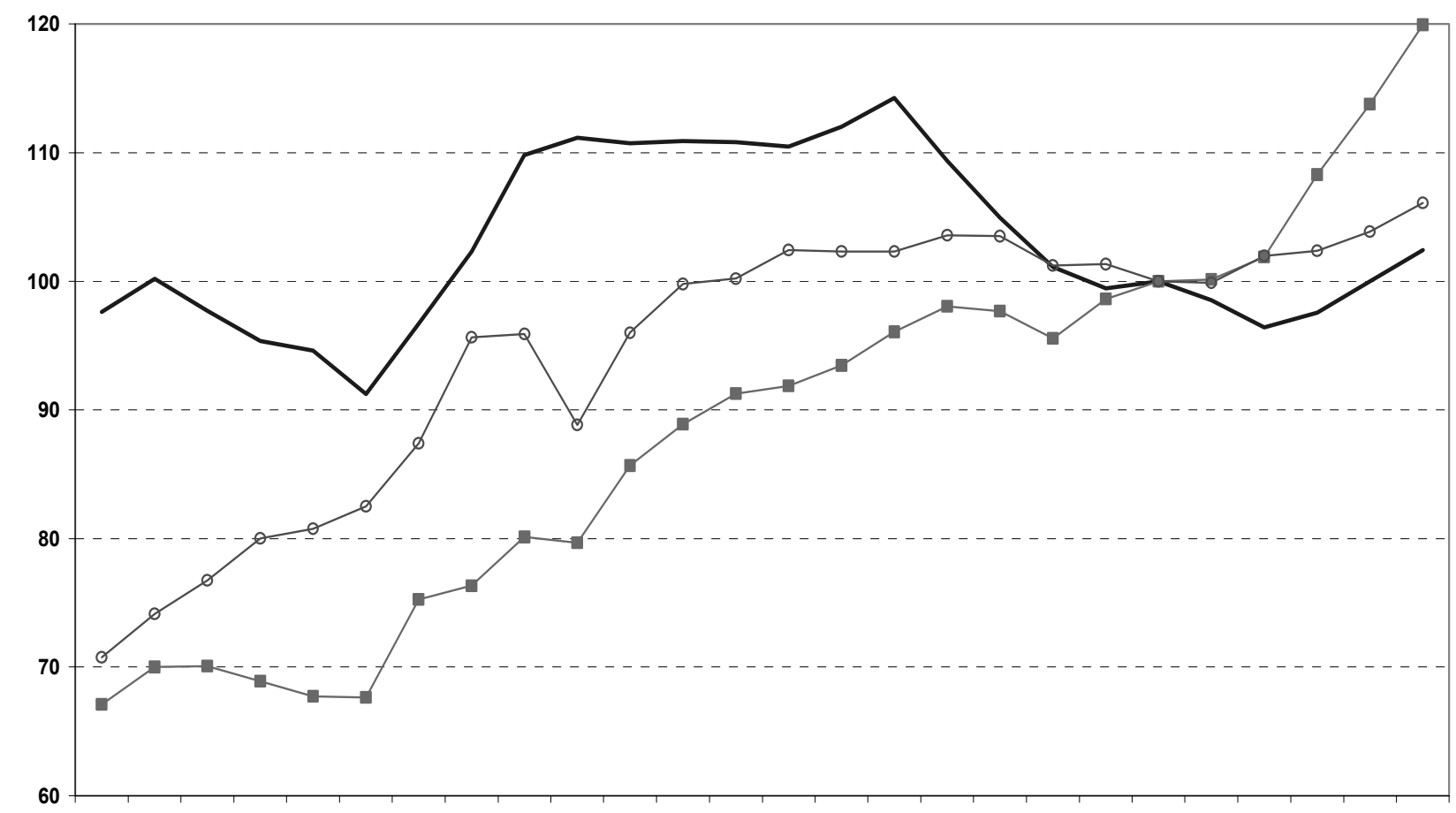

19801981198219831984198519861987198819891990199119921993199419951996199719981999200020012002200320042005

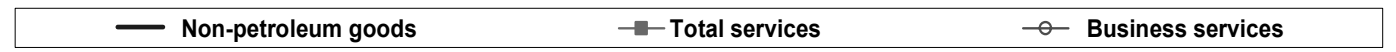

Source: Bureau of Economic Analysis, United States.

23. Changes in the domestic price level that stem from developments in only a few sectors of the economy may be less likely to generate a monetary policy response than equivalent changes in the domestic price level that are widespread throughout the economy (Rogoff, 2006). If so, the initial impact of an appreciation in the terms of trade (due to declining import costs) may be to push inflation below the medium-term target trajectory of the monetary authorities. ${ }^{19}$ The extent to which it does so, and the time over which this is allowed to persist, will depend not only on the behaviour of import prices but also on whether there are adverse effects on policy credibility and inflation expectations (Bean, 2006).

\section{The impact of non-OECD output growth on commodity prices}

24. Strong growth in China and other emerging markets in recent years has coincided with a sizable increase in global commodity prices. This section examines the extent to which these developments are related by assessing the linkages between macroeconomic conditions, including the relatively higher rate of growth in non-OECD economies, and oil and non-oil commodity prices. On the basis of new "reduced form" equations for a selection of commodities, calculations are reported of what might have happened to

19. Equally, the initial impact of a depreciation in the terms of trade brought about by rising prices of imported commodities may push inflation above the medium-term target of the monetary authorities. 
commodity prices over the past five years if the non-OECD economies had not grown faster than the OECD economies. Such calculations, although only illustrative, help to evaluate the impact of growth in emerging markets on commodity prices and may thereby also help to indicate whether prices will continue to rise beyond the current high price levels or whether these are only temporary.

\subsection{Demand growth in the non-OECD}

25. Earlier periods of rapid growth in real oil prices in the mid and late 1970s were characterised by marked constraints on oil production, notably by producers in OPEC. In contrast, the present upturn in oil prices has occurred at a time when the growth rates of both oil consumption and oil production have accelerated (IEA, 2006, Table 1). Over the decade to 2001 global oil demand rose by $1.4 \%$ per annum on average. In the subsequent four years demand growth accelerated to an average $2 \%$ per annum.

26. The acceleration in global demand is more than accounted for by developments in non-OECD economies, where demand growth accelerated to just under 4\% per annum on average from 2001 to 2005 , after averaging $1 \frac{1}{2}$ per cent per annum in the previous decade. In China, average annual demand growth rose from just under $6 \frac{1}{2}$ per cent to just below 9\% per annum. By 2005 the non-OECD economies accounted for $40 \%$ of total global oil consumption, with one-fifth of this being due to China (Figure 11). ${ }^{20}$

27. The acceleration in oil demand in the non-OECD economies in recent years reflects in part strong output growth, especially in industrial sectors, a higher level of energy consumption per unit of output than the average OECD economy (OECD, 2005; Markandya et al., 2006) and rising private usage of motor vehicles. Strong world trade growth may also have contributed because of the associated growth in demand for aviation and shipping transportation.

28. Although the growth in final demand for oil would appear to have been the primary factor behind the recent rise in oil prices, this need not mean that other factors have been absent. Almost certainly there has been increasing precautionary and speculative demand as well, with concerns about possible supply disruptions in the Middle East and the possibility of short to medium-term supply shortages because of low rates of past investment and natural disasters all acting to raise risk premia. Speculation may also have played a role (IMF, 2006b).

29. The non-oil commodity group contains a wide range of different commodities, with few common elements in their prices. Metals and, to a lesser extent, agricultural raw materials are the most likely to be affected by a rise in the level of activity in commodity-intensive economies, as well as by the business cycle. China has also been a significant influence behind the strong global growth in demand for many metals over the past few years. During the period 2002-05, the growth in demand from China accounted for almost all of the increase in global demand for nickel and tin, and over half of the increase in demand for aluminium, copper and steel, reflected in marked increases in the share of China in total global consumption (Figures 12 to 14 ). ${ }^{21}$

20. Insofar as certain commodity-intensive activities have moved from other countries (including OECD countries) to China, the growth of Chinese demand for commodities may give an exaggerated impression of the net impact on demand for commodities of the emergence of China. For this reason, total non-OECD output measures are used in the empirical work, rather than just measures for China.

21. Although China and other emerging markets also make a significant contribution to global demand for other agricultural commodities (IMF, 2006b), the speed of response in supply can act to offset the impact of demand pressures on prices. Observed prices may also rise rapidly for reasons unconnected to demand pressures, such as weather-related supply fluctuations. 
Figure 11. Oil consumption, 1995 and 2005

Per cent share of global total

1995

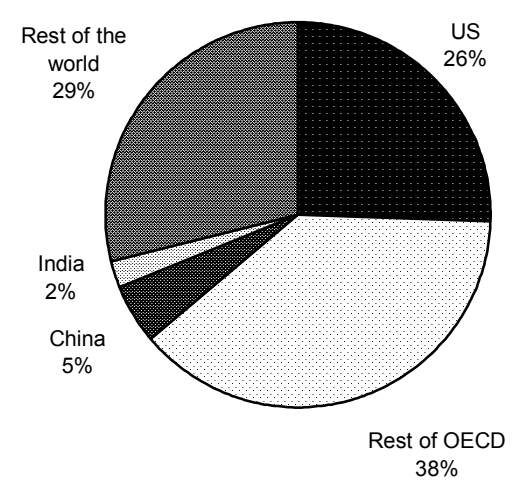

2005

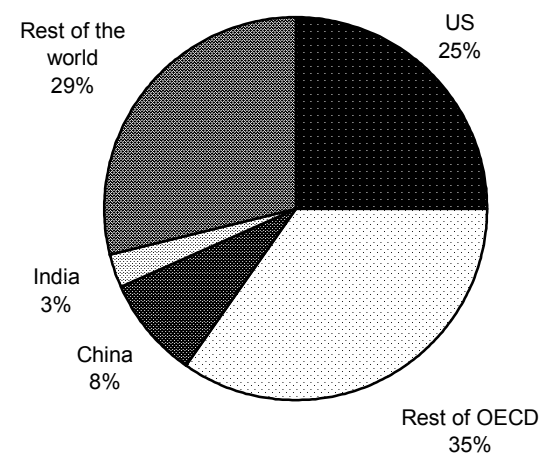

Source: International Energy Agency.

Figure 12. Consumption of aluminium, 2002 and 2005

Per cent share of global total

2002

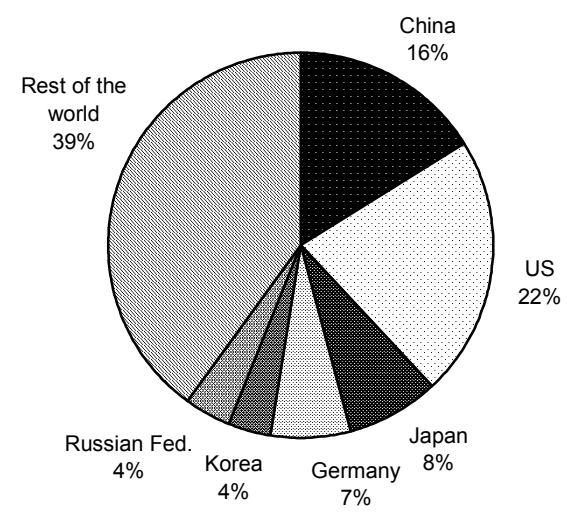

2005

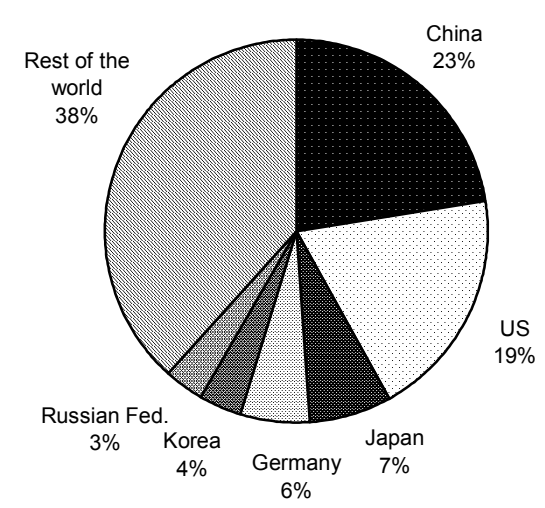

Source: World Bank and World Metal Statistics. 
Figure 13. Consumption of copper, 2002 and 2005

Per cent share of global total

2002

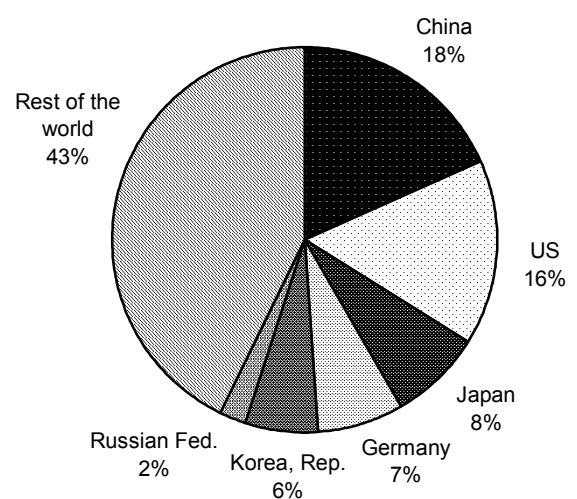

2005

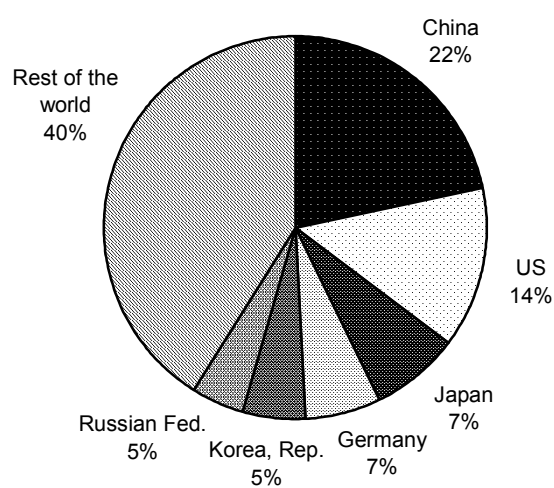

Source: World Bank and World Metal Statistics.

Figure 14. Consumption of nickel, 2002 and 2005

Per cent share of global total

2002

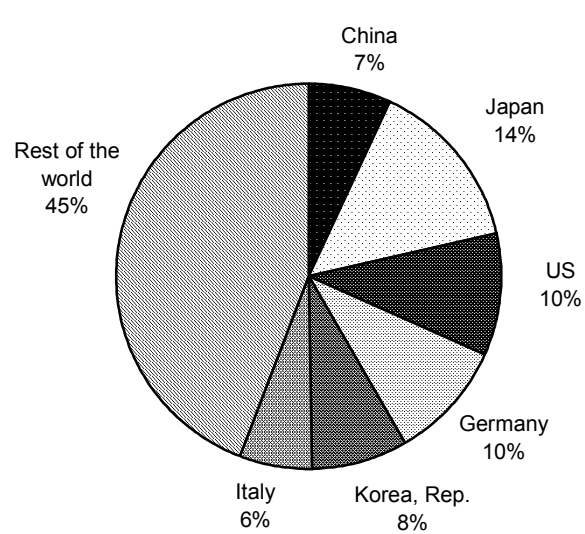

2005

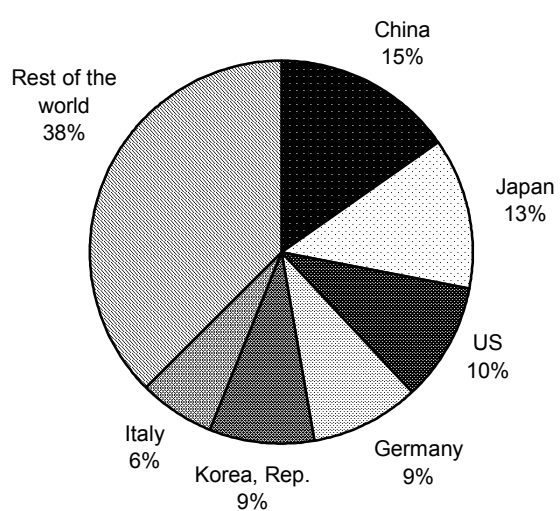

Source: World Bank and World Metal Statistics. 


\subsection{Estimates of the impact of output growth on commodity prices}

30. To obtain a more precise estimate of the impact of the recent rapid output growth in the nonOECD countries on commodity prices, reduced-form price equations have been estimated for five main commodity groups (oil, metals and minerals, agricultural raw materials, food and tropical beverages). These relate real prices to measures of the level and growth of global activity, as well as measures of the share of world trade and world GDP accounted for by non-OECD economies. ${ }^{22}$ Measures of the global output gap, and output gaps in the OECD and the non-OECD economies were also included in the analysis. It is well established that the global output gap is an important factor behind the cyclical behaviour of commodity prices, especially when output growth is above potential (Adams and Ichino, 1995; Rae and Turner, 2001). The historical profile of the global output gap is shown in Figure $15 .^{23}$

Figure 15. The world output gap

Deviations of actual GDP from potential GDP as a per cent of potential GDP

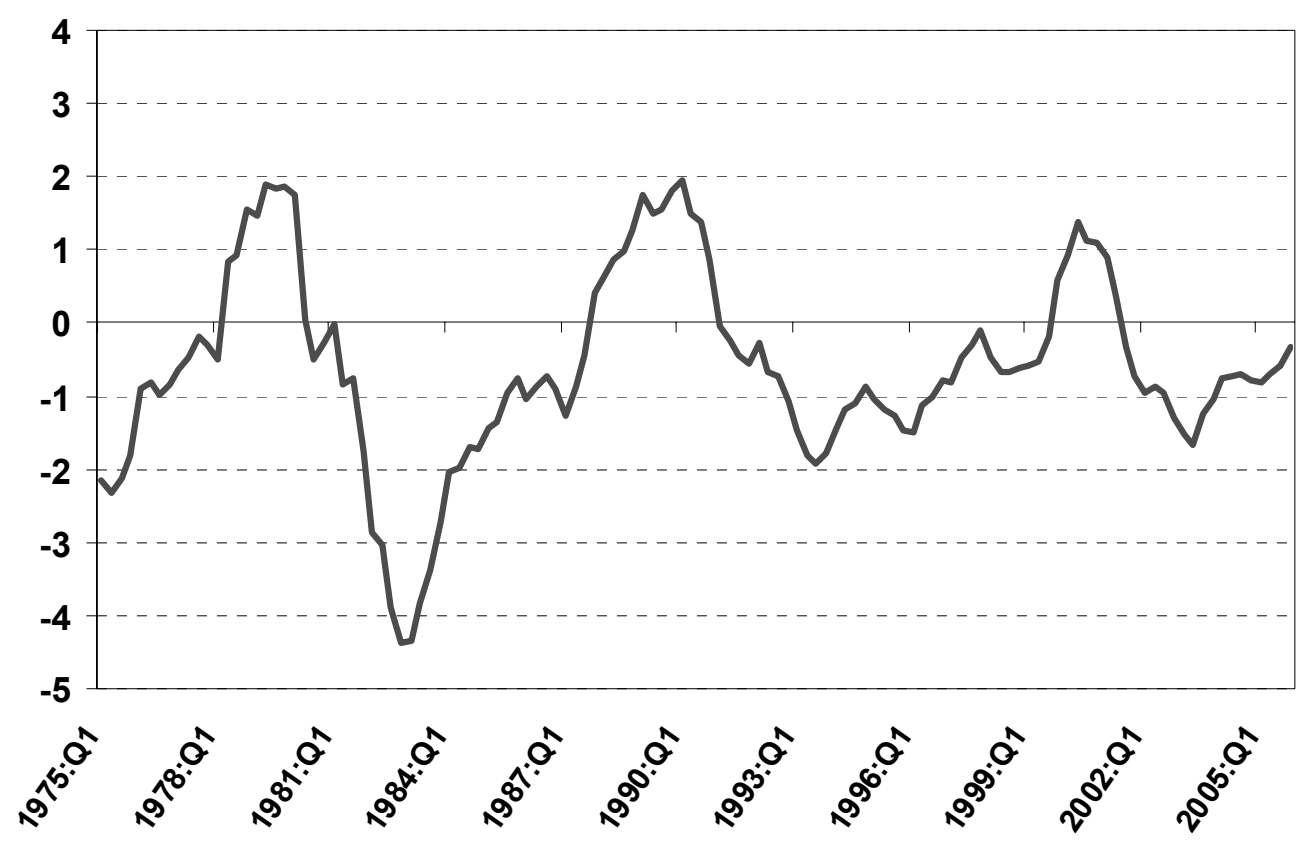

Source: OECD estimates.

22. A broader set of control variables were also considered initially for other possible macroeconomic influences, such as the US effective exchange rate and real short-term interest rate. All these factors have been found to be important influences on commodity prices in earlier studies (Adams and Ichino, 1995; Hua, 1998).

23. The global output gap used in estimation is a GDP weighted average of separately estimated output gaps for the OECD and the non-OECD economies. The OECD output gap is calculated using a production function approach to assess potential output. The non-OECD output gap was derived using a measure of potential output derived from a Hodrick Prescott filter. 
31. The econometric estimates reported in Appendix 2 provide significant empirical evidence that the present upturn in real oil and metals prices has been amplified by the rapid output growth in emerging markets. For oil, there is a choice between two statistically similar equations, as shown in Table A2.1. In the first, the effects of strong growth in the non-OECD economies work through the levels term in world GDP and through a dynamic term in the share of the non-OECD economies in the level of world trade. A limitation of this equation, estimated over a sample from the mid-1980s to 2005, is that the long-run income elasticity is very high, almost certainly reflecting the strong growth in oil demand and real oil prices over the estimation sample.

32. The recent impact of strong growth in the non-OECD is tested directly in the second equation in Table A2.1 by including the differential between the rates of GDP growth in the non-OECD and the OECD starting in 2001. The coefficient on this term is both positive and statistically significant. Incorporating the additional measure also causes the long-run income elasticity to halve, although it remains significantly different from zero (at the $10 \%$ level). ${ }^{24}$

33. For metals prices in real terms, recent demand-related pressures were also found to be best reflected by the differential between the rates of GDP growth in the non-OECD and the OECD (see Figure 6). In effect, this corresponds to the rate of change of the non-OECD share of world GDP. The level of world GDP and the non-OECD trade share measure were not found to be significant determinants of metals prices. No significant effects from any of these variables were found for the three agricultural commodity prices either. The differences between these findings and those for oil prices are likely to stem from supply being more elastic for non-oil commodities, with any initial increase in demand more rapidly offset by an expansion in supply.

34. An implication of these results is that a period in which growth in the non-OECD economies is faster than that in the OECD economies will ultimately have only a temporary positive impact on the level of real metals prices. In contrast, the impact on real oil prices will be permanent because the higher level of global GDP that results is implicitly taken to imply a permanent increase in the level of oil demand with supply being less than fully elastic. In practice it seems unlikely that the longer-term difference in the impact on metals and oil prices would be as pronounced as this, even if such a feature is present in the comparatively short sample used for estimation.

35. Fluctuations in output gaps are also found to have a significant short to medium-term influence on each of the commodity prices, although there are marked differences in the size and direction of the effect on individual commodities. An increase in global output relative to trend is found to raise initially the real price of each commodity group. This change quickly fades for the prices of food and tropical beverages, but is found to persist for several years for oil prices and, to a lesser extent, metals and agricultural raw materials prices. For oil prices, the impact of an increase in the global output gap is found to be larger if it coincides with an increase in the non-OECD output gap, consistent with what might be expected given the different industrial structures in the OECD and the non-OECD.

\subsection{Estimates of the impact of non-OECD growth on commodity prices}

36. In order to quantify the impact of the strong growth in the non-OECD economies on commodity prices in recent years the econometric equations were simulated under two assumptions. Firstly, that the share of the non-OECD in world trade remained unchanged from the average level in the year 2000, and

24. Significant econometric results for oil prices could be obtained only when using a sample beginning in the mid-1980s. The findings were inconclusive when the estimation period was lengthened by including the acceleration in oil prices in the 1970s. One possible explanation for this is that supply-side factors were the dominant influence on prices in these earlier periods. 
secondly that GDP in the non-OECD economies grew only at the rate of OECD GDP from 2000. The resulting calculations of the change in prices are only suggestive, but serve to illustrate the possible orders of magnitude involved. As the non-OECD share of world trade and GDP rose throughout the period from 2001-05, the alternative path implies an increasingly large divergence from the actual outturn. ${ }^{25}$ As a result, the impact on real prices of the change also increases in size over time.

37. For oil prices, the impact of holding the non-OECD trade share fixed at its level in 2000, and letting non-OECD GDP grow in line with OECD GDP, is to bring about a decline relative to baseline of just over $40 \%$ in the level of the real oil price by the end of 2005 (Figure 16a) when using the second oil price equation in Table A2.1. In nominal terms this is equivalent to a decline to just under $\$ 35$ per barrel in the price of oil in the fourth quarter of 2005. Although this represents a sizable difference from the actual outturn, it does not entirely remove the strong growth in oil prices in recent years, as can be seen from Figure 17b. In the alternative equation without the extra variable for the growth differential from 2001, the real oil price was lowered by some $20 \%$ by the end of 2005 from its baseline level.

38. For metals prices, corresponding estimates are also based on the assumption that GDP in the nonOECD economies grew at the rate of OECD GDP from 2000. The resulting changes in the profile of metals prices are smaller than for oil prices, with the real metals price being about $10 \%$ lower by the fourth quarter of 2005 than would otherwise have been the case. This accounts for only a small fraction of the actual growth in metals prices in recent years (Figures 17a and 17b).

39. The alternative profile of oil prices also has a small impact on the prices of agricultural raw materials, reducing these prices by between $1-1 \frac{1}{2}$ per cent over the course of 2003-05 in the scenario in which oil prices declined by just over $40 \%$ by the end of 2005 . The prices of food and tropical beverages remain unchanged.

40. Other analytical studies have also suggested that strong output growth could have a sizable effect on commodity prices. A related scenario for future oil demand in China is considered in CBO (2006), with oil demand in China from 2006 to 2010 rising by 71/2 per cent per annum, similar to the rate seen from 2000 to 2005 . This is estimated to be associated with an increase of $\$ 14$ per barrel in real oil prices, which would be equivalent to an increase of almost $25 \%$ on the average price of a barrel of Brent crude oil in 2005. Adams and Ichino (1995) estimate that a sustained rise of 0.5 percentage point in the annual rate of growth of world GDP is associated with increases of almost 12 and $10 \%$ in real oil and metals prices respectively, after six years.

41. The scenario analysis of the impact of reduced levels of activity in the non-OECD economies does not consider short-term cyclical influences on prices, with world and non-OECD output gaps being left unchanged. However, if slower growth originated at least in part from the demand side, it could be argued that they should also weaken. ${ }^{26}$ In order to evaluate the sensitivity of commodity prices to cyclical changes in output gaps, a second set of scenarios were constructed in which the output gap was changed for a short period of time. Two alternative paths were considered -- a 2 percentage-point reduction in output lasting for one year and a 1 percentage-point reduction in demand relative to potential lasting for two years. As can be seen from Figure 16, both of these changes would imply relatively large movements in the world output gap compared with those seen in the past.

25. By the fourth quarter of 2005 , world GDP in constant prices is around $10 \%$ below its actual value as a result of allowing non-OECD GDP to grow at the rate of OECD GDP from 2000 onwards.

26. To this extent, the results reported above may suggest a slight underestimation of the effects on real commodity prices. 
Figure 16a. Removing the impact of non-OECD growth on real oil prices

Percentage deviations from baseline

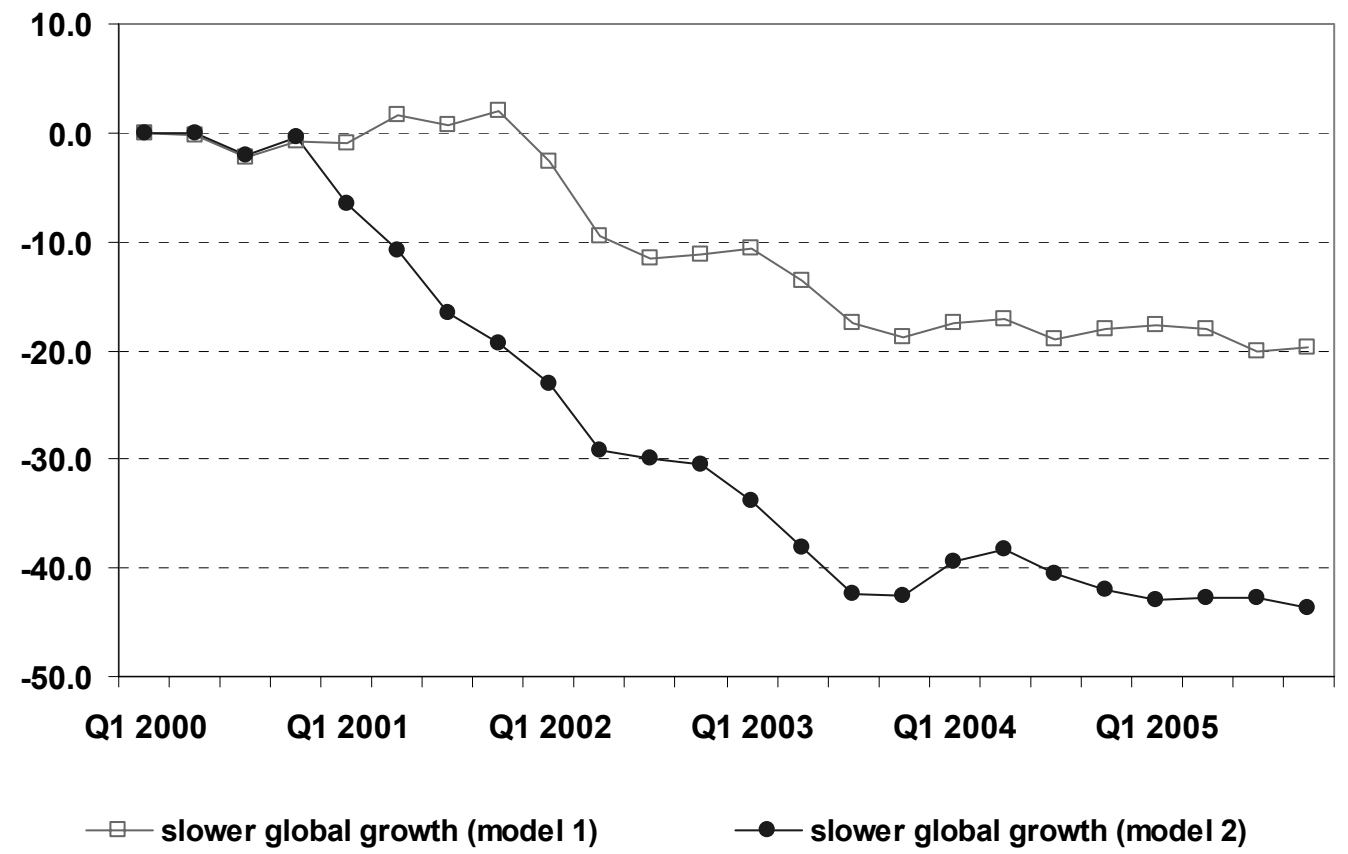

Figure $16 \mathrm{~b}$. The profile of real oil prices

\$ per barrel, 2000 prices

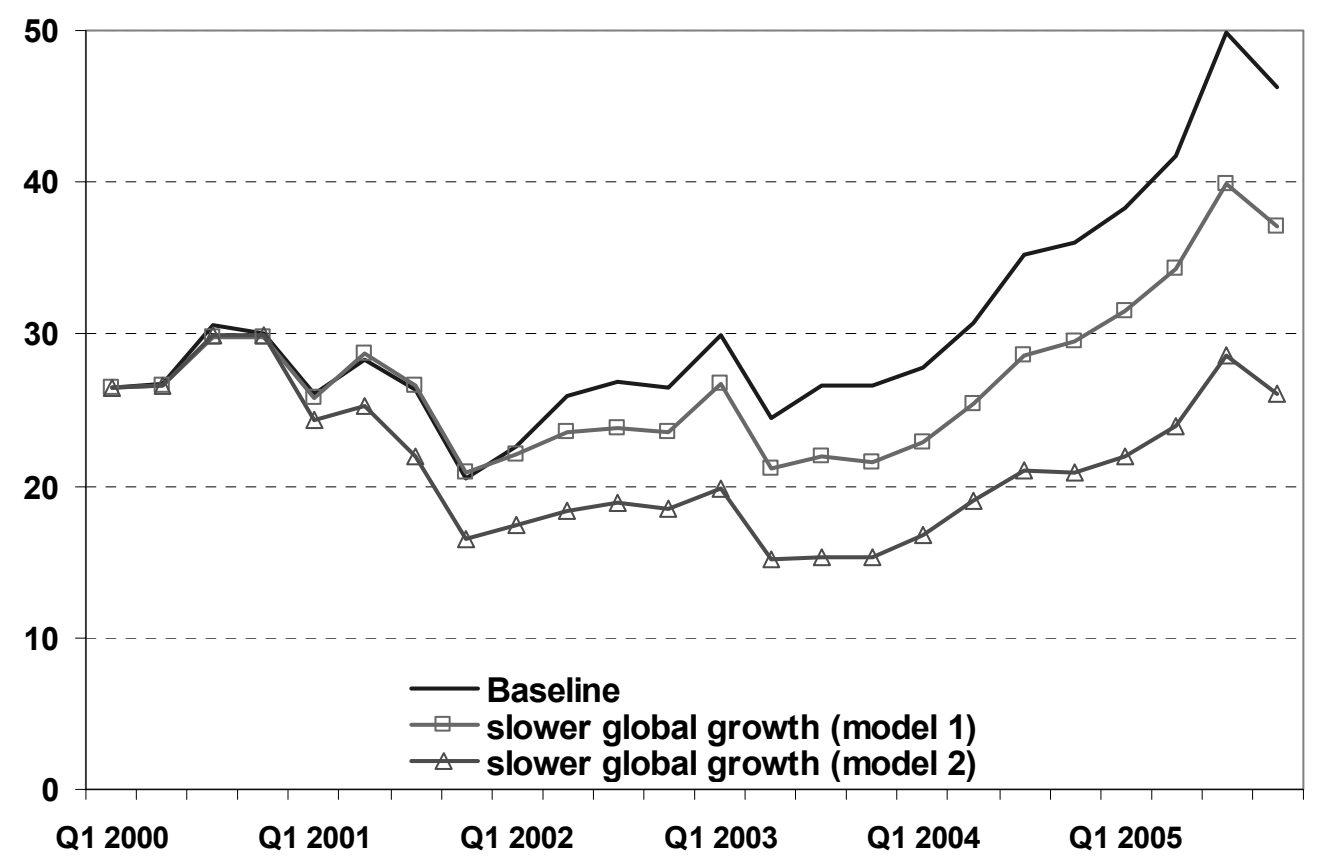


Figure 17a. Removing the impact of non-OECD growth on real metals prices Percentage deviations from baseline

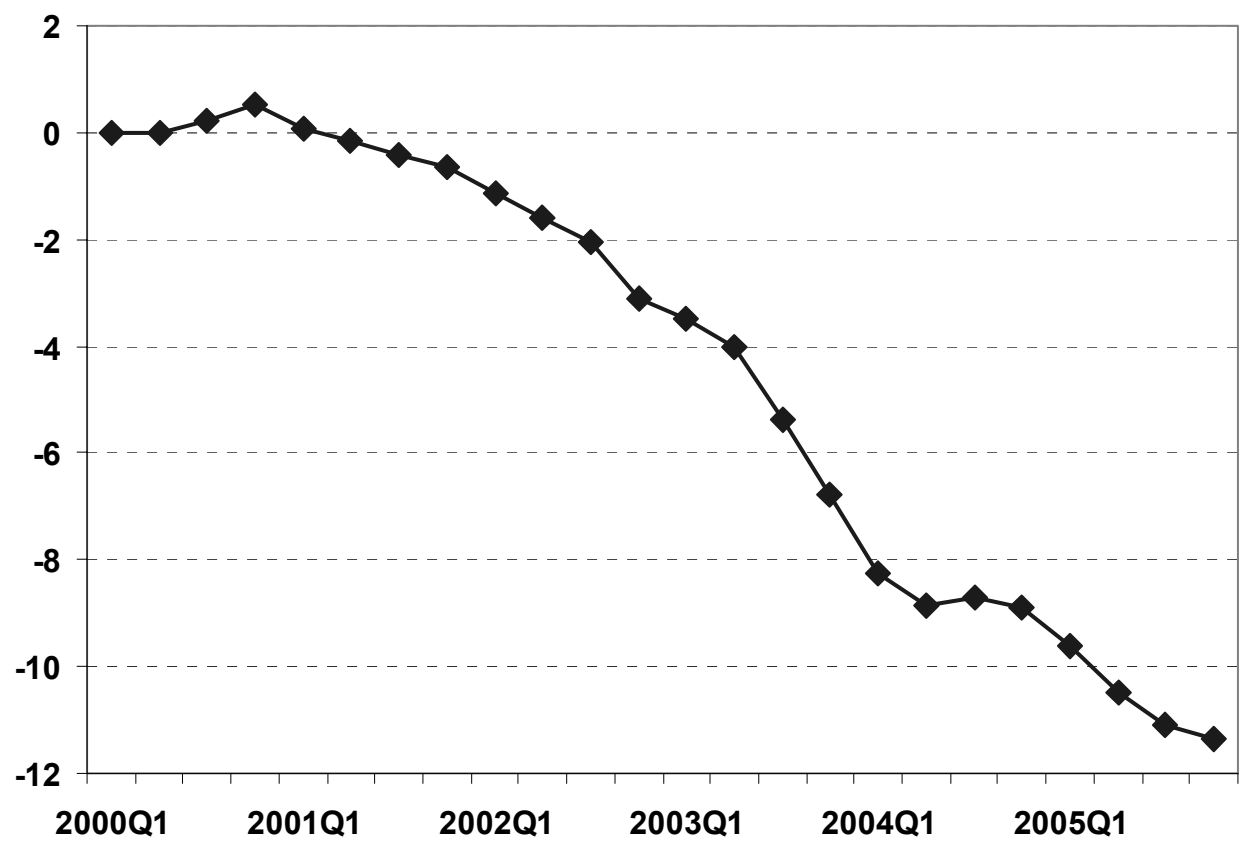

Figure $17 \mathrm{~b}$. The profile of real metals prices

$$
2000=1.0
$$

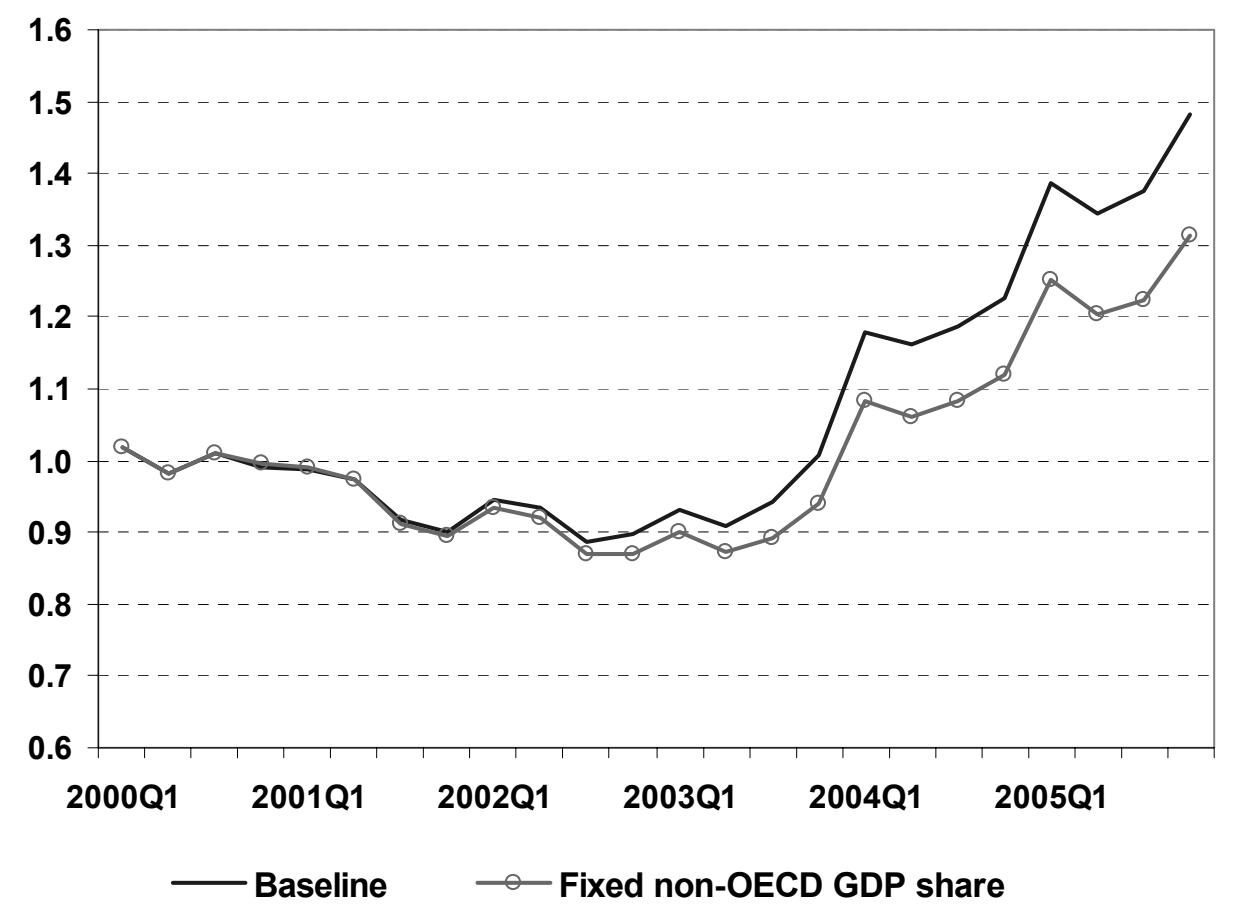


42. The results of this exercise, again holding world export prices and all other factors constant, also illustrate the different sensitivities of each real commodity price to cyclical influences. The largest and most persistent effect is on real oil prices, with prices reduced by up to $20-25 \%$ in the two scenarios, and returning back to their baseline levels only after five years. The real prices of agricultural raw materials and metals initially fall by up to 8 and $10 \%$ respectively, before rising and returning above the baseline level after two years, which is consistent with what might be expected in these markets as supply responds to the initial demand-driven reduction in prices. The real prices of food and tropical beverages initially decline by between 5 and $10 \%$ in the first year in which the output gaps are reduced, before rising above previous levels in the second year.

43. Overall, it is clear that the recent period of strong output and trade growth in the non-OECD economies and, by extension, the increasing internationalisation of production and offshoring from the OECD to the non-OECD economies, has placed significant upward pressure on the prices of many commodities. This is especially so for oil. The impact varies across commodities and has also built up over time. However, it is equally clear that growth in the non-OECD is not the only factor behind the recent acceleration in commodity prices, especially during $2005 .^{27}$

\section{The impact of globalisation on consumer price inflation}

44. This section provides an overview of the main findings from existing studies and then presents new results on the wider impact of globalisation on consumer price inflation in OECD economies based on new empirical results. This includes tests of whether inflation dynamics changed in the mid-1990s when the extent of globalisation began to increase ${ }^{28}$ Given that the determinants of domestic inflation process are found to have changed around that time, section 6 goes on to explore the size of the impact of globalisation by conducting a scenario analysis, which explicitly distinguishes between the impact via noncommodity and commodity import prices. The latter is taken from the analysis discussed in section 4 whilst the former reflecting the findings in the range of studies discussed in section 3.

\subsection{Existing studies of globalisation and inflation}

45. Although there is a sizable literature on the determinants of inflation in OECD countries (Melick and Gelati, 2006), only a few papers directly assess the impact of globalisation on inflation. Other studies find evidence of structural changes in the inflation process that may possibly be related to aspects of globalisation, but this is not tested explicitly.

46. Several general conclusions emerge from this literature. Firstly, imports from low-cost countries have contributed to lower domestic inflation via a direct accounting effect and an indirect effect, whereby lower cost imports put pressure on domestic producers in import-competing industries to lower their prices. The size of this indirect effect appears to be positively related to the intensity of foreign competition. Secondly, increased trade integration appears to have changed the intensity of the response of inflation to cyclical output fluctuations for OECD countries. With the prices of many domestic goods being increasingly determined by global demand and supply conditions, domestic inflation has become less

27. Tests for parameter stability on the estimated equations for oil prices and metals prices indicate that there is no significant instability over the period 2003-05 as a whole, although there is evidence of instability in 2005 alone, with the equation failing to track the full extent of the increase in oil prices. See Annex 3 for further details.

28. A discussion of the possible channels through which globalisation may have effected the inflation process can be found in Appendix 1, along with a brief review of the recent empirical evidence on these channels. 
sensitive to measures of domestic economic slack and more sensitive to measures of foreign economic slack. Thirdly, global competition is generally found to have reduced the extent to which exporting firms are passing through exchange rate changes into domestic currency prices. Finally, inflation persistence seems to have declined in many countries over the past decades, helped by greater central bank credibility. A more detailed overview of several recent studies is given below.

47. The existing literature also suggests that the results of these studies vary across countries and are sensitive to the sample period that is used. The general conclusions drawn in the previous paragraph do not necessarily apply to all OECD countries. In particular, the evidence of changes in inflation persistence and the relative influence of domestic and foreign economic conditions on inflation is sensitive to the countries included in the estimation sample. ${ }^{29}$ For these reasons, the empirical work below allows for the possibility of different coefficients across countries, rather than simply imposing common coefficients on all.

\subsubsection{Trade openness and inflation}

48. Several studies have examined the relationship between trade openness and the level of inflation both for the economy as a whole and for particular manufacturing industries. One approach has been to directly estimate the 'mechanical' impact of imported goods from lower-cost economies on inflation in the importing economies (Kamin et al., 2006; OECD, 2006). These studies are discussed in detail in Section 3 of the main paper. They typically find that lower cost imports place a modest, ex-ante downward impact on consumer price inflation, with a more marked impact on import price inflation. These effects are found to vary over time and across countries. More generally, the impact of enhanced trade openness on consumer price inflation has also been found to be sensitive to the countries included in the estimation sample. Typically, smaller estimates are found for developed economies than for developing ones (Temple, 2002; Wu and Lin, 2006).

49. The impact of globalisation on inflation is explored in IMF (2006a), using a Philips curve framework in which current inflation is related to lagged inflation, import price inflation, the change in the oil price, and the output gap. To account for the impact of globalisation, interaction terms are introduced, with past inflation being interacted with a measure of monetary credibility, import price inflation being interacted with import penetration, and the output gap being interacted with openness, monetary credibility, average inflation, and a wage bargaining index. The model is estimated for a panel of eight countries (the G7 countries and Australia) over the period 1960 to 2004. The sensitivity of inflation to the domestic output gap is found to have fallen over the sample period. ${ }^{30}$ The key factor behind this decline is found to be trade openness. In general, import prices are found to have only a small influence on domestic inflation. Although a fall in import prices drives down consumer price inflation initially, the effect vanishes after about two years.

50. A number of studies have shown that industry-level price inflation is significantly related to measures of import competition (Gamber and Hung, 2001; Chen et al., 2004; IMF, 2006a). Gamber and Hung (2001) relate price inflation in 44 industries in the United States to import price inflation and an interaction term between import price inflation and industry-level import penetration, which is a measure of the intensity of foreign competition. Both terms are found to have statistically significant coefficients, suggesting that the impact of import price on domestic prices is positively related to the intensity of foreign competition. In a related study using data for a sample of manufacturing industries in seven European Union member states, Chen et al. (2004) estimate that the observed increase in openness over the sample

29. See, for instance, the different findings for each of six OECD economies in Debelle and Wilkinson (2002).

30. For 2004, the estimation results imply an inflation-output elasticity of 0.2 compared with a value of 0.3 for 1960 and 1983. 
period reduced industry mark-ups by 1.6 percentage points on average. ${ }^{31}$ Although the impact of the markup and productivity effects at the sectoral level is marked, reducing inflation by 0.3 percentage point per annum on average in the industries concerned, the impact is minimal at the economy wide level.

51. The determinants of changes in producer prices for 16 manufacturing industries in 11 OECD countries are also explored in IMF (2006a). It is found that changes in relative producer prices in a certain sector (measured by the deviation of producer prices in that sector from average producer prices across all sectors) are negatively related to changes in that sector's exposure to globalisation as measured by its import-to production ratio. On average, a 1 percentage-point increase in the import-to-production ratio is estimated to reduce the relative producer price by $0.1 \%{ }^{32}$ The contribution of increased openness to lower inflation appears to be twice as strong in low-tech sectors as in high-tech sectors. Moreover, the impact has increased over time; about $40 \%$ of the decline in relative prices of the manufacturing sector since 1995 is explained by openness, compared with only $25 \%$ during the 1980 s and early 1990 s.

\subsubsection{The influence of foreign capacity on domestic inflation}

52. A number of studies have sought to test directly whether measures of foreign output gaps or capacity utilisation have a direct impact on domestic inflation. The findings from such studies have been mixed. For the United States, some have found little evidence that foreign capacity utilisation has a significant impact on domestic inflation (Corrado and Mattey, 1997; Tootell, 1998), but others have come to the opposite conclusion (Gamber and Hung, 2001). More recent multi-country studies also suggest that measures of foreign economic slack play an important role in explaining inflation dynamics in OECD countries (Borio and Filardo, 2006; Vega and Winkelried, 2004).

53. Borio and Filardo (2006) test whether the gap between headline and core inflation is related to measures of the global output gap. Using a sample of 16 OECD economies it is found that the global output gap is significant, with its inclusion reducing the significance of the domestic output gap. ${ }^{33}$ Moreover, a rolling regression exercise indicates that the importance of global measures of economic slack has risen over time. ${ }^{34}$ To some extent these findings are not surprising. The gap between headline and underlying inflation includes energy and food prices, where global conditions on commodity prices have an important influence on domestic pricing. As shown in Appendix 2 of this paper, estimates of the global output gap have a significant positive relationship with commodity price inflation.

54. A related approach to the possible link between global economic conditions and national inflation rates is pursued by Ciccarelli and Mojon (2005). This study uses a dynamic factor approach to obtain a measure of global inflation from the national inflation rates of 22 economies. This measure is then found to

31. Openness is also found to be associated with an increase in productivity of $11 \%$, consistent with the hypothesis that the least productive domestic firms are forced to exit from the market as a result of additional import competition.

32. In addition to this direct effect, the study detects a small indirect effect of globalisation on producer prices that works through increased productivity growth.

33. This result is robust to the inclusion of three control variables (import prices, oil prices, and domestic unit labour costs).

34. The rolling regression results use pooled estimates across countries. As noted by Borio and Filardo (2006), the pre-conditions for obtaining unbiased parameters are not fulfilled in the data set used and these results should therefore be interpreted with care. 
be an attractor of national inflation rates suggesting that national inflation rates are indeed sensitive to economic conditions in other countries. This leaves open the issue of what is driving global inflation. ${ }^{35}$

55. A possible corollary to the finding that inflation has become more sensitive to global conditions over time is that it may have become less sensitive to domestic conditions. The latter appears to be a common finding from many empirical studies for individual OECD economies (Melick and Gelati, 2006), although it is not a universal one. For the United States, Dexter et al. (2005) demonstrate that the breakdown in the relationship between domestic capacity utilisation and domestic inflation found in other empirical studies disappears once controls are included for the effects of international trade.

\subsubsection{Changes in exchange-rate pass-through to domestic prices}

56. A number of studies have recently sought to test the proposition by Taylor (2000) that global competition should reduce the extent to which exporting firms are able to pass through exchange rate movements into the domestic currency prices charged to importers. This has been found to have considerable empirical support (see, for example, Olivei, 2002, Gagnon and Ihrig, 2004 and Marazzi et al., 2005). The latter study estimates that exchange rate pass-through to United States import prices has declined from above one-half during the 1980s to around one-fifth during the last decade. This decline is found to be due to both a shift of imports away from commodities to manufacturing goods which tend to have lower pass-through rates (Campa and Goldberg, 2003; Pain et al., 2005) and to a general decline in the exchange rate pass-through across all product categories (Olivei, 2002). Gust et al. (2006) demonstrate in a dynamic general equilibrium model that this observed decline in the exchange rate pass-through stems mainly from the increasing trade integration of the United States. For Japan, a decline in exchange rate pass-through is found to be spread across products, rather than being due to a shift in the composition of imports (Otani et al., 2003). For the euro area, Campa et al. (2005) find that a structural break in the exchange rate pass-through into import prices is evident only in a small number of manufacturing industries. Overall, these results provide indirect evidence that the competitive impact of enhanced openness may matter and that it might vary across economies.

\subsubsection{Changes in inflation persistence}

57. An important issue for monetary policy is whether past inflation has a significant role in determining present inflation (i.e. whether inflation is persistent) or whether expectations of future inflation are more important. ${ }^{36} \mathrm{~A}$ higher degree of inflation persistence implies that stabilising inflation following economic "shocks" may require higher temporary costs to output. This has led to a series of studies testing whether the persistence of domestic inflation has changed over time. Again, the findings differ by country, by period considered and by the estimation technique used (Melick and Galati, 2006). ${ }^{37}$

35. There are some preliminary results in the paper which suggest that the constructed measure of global inflation is significantly correlated with measures of global real and monetary conditions.

36. It is possible that future expectations are based, at least in part, on past inflation.

37. For example, Rudd and Whelan (2005) and O'Reilly and Whelan (2005) find little evidence that inflation persistence in the United States and in the euro area has changed over time, whereas Cogley and Sargent (2001), Clark (2003) and Levin and Piger (2004) all suggest find that inflation persistence is markedly lower in recent years. Debelle and Wilkinson (2002) find that inflation persistence has declined in Australia and New Zealand, but has risen in the United Kingdom and the United States. Cecchetti and Debelle (2006) report only weak evidence of a decline inflation persistence in recent years, even after allowing for a break in the mean of inflation. 
58. IMF (2006c) seek to link the decline in inflation persistence to changes in monetary credibility. The study indeed finds that the fall in inflation persistence over the past two decades was caused by improvements in the credibility of monetary policy. According to these estimates, strengthened monetary credibility reduced inflation persistence (as measured by the coefficient on lagged inflation) from 0.7 in the early 1980 to 0.6 in 2004 .

\subsection{Testing for the impact of globalisation}

59. The empirical analysis in the present study differs from the above studies in several respects. ${ }^{38}$ First, the above studies examine the relationship between globalisation and inflation within an extended Philips-curve framework. Such a framework does not allow for a potential effect of measures of globalisation on price levels. The present study attempts to overcome this by estimating an error correction model for consumer prices, relating prices to import prices, unit labour costs and the domestic output gap. ${ }^{39}$ It thus accounts explicitly for a possible price level effect from globalisation, as reflected in the level of import prices. Secondly, the present study takes a broader view than many others by examining a range of possible effects from globalisation for a large set of OECD countries. Finally, the econometric analysis is complemented by a scenario analysis which quantifies some of the possible impacts of globalisation on domestic inflation, with import price inflation split into commodity and non-commodity components. This provides a richer analysis of underlying inflation dynamics than previous studies.

60. The empirical work examines the impact of globalisation as reflected in the price of imported goods and services. This is done using an error-correction model for the private consumption deflator in 21 OECD economies over the period 1980-2005, with consumer prices being related to import prices, unit labour costs and the domestic output gap: ${ }^{40}$

$$
\begin{aligned}
\Delta \ln P_{i, t}= & \left(\alpha_{0 i}+\varphi_{0 i} D\right)+\left(\alpha_{1 i}+\varphi_{1 i} D\right)\left(\ln P_{i, t-1}-\left(\alpha_{2 i}+\varphi_{2 i} D\right) M_{i, t-1}^{S H} \ln P_{i, t-1}^{M}-\left(1-\left(\alpha_{2 i}+\varphi_{2 i} D\right) M_{i, t-1}^{S H}\right) \ln C_{i, t-1}\right) \\
& +\sum_{j=1}^{4}\left(\beta_{j i}+\phi_{j i} D\right) \Delta \ln P_{i, t-j}+\sum_{j=0}^{4}\left(\gamma_{j i}+\lambda_{j i} D\right) \Delta \ln P_{i, t-J}^{M}+\sum_{j=0}^{4}\left(\delta_{j i}+\kappa_{j i} D\right) \Delta \ln C_{i, t-j} \\
& +\left(\alpha_{3 i}+\varphi_{3 i} D\right) G A P_{i, t-1}+\varepsilon_{i t} .
\end{aligned}
$$

The subscript $i$ denotes the country and the subscript $t$ the time period. The variables are defined as follows: $P$ represents domestic prices measured by the private consumption expenditure deflator, $P^{M}$ represents import prices measured by the deflator of imports of goods and services, $C$ represents domestic costs, proxied by unit labour costs of the total economy, GAP is the domestic output gap, and $\varepsilon$ is an error term. The equations also include seasonal dummies as well as time dummies to account for changes in

38. Technical aspects of the empirical analysis described in this section are reported in more detail in Appendix 1 of this paper.

39. In this respect, the present study is very similar to that of Ihrig and Marquez (2004), who use an error correction model to examine the contribution of productivity advancements and labour market slack to low inflation in OECD countries. However, in contrast to the present study, Ihrig and Marquez (2004) look entirely on domestic factors as drivers of the decline in inflation and do not address the extent to which globalisation lies behind the decline.

40. By estimating an error correction model the possibility of a price level effect from globalisation, as reflected in the level of import prices, is allowed for explicitly. In contrast, most other studies have focused only on the relationship between inflation and globalisation (see, for example, IMF (2006a) and Borio and Filardo (2006). 
indirect taxes and similar events. Static homogeneity is imposed on all equations so that the mark-up of prices over costs is independent of the price level. Dynamic homogeneity is not directly imposed on the system. A test of this restriction is carried out after estimating the system and found to be strongly rejected by the data.

61. Initial parameter stability tests revealed evidence of a significant structural break in the parameters in the consumer price equations in the mid-1990s. To overcome this, two modifications were found to be necessary. The first was to interact the long-run import price coefficient with the share of imports in domestic demand, denoted $M^{S H}$ in [1]. ${ }^{41}$ This implies that the long-run coefficient on import prices rises over time in most countries in the sample, in line with increases in import penetration (see Table 1), with an equivalent decline in the long-run coefficient on domestic unit labour costs. But even with this modification, there continued to be evidence of parameter instability in the mid-1990s. The second modification was thus to allow for separate parameter estimates before and after 1995 by introducing a dummy variable $D$ that is equal to unity from 1995 onwards. This overcomes the parameter instability when there is only a single set of parameters for the whole estimation period. ${ }^{42}$

62. The set of equations is estimated jointly, with cross-country restrictions being imposed as the data permit. ${ }^{43}$ Further details about the estimation procedure are given in Appendix 1. In the empirical model the long-run coefficient on the import price term will reflect not only the direct weight of imports in private consumption, but also the wider influence of import competition on the prices set by actual and potential competitors. The unit labour costs term will reflect indirect effects from globalisation via wages and productivity. An overview of the key empirical findings is provided below, with a more detailed discussion in Appendix 1.

\subsection{Summary of empirical results}

63. The empirical analysis highlights a number of important ways in which the behaviour of consumer prices appears to have changed over the past decade. Of these, the most notable is the extent to which import prices have become a more important determinant of consumer prices over time in all OECD countries, implying that foreign economic conditions have become a more important influence on domestic inflation. At the same time, domestic inflation is found to have become less sensitive to temporary changes in the domestic output gap. Other notable changes include evidence that inflation persistence has declined in most OECD countries and that the speed of adjustment towards the "desired" price level has slowed over the past decade.

41. The import content of consumption is calculated as $M_{i, t}^{S H}=\left(M_{i, t}-\eta_{i} X_{i, t}\right) /\left(M_{i, t}+Y_{i, t}-X_{i, t}\right)$, where $M$ denotes total imports, $X$ denotes total exports, $Y$ denotes domestic output and $\eta$ is the share of imports used in the production of export goods. Estimates of $\eta_{i}$ are taken from Pain et al. (2005, Table 7).

42. This was done by interacting the coefficients with dummy variables that are equal to unity from 1995 onwards. For simplicity, only the results of the final specification are summarised in the main part of the paper. A discussion of the results of the intermediate specifications can be found in Appendix 1.

43. Imposing a single set of parameters common to all countries, as in other studies (IMF 2006a, Borio and Filardo, 2006), was strongly rejected by the data. 
ECO/WKP(2006)52

Table 1. Average import content of domestic demand

Per cent of total expenditure

\begin{tabular}{l|ccc}
\hline \hline & $1980-2005$ & $1980-1994$ & $1995-2005$ \\
\hline Japan & 0.09 & 0.09 & 0.09 \\
United States & 0.11 & 0.09 & 0.12 \\
Canada & 0.15 & 0.13 & 0.17 \\
Germany & 0.15 & 0.14 & 0.16 \\
Switzerland & 0.15 & 0.15 & 0.15 \\
Italy & 0.15 & 0.14 & 0.17 \\
Australia & 0.16 & 0.15 & 0.18 \\
Spain & 0.16 & 0.13 & 0.20 \\
France & 0.17 & 0.16 & 0.17 \\
United Kingdom & 0.17 & 0.16 & 0.19 \\
Finland & 0.18 & 0.17 & 0.18 \\
Greece & 0.18 & 0.17 & 0.19 \\
Austria & 0.19 & 0.17 & 0.20 \\
Sweden & 0.20 & 0.19 & 0.22 \\
Denmark & 0.20 & 0.20 & 0.22 \\
Ireland & 0.21 & 0.20 & 0.22 \\
Portugal & 0.23 & 0.23 & 0.24 \\
Korea & 0.25 & 0.24 & 0.26 \\
Belgium & 0.25 & 0.24 & 0.26 \\
Norway & 0.27 & 0.28 & 0.25 \\
Netherlands & 0.28 & 0.27 & 0.30 \\
\hline \hline
\end{tabular}

Source: OECD Economic Outlook database.

64. During the first part of the sample period, from 1980 to 1994, the data support the formation of two country groups for the interaction term between import prices and import penetration. ${ }^{44}$ The long-run coefficients on the two interaction terms are very different, having values of 2.1 and 0.4 respectively. ${ }^{45}$ In the second part of the sample period, from 1995-2005, the long-run coefficient on the interaction term is found to rise to a common value of 2.6 for both groups of countries. This suggests that during the more recent period domestic producers have increasingly taken greater account of foreign competitors when setting their prices, so that import prices have a larger influence on domestic prices than their share in domestic demand would suggest. The results also imply that the sensitivity of consumer prices to import prices will differ considerably across countries, reflecting differences in import penetration. ${ }^{46}$

44. Full details on the country composition of each group can be found in Table A1.1 of Appendix 1.

45. A coefficient of unity would indicate that the weight on import prices was exactly as might be expected given the share of imports in domestic demand.

46. Earlier attempts at imposing a common long-run coefficient on import prices in each country were rejected by the data, confirming that there are significant differences across countries in the influence of import prices. 
65. The domestic output gap is found to have a significant impact on consumer price inflation in all of the countries in the sample, with the size of the initial impact being smaller in the more recent period. On average across countries, a rise in the domestic output gap by 2 percentage points for four consecutive quarters raises inflation in the following two years by 0.1 percentage point per annum less in the second part of the sample (1995-2005) than in the first part (1980-1994). This is similar to, but slightly smaller than, the finding reported in IMF (2006a).

66. The model employed in the analysis automatically incorporates an indirect effect from foreign economic conditions, as mediated through import prices. ${ }^{47}$ Augmenting the model with an additional world output gap variable and testing the joint significance of the coefficients on this term for all countries suggests that the world output gap does not have any significant impact on domestic consumer price inflation over and above the one that works through import prices. This implies that the importance of foreign economic conditions for domestic inflation will vary across countries, reflecting the different forces that influence international trade prices for each country (Pain et al., 2005), as well as differences in import penetration.

67. The empirical results also indicate that the inflation process has become less persistent in the majority of the countries over the past decade, although in a small number of countries (Finland, Greece, Ireland, and Italy) past inflation appears to have become a more important determinant of current inflation. Given that the model employed in the analysis is equivalent to one in which current inflation is related to past inflation and a fixed level of inflation expectations (see Appendix 1 for details), the change in inflation persistence might be related to a change in the relationship between inflation and inflation expectations. ${ }^{48}$

68. The error correction coefficients, though small in magnitude, are all highly significant in both sub-samples. For the majority of the countries, the error correction coefficients become smaller in the second part of the sample period, implying that the speed of adjustment towards the "desired" price level has slowed. A possible explanation is the more direct focus of monetary policy on inflation objectives over the past decade, with the associated possibility of some degree of price level drift (Svensson, 1999).

69. There is no strong evidence that the short-run reaction of domestic producers to import price changes varies with the type of import goods. When augmenting the equation with current and lagged changes of commodity import prices, these additional terms were found to be significant for only a small number of countries, suggesting that, in general, changes in commodity import prices have the same impact on consumer price inflation as do changes in non-commodity import prices.

\section{Quantifying the overall impact of globalisation}

70. On the basis of the preceding results for commodity and non-commodity price influences, a series of scenario analyses were carried out to obtain illustrative estimates of the possible direct impact of globalisation on consumer price inflation over the past ten years. These incorporate the main findings from the scenario analyses for commodity prices discussed in section 4 , and the estimated "mechanical" impact on import prices as a result of the higher shares of trade with lower-cost producers discussed in section 3 within the context of the consumer price relationships described in section 5. Two alternative starting points for these scenarios are considered, the first quarter of 1995 and the first quarter of 2000.

47. Import prices of OECD economies depend on world export prices which, in turn, reflect capacity constraints and other cyclical conditions in the exporting economy (Pain et al., 2005).

48. For this reason, the finding that the sum of the coefficients on the lagged inflation terms is below unity need not imply a long-run trade-off exists between the level of inflation and the output gap. Inflation expectations, as reflected in the constants, in the estimated equations, also need to be taken into account. 
71. A baseline scenario was obtained by forecasting consumer price inflation employing the coefficient estimates obtained for the period 1995-2005 and actual values of all exogenous variables. The forecast is dynamic in the sense that projected values of consumer prices are employed for the right-handside variables rather than the actual values of the lagged dependent variables. The average annual consumer price inflation rates in the baseline scenario are generally very close to actual annual inflation rates (see Table 2).

Table 2. Average annual consumer price inflation, scenario analysis 1995Q1-2005Q4

\begin{tabular}{|c|c|c|c|c|}
\hline & \multicolumn{2}{|c|}{$\begin{array}{l}\text { Average annual } \\
\text { inflation (in per cent) }\end{array}$} & \multicolumn{2}{|c|}{$\begin{array}{l}\text { Scenario, difference from baseline } \\
\text { (in percentage points) }\end{array}$} \\
\hline & Actual & Baseline & $1 \%$ point & $2 \%$ points \\
\hline Australia & 2.0 & 2.0 & 0.2 & 0.4 \\
\hline Austria & 1.5 & 1.5 & 0.3 & 0.5 \\
\hline Belgium & 1.8 & 1.8 & 0.3 & 0.6 \\
\hline Canada & 1.6 & 1.6 & 0.1 & 0.3 \\
\hline Denmark & 1.9 & 1.8 & 0.3 & 0.6 \\
\hline Finland & 1.7 & 1.7 & 0.2 & 0.3 \\
\hline France & 1.2 & 1.2 & 0.2 & 0.4 \\
\hline Germany & 1.1 & 1.1 & 0.2 & 0.4 \\
\hline Greece & 4.8 & 4.7 & 0.3 & 0.6 \\
\hline Ireland & 2.8 & 2.8 & 0.5 & 0.9 \\
\hline Italy & 3.0 & 3.0 & 0.2 & 0.5 \\
\hline Japan & -0.5 & -0.5 & 0.1 & 0.2 \\
\hline Korea & 4.6 & 4.6 & 0.2 & 0.4 \\
\hline Netherlands & 2.2 & 2.2 & 0.3 & 0.6 \\
\hline Norway & 2.0 & 2.1 & 0.2 & 0.4 \\
\hline Portugal & 2.9 & 2.9 & 0.3 & 0.5 \\
\hline Spain & 3.2 & 3.1 & 0.2 & 0.4 \\
\hline Sweden & 1.5 & 1.6 & 0.3 & 0.6 \\
\hline Switzerland & 0.8 & 0.8 & 0.2 & 0.4 \\
\hline United Kingdom & 2.2 & 2.2 & 0.2 & 0.4 \\
\hline United States & 2.0 & 2.0 & 0.2 & 0.4 \\
\hline Euro Area & 2.0 & 2.0 & 0.2 & 0.5 \\
\hline OECD & 1.7 & 1.7 & 0.2 & 0.4 \\
\hline
\end{tabular}

Note: The scenario assumes that import price inflation (total goods and services) was 1 and 2 percentage points per annum above baseline, respectively; all scenarios use the consumer price inflation model reported in Annex 2.

72. Then, various scenarios are undertaken by modifying the series on import price inflation, with import price inflation separated into its commodity and non-commodity parts. This requires assumptions about the rate of commodity and non-commodity import price inflation if had globalisation not taken place. To take account of the uncertainty that surrounds the impact of globalisation on import prices, the scenario analysis derives a range of estimates employing different assumptions on the change in commodity and non-commodity import price inflation.

73. Regarding the growth rate of commodity import prices, the scenario analysis draws on the results in section 4 of the paper, which derive an alternative path for each commodity price under the assumption of slower rates of growth in non-OECD trade and GDP since 2000. These changes are then combined 
using information on the composition of commodity imports to generate an alternative profile for the price of imported commodities in each OECD economy in the sample. ${ }^{49}$ Two alternative profiles are constructed, one for each of the separate oil price estimates discussed in section 4.

74. For the growth rate of non-commodity import prices, the scenario analysis assumes that in the absence of the rising level of imports from low-cost producers, price inflation would have exceeded the actual growth rate by 1 or 2 percentage points per annum, respectively. This reflects the range of estimates discussed in section 3 .

75. Tables 2 and 3 compare the different scenarios by reporting differences from the baseline in average annual rate of inflation. For the simulation period from 1995 to 2005 , only the results of the modification of non-commodity import price inflation are reported in Table 2. This provides a longer-term perspective on the influence of globalisation in the absence of any impact on commodity prices. If the prices of non-commodity imports had risen by 1 percentage point ( 2 percentage points) more per annum since 1995, inflation would, on average, have been 0.2 percentage point ( 0.4 percentage point) per annum higher in the OECD economies. ${ }^{50}$ Starting the simulation in 2000 reduces the difference in OECD inflation from the baseline to 0.1 and 0.2 percentage point per annum, respectively. ${ }^{51}$

76. The impact of the changes in commodity import prices over the period 2000-05 is reported in Table 3 and summarised in Figure 18. In the scenario with a 20\% decline in oil prices, OECD inflation is found to be reduced by 0.08 percentage point per annum on average from 2000 onwards. In the scenario with a $40 \%$ decline in oil prices, OECD inflation is reduced by 0.15 percentage point per annum. The impact differs considerably across countries, with the smallest changes found for Norway, Canada and the United Kingdom, and the highest found for Korea. ${ }^{52}$

77. The final column in Table 3 shows the combined effect on consumer inflation from higher noncommodity import price inflation and lower commodity import price inflation (see also Figure 18). The analysis suggests that consumer price inflation could have been up to 0.3 percentage point higher per annum in the euro area had the estimated effect of globalisation not occurred. For the United States, the estimated impact ranges from -0.04 to 0.21 percentage point per annum, suggesting that US inflation might even have been lower in the absence of globalisation. ${ }^{53}$ For Japan, the net effect is very small, ranging from -0.04 to 0.06 percentage point per annum. The uncertainty surrounding the estimates for most countries tends to be quite large as indicated by the difference between the lower and the upper bound which amounts to over 0.2 percentage point on average.

49. The weights of individual commodities in total imports are calculated as described in Pain et al., (2005).

50. Ireland is an exception, with average annual inflation rates some 0.5 and 0.9 percentage point higher than in the baseline. This reflects both the comparatively high level of import penetration in Ireland and the faster speed at which changes in import prices are reflected in domestic prices.

51. The calculations do not account for differences in the regional composition of imports. For example, the disinflationary impact may be underestimated for Japan given the comparatively higher share of imports from China in total Japanese imports.

52. This stems from the comparatively high share of oil in Korea's imports.

53. This requires that globalisation has had a large impact on commodity import prices, but a small impact on non-commodity import prices. 
Figure 18. The impact on consumer price inflation from removing globalisation effects 2000-05

Average percentage point difference per annum

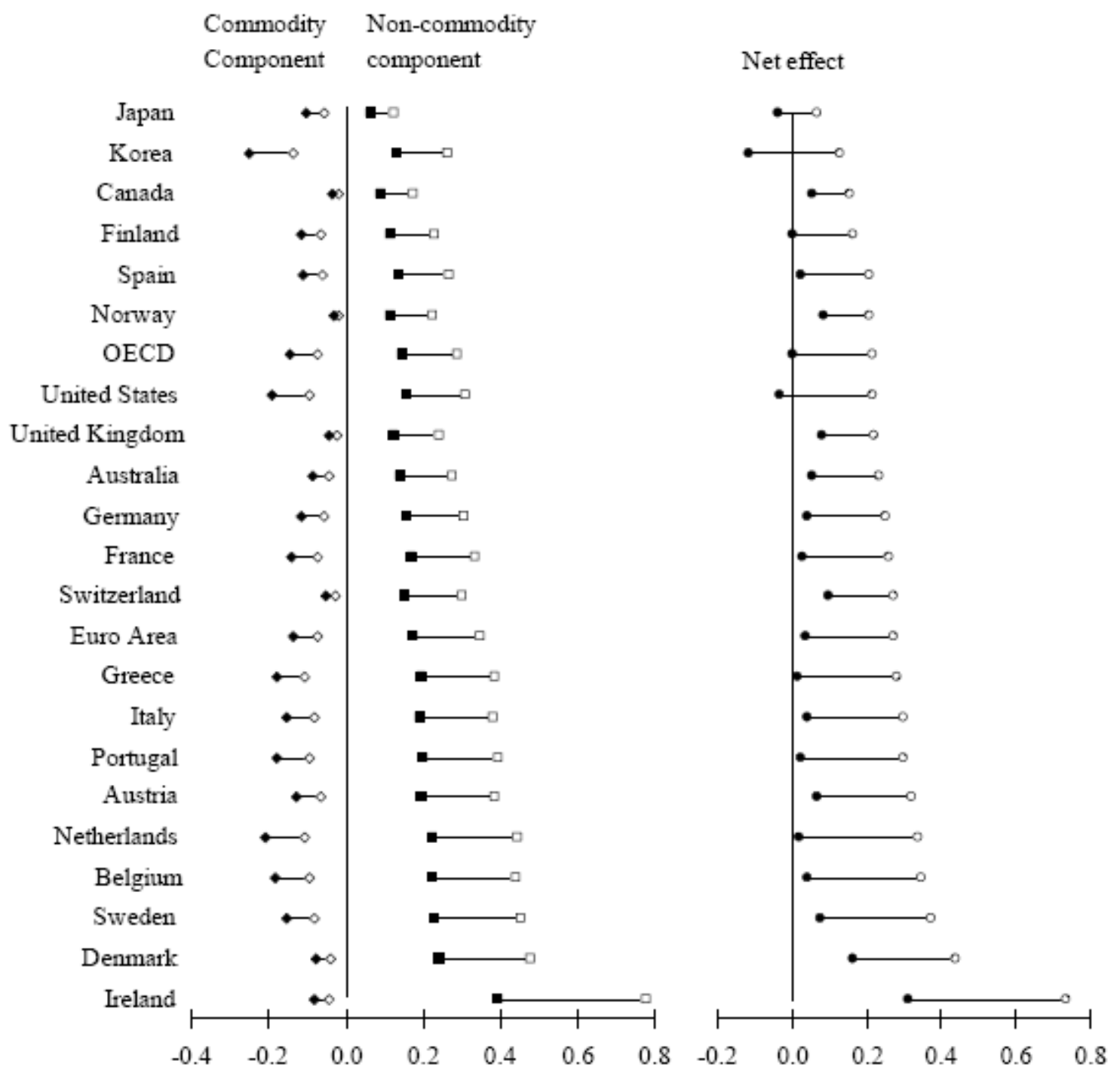

- Lower bound of commodity import price effect ( $20 \%$ oil, $10 \%$ metals)

- Upper bound of commodity import price effect ( $40 \%$ oil, $10 \%$ metals)

- Lower bound of non-commodity import price effect (1\%)

口 Upper bound of non-commodity import price effect (2\%)

- Lower bound of net effect

- Upper bound of net effect

- Range of possible impact

Note: See notes to Table 3. 
Table 3. Average annual consumer price inflation, scenario analysis 2000Q1-2005Q4

\begin{tabular}{|c|c|c|c|c|c|c|}
\hline & \multirow{3}{*}{$\begin{array}{c}\text { Average annual } \\
\text { inflation } \\
\text { (actual, in \%) }\end{array}$} & \multicolumn{5}{|c|}{ Difference from baseline (in percentage points) } \\
\hline & & \multicolumn{2}{|c|}{ Non-commodity component } & \multicolumn{2}{|c|}{ Commodity component } & \multirow[t]{2}{*}{ Net effect } \\
\hline & & $1 \%$ point & $2 \%$ points & $\begin{array}{c}40 \% \text { oil } \\
10 \% \text { metals } \\
\end{array}$ & $\begin{array}{c}20 \% \text { oil } \\
10 \% \text { metals } \\
\end{array}$ & \\
\hline Australia & 2.4 & 0.1 & 0.3 & 0.0 & -0.1 & $0.0-0.2$ \\
\hline Austria & 1.8 & 0.2 & 0.4 & -0.1 & -0.1 & $0.1-0.3$ \\
\hline Belgium & 2.3 & 0.2 & 0.4 & -0.1 & -0.2 & $0.0-0.3$ \\
\hline Canada & 1.8 & 0.1 & 0.2 & 0.0 & 0.0 & $0.0-0.1$ \\
\hline Denmark & 2.1 & 0.2 & 0.5 & 0.0 & -0.1 & $0.2-0.4$ \\
\hline Finland & 1.9 & 0.1 & 0.2 & -0.1 & -0.1 & $0.0-0.2$ \\
\hline France & 1.5 & 0.2 & 0.3 & -0.1 & -0.1 & $0.0-0.3$ \\
\hline Germany & 1.4 & 0.2 & 0.3 & -0.1 & -0.1 & $0.0-0.2$ \\
\hline Greece & 3.4 & 0.2 & 0.4 & -0.1 & -0.2 & $0.0-0.3$ \\
\hline Ireland & 2.5 & 0.4 & 0.8 & 0.0 & -0.1 & $0.3-0.7$ \\
\hline Italy & 2.8 & 0.2 & 0.4 & -0.1 & -0.2 & $0.0-0.3$ \\
\hline Japan & -1.0 & 0.1 & 0.1 & -0.1 & -0.1 & $0.0-0.1$ \\
\hline Korea & 3.6 & 0.1 & 0.3 & -0.1 & -0.3 & $-0.1-0.1$ \\
\hline Netherlands & 2.7 & 0.2 & 0.4 & -0.1 & -0.2 & $0.0-0.3$ \\
\hline Norway & 1.9 & 0.1 & 0.2 & 0.0 & 0.0 & $0.1-0.2$ \\
\hline Portugal & 3.0 & 0.2 & 0.4 & -0.1 & -0.2 & $0.0-0.3$ \\
\hline Spain & 3.3 & 0.1 & 0.3 & -0.1 & -0.1 & $0.0-0.2$ \\
\hline Sweden & 1.5 & 0.2 & 0.5 & -0.1 & -0.2 & $0.1-0.4$ \\
\hline Switzerland & 1.0 & 0.1 & 0.3 & 0.0 & -0.1 & $0.1-0.3$ \\
\hline United Kingdom & 1.7 & 0.1 & 0.2 & 0.0 & -0.1 & $0.1-0.2$ \\
\hline United States & 2.2 & 0.2 & 0.3 & -0.1 & -0.2 & $0.0-0.2$ \\
\hline Euro Area & 2.1 & 0.2 & 0.3 & -0.1 & -0.1 & $0.0-0.3$ \\
\hline OECD & 1.8 & 0.1 & 0.3 & -0.1 & -0.1 & $0.0-0.2$ \\
\hline
\end{tabular}

Note: The lower (upper) bound of the total impact is calculated assuming that the prices of non-commodity import price inflation was 1 percentage point (2 percentage points) per annum above baseline and that commodity import prices reflect the $20 \%(40 \%)$ oil price estimate. In both cases the metals price effect is $10 \%$. 
ECO/WKP(2006)52

\section{REFERENCES}

Adams, F.G. and Y. Ichino (1995), "Commodity prices and inflation: A forward-looking price model", Journal of Policy Modeling, Vol. 17, pp.397-426.

Banerjee, A. and B. Russell (2001), "The relationship between the mark-up and inflation in the G7 economies and Australia", Review of Economics and Statistics, Vol. 83, pp.377-387.

Banerjee, A., P. Mizen and B. Russell (2002), "The long-run relationship among relative price variability, inflation and the mark-up", European University Institute Working Paper No.2002/1.

Banerjee, A. and B. Russell (2005), "Inflation and measures of the mark-up", Journal of Macroeconomics, Vol. 27, pp.289-306.

Bean, C. (2006), "Comments on "The impact of globalisation on monetary policy", presented at the Federal Reserve Bank of Kansas City $30^{\text {th }}$ Annual Economic Symposium, Jackson Hole, Wyoming.

Borio, C. and A. Filardo (2006), "Globalisation and inflation: New cross-country evidence on the global determinants of domestic inflation", mimeo, Bank for International Settlements.

Brook, A-M., R. Price, D. Sutherland, N. Westerlund and C. André, (2004), "Oil price developments: drivers, economic consequences and policy responses", OECD Economics Department Working Paper No.412.

Campa, J.M., L.S. Goldberg and J.M Gonzáles-Mínguez (2005), "Exchange rate pass-through to import prices in the euro area", Federal Reserve Bank of New York Staff Report No.219.

Campa, J.M. and L.S. Goldberg (2003), "Exchange rate pass-through into import prices: A macro or micro phenomenon?", NBER Working Paper No. 8934.

CBO (2006), China's growing demand for oil and its impact on U.S. petroleum markets, Congressional Budget Office Paper, Congress of the United States.

Cecchetti S.G. and G. Debelle (2006), "Has the inflation process changed?", Economic Policy, Vol. 21, pp.311-352.

Chen, N., J. Imbs and A. Scott (2004), "Competition, globalization and the decline of inflation", Centre for Economic Policy Research Discussion Paper No.4695.

Ciccarelli, M. and B. Mojon (2005), "Global inflation”, Banco Central de Chile Working Paper No.357.

Clark, T. (2003), "Disaggregated evidence on the persistence of consumer price inflation", Federal Reserve Bank of Kansas City Working Paper No.03-11.

Cogley T. and T. Sargent (2001), "Evolving post-World War II inflation dynamics", NBER Macroeconomics Annual, Vol. 16, pp.331-373. 
Corrado, C. and J. Mattey (1997), "Capacity utilization", Journal of Economic Perspectives, Vol. 11, pp.151-67.

Dai-ichi Life (2004), "Chugokuna Infure/Kokusai Shohin Shikyo Koto ha Nihon no Defure wo Kaishosaseruka" (Can Chinese inflation and the international commodity market boon solve the deflation problem in Japan?).

Debelle, G. and J. Wilkinson (2002), "Inflation targeting and the inflation process: some lessons from an open economy", Reserve Bank of Australia Research Discussion Paper No.2002-01.

Dexter, A.S., M.D. Levi and B.R. Nault (2005), "International trade and the connection between excess demand and inflation", Review of International Economics, Vol. 13, pp.699-708.

Dumont, M., G. Rayp and P. Willeme (2006), "Does internationalisation affect union bargaining power? An empirical study for five EU countries", Oxford Economic Papers, Vol.58, pp.77-102.

ECB (2006), "Effects of the rising trade integration of low-cost countries on euro area import prices", European Central Bank Monthly Bulletin, August 2006, pp.56-57.

Feyzioğlu, T. and L. Willard (2006), "Does inflation in China affect the United States and Japan?”, IMF Working Paper No.06/36.

Frankel, J. (2006), "The effect of monetary policy on real commodity prices", revised version of paper presented at NBER Conference on Asset Prices and Monetary Policy, Chatham, Massachusetts.

Gagnon, J. and J. Ihrig (2004) "Monetary policy and exchange rate pass-through," International Journal of Finance and Economics, Vol. 9, pp.315-338.

Gamber, E.N. and J.H. Hung (2001), "Has the rise in globalisation reduced U.S. inflation in the 1990s?", Economic Inquiry, Vol.39, pp.58-73.

Ghosal, V. (2000), "Product market competition and the industry price-cost markup fluctuations: the role of energy price and monetary changes, International Journal of Industrial Organization, Vol. 18, pp.415-444.

Gust, C.J., S. Leduc and R.J. Vigfusson (2006), "Trade integration, competition, and the decline in exchange-rate pass-through", Board of Governors of the Federal Reserve System, International Financial Discussion Paper No.864.

Hansen, B.E. (1992), "Testing for parameter instability in linear models", Journal of Policy Modeling, Vol. 14, pp.517-533.

Haskel, J., C. Martin and I. Small (1995), "Price, marginal cost and the business cycle", Oxford Bulletin of Economics and Statistics, Vol. 57, pp.25-41.

Hodgetts, B. (2006), "Changes in the inflation process in New Zealand", Reserve Bank of New Zealand Bulletin, Vol. 69/1, pp.18-30.

Holtham, G. and M. Durand (1987), 'OECD economic activity and non-oil commodity prices: reducedform equations for Interlink”, OECD Economics Department Working Paper No.42. 
Hua, P. (1998), "On primary commodity prices: the impact of macroeconomic/monetary shocks", Journal of Policy Modeling, Vol. 20, pp.767-790.

IEA (2006), Oil Market Report -Annual Statistical Supplement for 2005 and User's Guide, International Energy Agency, Paris.

Ihrig, J. and J. Marquez (2004), “An empirical analysis of inflation in OECD countries", International Finance, Vol. 7, pp.61-84.

IMF (2006a), "How has globalisation affected inflation?", IMF World Economic Outlook, April, Chapter 3.

IMF (2006b), "The boom in non-fuel commodity prices: Can it last?", IMF World Economic Outlook, September, Chapter 5.

Kamin, S., M. Marazzi and J.W. Schindler (2006), "The impact of Chinese exports on global import prices", Review of International Economics, Vol. 14, pp.179-201.

Kaplinsky, R. (2005), "China, globalisation and neo-liberal dogma", paper prepared for 50th Anniversary Conference, Queen Elizabeth House, Oxford, 4-6 July.

Kohn, D.L. (2006), "The effects of globalisation on inflation and their implications for monetary policy", presented at the Federal Reserve Bank of Boston's 51 ${ }^{\text {st }}$ Economic Conference, Chatham, Massachusetts.

Levin, A. and J. Piger (2004): "Is inflation persistence intrinsic in industrial economies?", ECB Working Paper No.343.

Marazzi, M., N. Sheets and R. Vigfusson (2005), "Exchange rate pass-through to US import prices: some new evidence", Board of Governors of the Federal Reserve System, International Financial Discussion Paper No.833.

Markandya, A., S. Pedroso-Galinato and D. Streimikiene (2006), "Energy intensity in transition economies: Is there convergence towards the EU average?", Energy Economics, Vol. 28, pp.121145.

Melick, W. and G. Gelati (2006), "The evolving inflation process: an overview", Bank for International Settlements Working Paper No.196.

Nickell, S. (2005), "Why has inflation been so low since 1999?", Bank of England Quarterly Bulletin, Spring 2005, pp.92-107.

OECD (2005), Economic Survey of China, OECD, Paris.

OECD (2006), OECD Economic Outlook, Vol. 2006/1, OECD, Paris.

Olivei, G. P. (2002), "Exchange rates and the prices of manufacturing products imported into the United States", New England Economic Review, First quarter, pp.3-18.

O'Reilly, G. and K. Whelan (2005), "Has euro-area inflation persistence changed over time?", Review of Economics and Statistics, Vol. 87, pp.709-720. 
Otani, A., S. Shiratsuka and S. Toyoichiro (2003), The decline in the exchange rate pass-through: evidence from Japanese import prices, Bank of Japan, Institute for Monetary and Economic Studies.

Pain, N., A. Mourougane, F. Sédillot and L. Le Fouler (2005), “The new international trade model”, OECD Economics Department Working Paper No.440.

Pain, N., M. Molnar and D. Taglioni (2006), "The internationalisation of production, international outsourcing and OECD labour markets", OECD Economics Department Working Paper (forthcoming).

Rae, D. and D. Turner (2001), "A small global forecasting model", OECD Economics Department Working Papers No.286.

Rodrik, D. (1999) "Globalization and labor, or: If globalization is a bowl of cherries, why are there so many glum faces around the table?" in R.E. Baldwin et al., eds., Market Integration, Regionalism and the Global Economy, Cambridge University Press, for CEPR New York.

Rogoff, K. (2006), "The impact of globalisation on monetary policy", presented at the Federal Reserve Bank of Kansas City $30^{\text {th }}$ Annual Economic Symposium, Jackson Hole, Wyoming.

Rudd, J. and K. Whelan (2005), "Modelling inflation dynamics: a critical review of recent research," Board of Governors of the Federal Reserve System, Finance and Economics Discussion Series No.2005-66.

Stock, J.H. and M.W. Watson (2005), "Has inflation become harder to forecast?", Princeton University, Department of Economics, unpublished manuscript.

Stone, A., T. Wheatley and L. Wilkinson (2005), "A small model of the Australian macroeconomy: An update", Reserve Bank of Australia Research Discussion Paper No.2005-11.

Svensson, L.O. (1999), "Price level targeting vs. inflation targeting: a free lunch?", Journal of Money, Credit and Banking, Vol. 31, pp.277-295.

Taylor, J. (2000), "Low inflation, pass-through, and the pricing power of firms", European Economic Review, Vol. 44, pp.1389-1408.

Temple, J. (2002), "Openness and inflation: a new assessment", Quarterly Journal of Economics, Vol. CXIII, pp.641-648.

Tootell, G.M. B. (1998), "Globalisation and U.S. inflation", Federal Reserve Bank of Boston, New England Economic Review (July/August), pp.21-33.

Vega, M. and D. Winkelried (2004), "How does global disinflation drag inflation in small open economies?", Central Bank of Peru Working Paper No.2005-01.

Wu, C.-S. and J.-L. Lin (2006), "The relationship between openness and inflation in Asian 4 and G7", presented at the NBER $17^{\text {th }}$ Annual East Asian Seminar on Economics, Kohala Coast, Hawaii.

Zellner, A. (1962), "An efficient method of estimating seemingly unrelated regressions and tests for aggregation bias ", Journal of the American Statistical Association, Vol. 57, pp.348-368. 
ECO/WKP(2006)52

\section{APPENDIX 1: GLOBALISATION AND CONSUMER PRICE INFLATION}

\section{A1.1 Introduction and summary}

78. This appendix provides further technical details on the empirical work stimulation discussed in section 5 of the main paper, including the detailed estimation results. These estimates suggest that the inflation process in OECD countries changed around the mid-1990s, around the time at which the extent of globalisation began to rise markedly. Accounting for this structural change leads to several important findings. Of these, the most notable is that the impact of import prices on consumer prices is higher after the break in all countries. In addition, the short to medium-term response of inflation to cyclical output variations is found to have declined over the past decade, implying an increase in the sacrifice ratio. Finally, inflation persistence appears to have declined in most OECD countries. This may be the result of better anchored inflation expectations, but this is not tested directly in estimation.

\section{A1.2 Set-up of the empirical analysis}

79. As outlined in section 5.3, the empirical analysis in the present study differs from those of other studies in several respects. Firstly, it allows for a potential effect of measures of globalisation on price levels by estimating an error correction model for consumer prices, relating prices to import prices, unit labour costs and the domestic output gap. Secondly, it takes a broader view than many other studies by examining a wider range of possible effects from globalisation for a large set of OECD countries.

80. The empirical work uses quarterly data for 21 OECD countries over the period $1980-2005 .{ }^{54}$ All data are taken from the most recent OECD Economic Outlook database if not otherwise specified. The indicator of domestic inflation is the private consumption deflator (PCP). This provides a broader measure of inflation than many national consumer or retail price series, and is in principle more directly comparable across countries because it comes from the system of national accounts.

81. To investigate the potential impact of globalisation on inflation, a system of 21 price equations -- one for each country in the sample -- was estimated. The initial set of equations had the general form:

$$
\begin{aligned}
\Delta \ln P_{i, t}= & \alpha_{0 i}+\alpha_{1 i}\left(\ln P_{i, t-1}-\alpha_{2 i} \ln P_{i, t-1}^{M}-\left(1-\alpha_{2 i}\right) \ln C_{i, t-1}\right) \\
& +\sum_{j=1}^{4} \beta_{j i} \Delta \ln P_{i, t-j}+\sum_{j=0}^{4} \gamma_{j i} \Delta \ln P_{i, t-J}^{M}+\sum_{j=0}^{4} \delta_{j i} \Delta \ln C_{i, t-j}+\alpha_{3 i} G A P_{i, t-1}+\varepsilon_{i t},
\end{aligned}
$$

where the subscript $i$ denotes the country and the subscript $t$ the time period. The variables are defined as follows: $P$ represents domestic prices measured by the private consumption expenditure deflator, $P^{M}$

54. The countries included in the analysis are Australia, Austria, Belgium, Canada, Denmark, Finland, France, Germany, Greece, Ireland, Italy, Japan, Korea, the Netherlands, Norway, Portugal, Spain, Sweden, Switzerland, the United Kingdom, and the United States. 
represents import prices measured by the deflator of imports of goods and services, $C$ represents domestic costs, proxied by unit labour costs of the total economy, GAP is the domestic output gap, and $\varepsilon$ is an error term. ${ }^{55}$ Static homogeneity was imposed on all equations so that the mark-up of prices over costs is independent of the price level. ${ }^{56}$ The long-run import price coefficient $\left[\alpha_{2}\right]$ captures both the direct arithmetic effect on domestic prices of a relative decline in import prices and any indirect effect resulting from downward pressure on the prices of domestic producers as a result of greater competition, but not any indirect effects via wages and productivity. The latter will be reflected in the unit labour cost term. ${ }^{57}$

82. The system of equations is estimated using the seemingly unrelated regression procedure (SUR), first proposed by Zellner (1962). This allows for the possibility of non-zero co-variances across the error terms in the separate country equations and at least in its initial form, allows all coefficients to differ across countries. To obtain a parsimonious model, the parameters are restricted subsequently to be equal across subsets of countries as the data permits. ${ }^{58}$ It should be noted that the groups that are formed are ones that are data acceptable, so they do not necessarily have a direct economic interpretation. Dynamic coefficients that are found to be insignificant at conventional significance levels are set to zero.

83. After successively restricting the parameters in equation [A1.1] to be equal across subsets of countries, an initial restricted system was obtained with four different error correction parameters $\left[\alpha_{0}\right]$ and three different long-run import price coefficients $\left[\alpha_{2}\right] .{ }^{59}$ Though small in magnitude, all obtained error correction coefficients were significantly negative, indicating that a valid long-run equilibrium relationship exists between the private consumption expenditure deflator, the import price deflator and unit labour costs for each country in the sample. The relative weight given to import prices was found to vary markedly across country groups. ${ }^{60}$

55. The equations also include seasonal dummies as well as time dummies to account for changes in indirect taxes and similar events. Note that the model outlined in equation [A1.1] is very similar to the model employed by Ihrig and Marquez (2004). The main difference lies in the inclusion of dynamic unit labour costs and import price terms that are not present in the model of Ihrig and Marquez.

56. Dynamic homogeneity is not directly imposed on the system. A test of this restriction carried out after estimating the system was strongly rejected by the data. This implies that any steady-state shift in the rate of inflation has a permanent effect on the mark-up. For a discussion on the relationship between inflation and the mark-up see, for example, Banerjee and Russell (2001, 2005), Banerjee, Mizen, and Russell (2002), and Stone, Wheatley, and Wilkinson (2005).

57. Note that specification [1] implies that the mark-up over marginal costs behaves procyclically, increasing during an economic upturn and falling during an economic downturn. This proposition is in line with the empirical evidence provided by Haskel et al., (1995) and Ghosal (2000).

58. Moving from this partly restricted set of country equations to an alternative with common (slope) coefficients imposed across all countries is strongly rejected by the data suggesting that the use of conventional panel data estimators, such a fixed effects model, could yield biased and inconsistent parameter estimates. This is also in line with the literature discussion in section 5.2 of the main paper, which highlighted that the relationship between globalisation and inflation appears to differ across countries. While imposing cross-country constraints increases the efficiency of the estimation, the point estimates of the final common coefficients of course deviate from the point estimates of country-specific coefficients. These deviations may be particularly pronounced in cases in which the country-specific coefficients are very imprecisely estimated.

59. A Wald test cannot reject the null hypothesis that the set of restrictions holds. The corresponding $p$-value is 0.062 .

60. The point estimates of the coefficients on import prices are $0.14,0.36$ and 0.59 , respectively. 


\section{A1.3 Accounting for structural breaks}

84. The robustness of the restricted system of equations discussed in the previous section was assessed using rolling regressions of this model and a formal test for a structural break in the coefficients from 1995Q1. As shown in Figures 7 and 8 in the main paper, this coincides with a period in which there has been a marked increase in the extent of globalisation and a marked decline in the mean of consumer price inflation. The structural break test indicates a significant break in the underlying model at this time.

85. With rolling regressions indicating a rise in the long-run import coefficient $\left[\alpha_{2}\right]$ over time for most of the countries in the sample, equation [A1.1] was re-specified by allowing the coefficient on the long-run import price term to be multiplied by a measure of the import content of domestic demand (denoted $M^{\text {SH }}$ below): ${ }^{61}$ The modified equation is:

$$
\begin{aligned}
\Delta \ln P_{i, t}= & \alpha_{0 i}+\alpha_{1 i}\left(\ln P_{i, t-1}-\alpha_{2 i} M_{i, t-1}^{S H} \ln P_{i, t-1}^{M}-\left(1-\alpha_{2 i} M_{i, t-1}^{S H}\right) \ln C_{i, t-1}\right) \\
& +\sum_{j=1}^{4} \beta_{j i} \Delta \ln P_{i, t-j}+\sum_{j=0}^{4} \gamma_{j i} \Delta \ln P_{i, t-J}^{M}+\sum_{j=0}^{4} \delta_{j i} \Delta \ln C_{i, t-j}+\alpha_{3 i} G A P_{i, t-1}+\varepsilon_{i t} .
\end{aligned}
$$

The import content of domestic demand is calculated as $M_{i, t}^{S H}=\left(M_{i, t}-\eta_{i} X_{i, t}\right) /\left(M_{i, t}+Y_{i, t}-X_{i, t}\right)$, where $M$ denotes total imports, $X$ denotes total exports, $Y$ denotes domestic output and $\eta$ is the share of imports used in the production of export goods. Estimates of $\eta_{i}$ are taken from Pain et al (2005, Table 7). As the time series obtained for the import content of consumption display marked quarterly fluctuations, the series is smoothed by taking a three-year moving average. ${ }^{62}$ The resulting series trend upwards for the majority of the countries over the period 1980 to 2005 . $^{63}$

\section{A1.3.1 Evidence from a full-sample regression}

86. The initial set of results from estimating equation [A1.2], again using the SUR procedure, are summarised in the columns headed ' $1980-2005$ ' in Table A1.1. On this basis, it is possible to impose a smaller number of data-based restrictions to give a simplified specification, with separate long run import price coefficients $\left(\alpha_{2 \mathrm{i}}\right.$ in [A1.2]) for two country groups and separate error-correction parameters $\left(\alpha_{1 \mathrm{i}}\right.$ in [A1.2]) for three country groups. Each error-correction parameter is significant and negative but small in magnitude. $^{64}$

87. The two long-run coefficients on import prices are estimated to be 2.3 and 0.6 , respectively. As the elasticity of consumer prices to import prices is given by the product of the coefficient $\alpha_{2}$ and the import content of consumption $\left(M^{S H}\right)$, there are notable differences in this elasticity across countries

61. A similar approach has been adopted in a number of related studies. See, for instance, Gamber and Hung (2001) and IMF (2006a).

62. Employing the three-year moving average instead of the original series does not have any major impact on the estimation results.

63. Note that specification [A1.2] implies that the reaction of the mark-up to changes in the import content of consumption depends on the ratio between import prices and unit labour costs: $\partial \ln \left(P_{i} / C_{i}\right) / \partial M_{i}^{S H}=\alpha_{2 i} \ln \left(P_{i, t}^{M} / C_{i, t}\right)$. If import prices are initially higher (lower) than unit labour costs, the mark-up increases (decreases) with a rise in the import content of consumption.

64. Ihrig and Marquez (2004), who estimate a similar model on a country-by-country basis, obtain errorcorrection parameters that are in many cases not significantly different from zero or even positive. 
belonging to the same group. For example, Japan and Korea are both in the group with the lower import price coefficient, but the sample average elasticity is three times higher for Korea than for Japan due to a higher import content of domestic demand. Likewise, countries with different long-run import price coefficients can still have similar elasticities. The implied elasticity for the Netherlands, which is in the group with the lower import price coefficient, is comparable in size to the elasticity of some countries in the high-coefficient group because the Netherlands has a comparatively high import content of domestic demand (see Table 1 in the main text).

88. Movements in the domestic output gap are found to have a small, but statistically significant impact on consumer price inflation in all countries apart from Germany, where the short-run coefficient on the output gap is not significant at conventional significance levels. ${ }^{65}$ The size of the impact varies widely across countries, with the smallest impact found for Spain, Portugal, Sweden, and the United Kingdom, where a 1 percentage point rise in the output gap increases consumer price inflation by $0.01 \%$ in the first quarter of the change. The highest impact is found for Ireland, where the same shock raises inflation by 0.06 per cent in the first quarter.

89. Despite allowing the long-run coefficient on import prices to vary over time in line with import penetration, the modified specification was still found to have a structural break in the first quarter of 1995. ${ }^{66}$ Given that the inclusion of the import penetration term could be expected to control, at least in part, for additional globalisation related effects, it is possible that the continuing evidence of a structural break reflects the changes in the mean and the variability of inflation that occurred around the mid-1990s (see Figures 1 and 2 in the main text). This supposition is supported by the findings from a second structural break test, using the approach of Hansen (1992). This second test finds evidence of a possible break in the volatility of inflation for most countries in the sample (at some unknown point in the sample). ${ }^{67}$

\section{A1.3.2 Evidence from a model with split-sample coefficients}

90. To account for the continued finding of a structural break the model is re-specified, with all parameters being interacted with a dummy variable (denoted $\mathrm{D}$ below) equal to unity from the first quarter of 1995 onwards. The re-specified general model is shown as equation [1] in the main paper. This regression is also run over the full sample period from 1980 to 2005. In estimating the model, coefficients are grouped across countries on the basis of the results obtained from the previous restricted system with the single set of coefficients over the full sample period. Initially, all parameters are interacted with the dummy variable. Insignificant coefficients on the interaction terms are subsequently dropped from the model, so that only those parameters that exhibit a significant break in the first quarter of 1995 are ultimately interacted with the dummy variable. The remaining coefficients are applicable over the whole sample period.

65. This result differs from Ihrig and Marquez (2004) who find a significant impact of measures of domestic economic slack on inflation for less than half of the countries in their sample.

66. A dummy variable test is used, with each variable in the restricted system of equations being interacted with a dummy equal to unity from 1995Q1 and zero before. The parameters on the dummied terms are found to be jointly significant when included in the restricted system, indicating the presence of a structural break in at least one of coefficients in the original restricted model.

67. Note that this test was carried out on a slightly different specification. 
91. The results of the regression are summarised in Tables A1.1, A1.2 and A1.3. ${ }^{68}$ Four aspects of the different parameters pre- and post-1995 stand out -- the increased importance of import prices, a reduction in the size of the error-correction coefficients, a reduction in inflation persistence and a reduced short-run sensitivity of inflation to movements in the domestic output gap.

92. During the first part of the sample period, from 1980 to 1994, the two separate grouped coefficients on the interaction term between import prices and import penetration are very different with values of 2.07 and 0.38 , respectively. Both grouped coefficients are found to be larger in the later period from 1995-2005, although this time the imposition of a common coefficient (of 2.61) cannot be rejected. The increase in the coefficient is especially marked for some European economies and also Japan. The rise in the coefficient suggests that in recent years domestic producers have begun to take greater account of foreign competitors when setting their prices. ${ }^{69}$ Of course, the resulting long-run elasticity on import prices will still differ across countries, reflecting differences in import penetration (see Table A1.4) ${ }^{70}$ The lowest elasticities are found for the United States and Japan which, given their size, is not surprising (the elasticities for these to countries amount to 0.31 and 0.22 on average over the period 1995 to 2005). ${ }^{71}$ The highest import price elasticities are generally found for small open economies such as Belgium, The Netherlands, Norway, Portugal, and Korea, which show elasticities well above 0.5.

93. The domestic output gap is found to have a significant influence on consumer price inflation in all countries, with the impact on inflation of a change in the gap being smaller in the more recent period. This decline in the short-run reaction of inflation to changes in domestic economic conditions is in line with the findings of other recent studies on this issue (IMF 2006a; Stock and Watson, 2005; Melick and Gelati 2006; Borio and Filardo, 2006). On average across all the countries in the sample, a rise in the output gap of 2 percentage points for four consecutive quarters is estimated to raise inflation in the following two years by 0.1 percentage point per annum less in the most recent period compared to the earlier period. Other recent studies suggest that the decline in the short-run reaction of inflation to output gap changes could be even larger (see, for example, the studies by IMF, 2006a and Borio and Filardo, 2006).

94. The grouped error correction coefficients are statistically significant in both halves of the estimation period, though their magnitude remains small. In the second half of the sample two of the

68. Note that static homogeneity is imposed on all equations, whereas dynamic homogeneity is not. The data strongly reject dynamic homogeneity for all countries except Greece, for which dynamic homogeneity is at least supported for the second half of the sample period (the respective $p$-value is 0.34 ).

69. This interpretation rests on the assumption that import prices are weakly exogenous to the system. Testing for weak exogeneity of import prices is not feasible in the current setting as it would require including a full set of import price equations in the system being estimated. If import prices were not exogenous, the rise in the coefficient could also reflect an increase in pricing to market by importers. However, it is possible to establish that the current change term in import prices is exogenous to the system, as shown by a Wu-Hausman test (the respective $p$-value is 0.11 ). The tests entails regressing the current change in import prices on a set of explanatory variables that are clearly exogenous to the system and then testing whether the residuals from this regression have any explanatory power in addition to the variables already included in the system

70. No constraints have been imposed on the long-run import price coefficients that would guarantee that the resulting import price elasticities are smaller than unity and, hence, that the long-run elasticities on unit labour costs are nonnegative. Although the estimated elasticities are quite large in some cases, they are all well below unity.

71. For Japan, Dai-ichi Life (2004) also finds a low elasticity of consumer price inflation to import price inflation when relating consumer price inflation to the Japanese output gap, the money growth rate and a four-quarter lead of import price inflation, 
grouped coefficients become smaller, implying that the speed of adjustment towards the 'desired' price level has slowed. In effect, the model is moving closer to being a pure inflation equation, rather than one that ultimately determines the price level.

95. The findings regarding inflation persistence also differ across countries, as can be seen from the final three columns in Table A1.1. The figures reported in these columns are the sum of all the coefficients on the current and lagged inflation terms in the set of explanatory variables. For all countries this sum is found to be significantly different from unity. The majority of the countries appear to show a decline in the persistence of inflation over the past decade, although for a small number of countries (Finland, Greece, Ireland, and Italy) there is evidence of a sizable increase. ${ }^{72}$ These mixed results are consistent with previous research, demonstrating that inflation persistence has risen in some countries but declined in others (Melick and Gelati, 2006).

96. One interpretation of changes in the extent of inflation persistence is that the relationship between inflation and inflation expectations has changed over time. The model given in equations [A1.1], [A1.2] and [1] is observationally equivalent to one in which current inflation is related to past inflation and a fixed level of inflation expectations. ${ }^{73}$ Hence, the change in the sum on the dynamic terms can be interpreted to mean that the weight given to inflation expectations (as opposed to past inflation) has changed. For this reason it is not possible to conclude that there is a long-run relationship between inflation and the output gap just because the sum of coefficients on the lagged inflation terms is below unity. Account also needs to be taken of inflation expectations.

\section{A1.3.3 Additional hypothesis tests}

97. The restricted system with split-sample coefficients is used as a baseline specification to examine a number of other related channels through which aspects of globalisation may have affected inflation. As discussed previously, a number of recent studies have presented evidence that the counterpart to the decline in the sensitivity of domestic inflation rates to domestic demand conditions is a rise in the sensitivity to foreign demand conditions.

98. The estimated specification (equation [1]) automatically includes an indirect effect from foreign economic conditions mediated through import prices. As shown in Pain et al. (2005), import prices for each OECD economy are a weighted average of world export prices and prices in the importing economy. Export prices are in turn a function of competitors' prices in international markets and the price level in the exporting economy. So import prices will in part reflect capacity constraints and other cyclical conditions in the exporting economy. The extent to which they do so however, will differ across economies, depending on the extent of pricing to market by importers. In general, a higher level of pricing to market implies that import prices are more likely to reflect the business cycle in the importing rather than in the exporting economy or in world markets overall. ${ }^{74}$

72. For some countries the observed difference in persistence in the two parts of the sample period is not statistically significant.

73. This can be seen as follows by transforming a simplified version of equation [A1.1] as follows: $\Delta \ln P_{t}=\alpha+\beta \Delta \ln P_{t-1}=\beta \Delta \ln P_{t-1}+(1-\beta) \Delta \ln P^{e}+\xi$, where $\xi=\alpha-(1-\beta) \Delta \ln P^{e}$.

74. On average the weight of domestic prices in import prices is 0.64 for the United States compared to 0.49 for Japan and 0.35 for Germany, implying that pricing to market is more prevalent among US importers than among Japanese or German importers (see Pain et al., 2005, Table 10, Panel E). The differences are even more striking for export prices: the weight exporters attach to price developments in the exporting 
99. To test whether there are any additional effects from foreign output gaps over and above those reflected in import prices, equation [1] is augmented with an additional world output gap variable and separate tests are carried out for the joint significance of the world output gap term in all 21 equations in both sub-samples. ${ }^{75}$ The test results suggest that the world output gap does not have a significant influence on domestic inflation in either of the two sub-periods (see Table A1.5). Hence the indirect effect through import prices seems to be the only channel through which foreign economic conditions affect consumer price inflation. The coefficients on the domestic output gap are not affected by the inclusion of the foreign output gap; they remain significant with magnitudes that are close to the base specification. ${ }^{76}$

100. A second issue of interest is whether domestic consumer prices respond faster to changes in the prices of commodity imports as opposed to non-commodity imports. This issue is addressed by augmenting equation [1] with current and lagged changes of commodity import prices and then testing for the significance of those additional terms. As any differences in reaction of consumer prices to commodity and non-commodity import price changes are likely to be only temporary, the sum of the coefficients on the commodity import price changes is constrained to equal zero. ${ }^{77}$

101. On this basis, the analysis appears to suggest that the impact of commodity import prices indeed differs from the impact of non-commodity import prices (see Table A1.5). But this result is driven by a small number of countries -- Canada and Germany in the first half of the sample and Canada, France and Ireland in the second half. For the other countries in the sample, the speed of the response of domestic consumer prices to import price changes seems not to vary with the type of goods being imported (the corresponding $p$-values are 0.17 and 0.20 , respectively). ${ }^{78}$

102. Given the findings of these hypothesis tests, the restricted system of equations estimated for 1995-2005 is used for the scenario analyses described in detail in the main paper.

country is estimated to be 0.08 for the United States, 0.28 for Japan and 0.18 for Germany (see Pain et al., 2005, Table 10, Panel D).

75. The coefficient on the world output gap is allowed to differ across countries in both sub-periods.

76. This finding differs from Borio and Filardo (2006) who demonstrate that measures of global economic slack have a significant influence the inflation process even after controlling for any indirect impact via import prices. However, the results of the two studies are not directly comparable as Borio and Filardo (2006) use the gap between headline and core inflation as the dependent variable.

77. The conclusions are not sensitive to this restriction.

78. Carrying out the same test for specification [A1.1] yielded similar results. The joint hypothesis that the impact does not differ across all 21 OECD could not be rejected at conventional significance levels (the respective $p$-value was 0.381 ). 
Table A1.1. Summary of the main regression results

\begin{tabular}{|c|c|c|c|c|c|c|c|c|c|c|c|}
\hline \multicolumn{4}{|c|}{ Error correction parameter } & \multicolumn{4}{|c|}{ Long-run import price coefficient } & \multicolumn{4}{|c|}{ Inflation persistence } \\
\hline & $1980-2005$ & 1980-1994 & 1995-2005 & & $1980-2005$ & 1980-1994 & $1995-2005$ & & $1980-2005$ & 1980-1994 & $1995-2005$ \\
\hline CAN & -0.051 & -0.059 & -0.020 & AUS & 2.312 & 2.074 & 2.608 & GRC & 0.972 & 0.648 & 0.937 \\
\hline DNK & {$[0.000]$} & {$[0.000]$} & {$[0.000]$} & BEL & {$[0.000]$} & {$[0.000]$} & {$[0.000]$} & SWE & 0.801 & 0.737 & 0.717 \\
\hline FRA & & & & CAN & & & & AUT & 0.781 & 0.804 & 0.515 \\
\hline ITA & & & & $\mathrm{CHE}$ & & & & FRA & 0.746 & 0.746 & 0.579 \\
\hline NOR & & & & ESP & & & & GBR & 0.739 & 0.740 & 0.481 \\
\hline AUS & -0.036 & -0.047 & & FIN & & & & DNK & 0.727 & 0.774 & 0.471 \\
\hline FIN & & & & $\mathrm{IRL}$ & & & & PRT & 0.708 & 0.683 & 0.579 \\
\hline GRC & & & & ITA & & & & $\mathrm{CHE}$ & 0.708 & 0.745 & 0.578 \\
\hline KOR & & & & NOR & & & & NLD & 0.684 & 0.638 & 0.617 \\
\hline PRT & & & & PRT & & & & BEL & 0.668 & 0.690 & 0.416 \\
\hline AUT & -0.020 & -0.022 & & SWE & & & & DEU & 0.639 & 0.674 & 0.385 \\
\hline BEL & {$[0.000]$} & [0.000] & & USA & & & & ESP & 0.632 & 0.564 & 0.531 \\
\hline $\mathrm{CHE}$ & & & & AUT & 0.618 & 0.378 & & JPN & 0.613 & 0.556 & 0.556 \\
\hline IRL & & & & FRA & & & & CAN & 0.500 & 0.500 & 0.524 \\
\hline JPN & & & & GRC & & & & ITA & 0.497 & 0.480 & 0.731 \\
\hline NLD & & & & JPN & & & & KOR & 0.396 & 0.396 & 0.309 \\
\hline SWE & & & & KOR & & & & FIN & 0.324 & 0.266 & 0.482 \\
\hline USA & & & & NLD & & & & NOR & 0.212 & 0.058 & 0.228 \\
\hline
\end{tabular}

Notes: The columns labelled 1980-2005 refer to specification [A1.2]; the columns labelled 1980-1994 and 1995-2005 refer to specification [1]. The values in parentheses denote the $p$ values of $t$-tests that the coefficients equal zero. Inflation persistence is measured as the sum on all lagged inflation terms, i.e. as $\sum_{j=1}^{4} \beta_{j i}+\sum_{j=0}^{4} \delta_{j i}+\sum_{j=0}^{4} \gamma_{j i}$ for each country $i$. 
ECO/WKP(2006)52

\begin{tabular}{|c|c|c|c|c|c|c|c|c|c|c|c|c|c|c|c|c|c|c|}
\hline & $\alpha_{0}$ & $\alpha_{1}$ & $\alpha_{2}$ & $\beta_{1}$ & $\beta_{2}$ & $\beta_{3}$ & $\beta_{4}$ & $\gamma_{0}$ & $\gamma_{1}$ & $\gamma_{2}$ & $\gamma_{3}$ & $\gamma_{4}$ & $\delta_{0}$ & $\delta_{1}$ & $\delta_{2}$ & $\delta_{3}$ & $\delta_{4}$ & $\alpha_{3}$ \\
\hline AUS & $\begin{array}{l}-0.031 \\
{[0.216]}\end{array}$ & $\begin{array}{c}-0.047 \\
{[0.000]}\end{array}$ & $\begin{array}{c}2.074 \\
{[0.000]}\end{array}$ & & $\begin{array}{c}0.084 \\
{[0.000]}\end{array}$ & $\begin{array}{c}0.263 \\
{[0.000]}\end{array}$ & & $\begin{array}{c}0.061 \\
{[0.000]}\end{array}$ & $\begin{array}{c}0.012 \\
{[0.011]}\end{array}$ & $\begin{array}{l}-0.022 \\
{[0.009]}\end{array}$ & & & $\begin{array}{c}0.059 \\
{[0.000]}\end{array}$ & & $\begin{array}{c}0.033 \\
{[0.000]}\end{array}$ & & & $\begin{array}{c}0.00068 \\
{[0.000]}\end{array}$ \\
\hline AUT & $\begin{array}{c}0.016 \\
{[0.657]}\end{array}$ & $\begin{array}{l}-0.022 \\
{[0.000]}\end{array}$ & $\begin{array}{c}0.378 \\
{[0.007]}\end{array}$ & $\begin{array}{c}0.118 \\
{[0.000]}\end{array}$ & $\begin{array}{c}0.269 \\
{[0.000]}\end{array}$ & $\begin{array}{c}0.263 \\
{[0.000]}\end{array}$ & & $\begin{array}{c}0.020 \\
{[0.000]}\end{array}$ & $\begin{array}{c}0.116 \\
{[0.000]}\end{array}$ & & $\begin{array}{c}0.060 \\
{[0.000]}\end{array}$ & $\begin{array}{l}-0.105 \\
{[0.000]}\end{array}$ & $\begin{array}{c}0.016 \\
{[0.103]}\end{array}$ & $\begin{array}{c}0.027 \\
{[0.019]}\end{array}$ & & $\begin{array}{c}0.020 \\
{[0.043]}\end{array}$ & & $\begin{array}{l}0.00031 \\
{[0.001]}\end{array}$ \\
\hline BEL & $\begin{array}{c}0.091 \\
{[0.017]}\end{array}$ & $\begin{array}{c}-0.022 \\
{[0.000]}\end{array}$ & $\begin{array}{c}2.074 \\
{[0.000]}\end{array}$ & $\begin{array}{c}0.858 \\
{[0.000]}\end{array}$ & $\begin{array}{l}-0.426 \\
{[0.000]}\end{array}$ & $\begin{array}{c}0.099 \\
{[0.000]}\end{array}$ & & $\begin{array}{c}0.182 \\
{[0.000]}\end{array}$ & $\begin{array}{l}-0.141 \\
{[0.000]}\end{array}$ & $\begin{array}{c}0.060 \\
{[0.023]}\end{array}$ & $\begin{array}{c}-0.046 \\
{[0.012]}\end{array}$ & $\begin{array}{c}0.022 \\
{[0.000]}\end{array}$ & $\begin{array}{c}0.193 \\
{[0.000]}\end{array}$ & $\begin{array}{l}-0.130 \\
{[0.000]}\end{array}$ & & $\begin{array}{c}0.020 \\
{[0.043]}\end{array}$ & & $\begin{array}{c}0.00012 \\
{[0.000]}\end{array}$ \\
\hline CAN & $\begin{array}{c}0.039 \\
{[0.017]}\end{array}$ & $\begin{array}{l}-0.059 \\
{[0.000]}\end{array}$ & $\begin{array}{c}2.074 \\
{[0.000]}\end{array}$ & $\begin{array}{c}0.118 \\
{[0.000]}\end{array}$ & & & & $\begin{array}{c}0.020 \\
{[0.000]}\end{array}$ & $\begin{array}{c}0.039 \\
{[0.000]}\end{array}$ & & & & $\begin{array}{c}0.193 \\
{[0.000]}\end{array}$ & & $\begin{array}{c}0.077 \\
{[0.000]}\end{array}$ & $\begin{array}{c}0.020 \\
{[0.043]}\end{array}$ & $\begin{array}{c}0.032 \\
{[0.025]}\end{array}$ & $\begin{array}{l}0.00025 \\
{[0.000]}\end{array}$ \\
\hline DNK & $\begin{array}{c}0.029 \\
{[0.172]}\end{array}$ & $\begin{array}{l}-0.059 \\
{[0.000]}\end{array}$ & $\begin{array}{c}0.378 \\
{[0.007]}\end{array}$ & $\begin{array}{c}0.118 \\
{[0.000]}\end{array}$ & $\begin{array}{c}0.084 \\
{[0.000]}\end{array}$ & & $\begin{array}{c}0.303 \\
{[0.000]}\end{array}$ & $\begin{array}{c}0.182 \\
{[0.000]}\end{array}$ & & & & & $\begin{array}{c}0.016 \\
{[0.103]}\end{array}$ & $\begin{array}{c}0.072 \\
{[0.000]}\end{array}$ & & & & $\begin{array}{l}0.00025 \\
{[0.000]}\end{array}$ \\
\hline FIN & $\begin{array}{c}0.039 \\
{[0.176]}\end{array}$ & $\begin{array}{l}-0.047 \\
{[0.000]}\end{array}$ & $\begin{array}{c}2.074 \\
{[0.000]}\end{array}$ & $\begin{array}{l}-0.172 \\
{[0.000]}\end{array}$ & $\begin{array}{c}0.084 \\
{[0.000]}\end{array}$ & $\begin{array}{c}0.099 \\
{[0.000]}\end{array}$ & & $\begin{array}{c}0.020 \\
{[0.000]}\end{array}$ & $\begin{array}{c}0.039 \\
{[0.000]}\end{array}$ & & $\begin{array}{c}0.021 \\
{[0.016]}\end{array}$ & $\begin{array}{c}0.022 \\
{[0.000]}\end{array}$ & $\begin{array}{c}0.016 \\
{[0.103]}\end{array}$ & $\begin{array}{c}0.027 \\
{[0.019]}\end{array}$ & $\begin{array}{c}0.077 \\
{[0.000]}\end{array}$ & & $\begin{array}{c}0.032 \\
{[0.025]}\end{array}$ & $\begin{array}{l}0.00026 \\
{[0.000]}\end{array}$ \\
\hline FRA & $\begin{array}{l}0.025 \\
{[0.02]}\end{array}$ & $\begin{array}{l}-0.059 \\
{[0.000]}\end{array}$ & $\begin{array}{c}0.378 \\
{[0.007]}\end{array}$ & $\begin{array}{c}0.480 \\
{[0.000]}\end{array}$ & & $\begin{array}{c}0.099 \\
{[0.000]}\end{array}$ & & $\begin{array}{c}0.084 \\
{[0.000]}\end{array}$ & $\begin{array}{l}-0.033 \\
{[0.000]}\end{array}$ & $\begin{array}{c}0.028 \\
{[0.000]}\end{array}$ & & & $\begin{array}{c}0.016 \\
{[0.103]}\end{array}$ & $\begin{array}{c}0.072 \\
{[0.000]}\end{array}$ & & & & $\begin{array}{c}0.00025 \\
{[0.000]}\end{array}$ \\
\hline DEU & $\begin{array}{c}0.079 \\
{[0.052]}\end{array}$ & $\begin{array}{l}-0.022 \\
{[0.000]}\end{array}$ & $\begin{array}{c}0.378 \\
{[0.007]}\end{array}$ & $\begin{array}{c}0.118 \\
{[0.000]}\end{array}$ & $\begin{array}{c}0.269 \\
{[0.000]}\end{array}$ & & & $\begin{array}{c}0.104 \\
{[0.000]}\end{array}$ & $\begin{array}{c}-0.033 \\
{[0.000]}\end{array}$ & & $\begin{array}{c}0.060 \\
{[0.000]}\end{array}$ & & $\begin{array}{c}0.104 \\
{[0.000]}\end{array}$ & & $\begin{array}{c}0.033 \\
{[0.000]}\end{array}$ & $\begin{array}{c}0.020 \\
{[0.043]}\end{array}$ & & $\begin{array}{l}0.00012 \\
{[0.000]}\end{array}$ \\
\hline GRC & $\begin{array}{c}0.552 \\
{[0.000]}\end{array}$ & $\begin{array}{l}-0.047 \\
{[0.000]}\end{array}$ & $\begin{array}{c}0.378 \\
{[0.007]}\end{array}$ & & $\begin{array}{c}0.084 \\
{[0.000]}\end{array}$ & & $\begin{array}{c}0.408 \\
{[0.000]}\end{array}$ & $\begin{array}{c}0.020 \\
{[0.000]}\end{array}$ & & $\begin{array}{c}0.028 \\
{[0.000]}\end{array}$ & & $\begin{array}{c}0.022 \\
{[0.000]}\end{array}$ & & & $\begin{array}{c}0.033 \\
{[0.000]}\end{array}$ & $\begin{array}{c}0.020 \\
{[0.043]}\end{array}$ & $\begin{array}{c}0.032 \\
{[0.025]}\end{array}$ & $\begin{array}{l}0.00068 \\
{[0.000]}\end{array}$ \\
\hline IRL & $\begin{array}{l}-0.008 \\
{[0.871]}\end{array}$ & $\begin{array}{l}-0.022 \\
{[0.000]}\end{array}$ & $\begin{array}{c}2.074 \\
{[0.000]}\end{array}$ & $\begin{array}{c}0.118 \\
{[0.000]}\end{array}$ & $\begin{array}{c}0.084 \\
{[0.000]}\end{array}$ & & $\begin{array}{c}0.212 \\
{[0.000]}\end{array}$ & $\begin{array}{c}0.084 \\
{[0.000]}\end{array}$ & & $\begin{array}{c}0.060 \\
{[0.023]}\end{array}$ & $\begin{array}{l}-0.046 \\
{[0.012]}\end{array}$ & $\begin{array}{c}0.111 \\
{[0.000]}\end{array}$ & $\begin{array}{c}0.059 \\
{[0.000]}\end{array}$ & & $\begin{array}{c}0.033 \\
{[0.000]}\end{array}$ & & & $\begin{array}{l}0.00051 \\
{[0.000]}\end{array}$ \\
\hline ITA & $\begin{array}{c}0.047 \\
{[0.014]}\end{array}$ & $\begin{array}{c}-0.059 \\
{[0.000]}\end{array}$ & $\begin{array}{c}2.074 \\
{[0.000]}\end{array}$ & $\begin{array}{c}0.232 \\
{[0.000]}\end{array}$ & & $\begin{array}{c}0.099 \\
{[0.000]}\end{array}$ & & $\begin{array}{c}0.061 \\
{[0.000]}\end{array}$ & $\begin{array}{c}0.012 \\
{[0.011]}\end{array}$ & & & & $\begin{array}{c}0.016 \\
{[0.103]}\end{array}$ & $\begin{array}{c}0.027 \\
{[0.019]}\end{array}$ & $\begin{array}{c}0.033 \\
{[0.000]}\end{array}$ & & & $\begin{array}{c}0.00033 \\
{[0.001]}\end{array}$ \\
\hline JPN & $\begin{array}{c}0.049 \\
{[0.159]}\end{array}$ & $\begin{array}{l}-0.022 \\
{[0.000]}\end{array}$ & $\begin{array}{c}0.378 \\
{[0.007]}\end{array}$ & & $\begin{array}{c}0.084 \\
{[0.000]}\end{array}$ & $\begin{array}{c}0.099 \\
{[0.000]}\end{array}$ & $\begin{array}{c}0.212 \\
{[0.000]}\end{array}$ & $\begin{array}{c}0.020 \\
{[0.000]}\end{array}$ & $\begin{array}{c}0.012 \\
{[0.011]}\end{array}$ & & & & $\begin{array}{c}0.104 \\
{[0.000]}\end{array}$ & $\begin{array}{c}0.027 \\
{[0.019]}\end{array}$ & & & & $\begin{array}{c}0.00012 \\
{[0.001]}\end{array}$ \\
\hline KOR & $\begin{array}{c}0.038 \\
{[0.402]}\end{array}$ & $\begin{array}{l}-0.047 \\
{[0.000]}\end{array}$ & $\begin{array}{c}0.378 \\
{[0.007]}\end{array}$ & $\begin{array}{c}-0.172 \\
{[0.000]}\end{array}$ & & $\begin{array}{c}0.099 \\
{[0.000]}\end{array}$ & $\begin{array}{c}0.303 \\
{[0.000]}\end{array}$ & $\begin{array}{c}0.061 \\
{[0.000]}\end{array}$ & $\begin{array}{c}0.039 \\
{[0.000]}\end{array}$ & & & & & & $\begin{array}{c}0.033 \\
{[0.000]}\end{array}$ & & $\begin{array}{c}0.032 \\
{[0.025]}\end{array}$ & $\begin{array}{l}0.00026 \\
{[0.000]}\end{array}$ \\
\hline NLD & $\begin{array}{c}0.057 \\
{[0.362]}\end{array}$ & $\begin{array}{l}-0.022 \\
{[0.000]}\end{array}$ & $\begin{array}{c}0.378 \\
{[0.007]}\end{array}$ & $\begin{array}{l}-0.213 \\
{[0.000]}\end{array}$ & $\begin{array}{c}0.084 \\
{[0.000]}\end{array}$ & & $\begin{array}{c}0.212 \\
{[0.000]}\end{array}$ & $\begin{array}{c}0.084 \\
{[0.000]}\end{array}$ & $\begin{array}{c}0.037 \\
{[0.001]}\end{array}$ & $\begin{array}{c}0.028 \\
{[0.000]}\end{array}$ & $\begin{array}{c}0.021 \\
{[0.016]}\end{array}$ & $\begin{array}{c}0.022 \\
{[0.000]}\end{array}$ & $\begin{array}{c}0.193 \\
{[0.000]}\end{array}$ & $\begin{array}{c}0.072 \\
{[0.000]}\end{array}$ & $\begin{array}{c}0.077 \\
{[0.000]}\end{array}$ & $\begin{array}{c}0.020 \\
{[0.043]}\end{array}$ & & $\begin{array}{l}0.00031 \\
{[0.000]}\end{array}$ \\
\hline NOR & $\begin{array}{c}0.037 \\
{[0.356]}\end{array}$ & $\begin{array}{c}-0.059 \\
{[0.000]}\end{array}$ & $\begin{array}{c}2.074 \\
{[0.000]}\end{array}$ & & $\begin{array}{c}-0.426 \\
{[0.000]}\end{array}$ & $\begin{array}{c}0.099 \\
{[0.000]}\end{array}$ & & $\begin{array}{c}0.020 \\
{[0.000]}\end{array}$ & $\begin{array}{c}0.037 \\
{[0.001]}\end{array}$ & & & & $\begin{array}{c}0.016 \\
{[0.103]}\end{array}$ & & $\begin{array}{c}0.077 \\
{[0.000]}\end{array}$ & & $\begin{array}{c}0.235 \\
{[0.000]}\end{array}$ & $\begin{array}{c}0.00025 \\
{[0.000]}\end{array}$ \\
\hline PRT & $\begin{array}{c}0.081 \\
{[0.000]}\end{array}$ & $\begin{array}{l}-0.047 \\
{[0.000]}\end{array}$ & $\begin{array}{c}2.074 \\
{[0.000]}\end{array}$ & $\begin{array}{c}0.480 \\
{[0.000]}\end{array}$ & $\begin{array}{c}0.084 \\
{[0.000]}\end{array}$ & & & $\begin{array}{c}0.104 \\
{[0.000]}\end{array}$ & $\begin{array}{c}-0.033 \\
{[0.000]}\end{array}$ & & & $\begin{array}{c}0.022 \\
{[0.000]}\end{array}$ & $\begin{array}{c}0.104 \\
{[0.000]}\end{array}$ & $\begin{array}{l}-0.130 \\
{[0.000]}\end{array}$ & & $\begin{array}{c}0.020 \\
{[0.043]}\end{array}$ & $\begin{array}{c}0.032 \\
{[0.025]}\end{array}$ & $\begin{array}{l}0.00020 \\
{[0.000]}\end{array}$ \\
\hline ESP & $\begin{array}{c}0.103 \\
{[0.013]}\end{array}$ & $\begin{array}{l}-0.047 \\
{[0.000]}\end{array}$ & $\begin{array}{c}2.074 \\
{[0.000]}\end{array}$ & $\begin{array}{l}-0.172 \\
{[0.000]}\end{array}$ & $\begin{array}{c}0.269 \\
{[0.000]}\end{array}$ & $\begin{array}{c}0.099 \\
{[0.000]}\end{array}$ & & & $\begin{array}{c}0.037 \\
{[0.001]}\end{array}$ & $\begin{array}{c}0.028 \\
{[0.000]}\end{array}$ & $\begin{array}{c}0.021 \\
{[0.016]}\end{array}$ & & $\begin{array}{c}0.016 \\
{[0.103]}\end{array}$ & $\begin{array}{c}0.180 \\
{[0.001]}\end{array}$ & $\begin{array}{c}0.033 \\
{[0.000]}\end{array}$ & $\begin{array}{c}0.020 \\
{[0.043]}\end{array}$ & $\begin{array}{c}0.032 \\
{[0.025]}\end{array}$ & $\begin{array}{l}0.00020 \\
{[0.000]}\end{array}$ \\
\hline SWE & $\begin{array}{c}0.074 \\
{[0.331]}\end{array}$ & $\begin{array}{l}-0.022 \\
{[0.000]}\end{array}$ & $\begin{array}{c}2.074 \\
{[0.000]}\end{array}$ & $\begin{array}{c}0.118 \\
{[0.000]}\end{array}$ & & $\begin{array}{c}0.099 \\
{[0.000]}\end{array}$ & $\begin{array}{c}0.212 \\
{[0.000]}\end{array}$ & $\begin{array}{c}0.104 \\
{[0.000]}\end{array}$ & & & & $\begin{array}{c}0.022 \\
{[0.000]}\end{array}$ & $\begin{array}{c}0.059 \\
{[0.000]}\end{array}$ & $\begin{array}{c}0.072 \\
{[0.000]}\end{array}$ & $\begin{array}{c}0.033 \\
{[0.000]}\end{array}$ & $\begin{array}{c}0.020 \\
{[0.043]}\end{array}$ & & $\begin{array}{l}0.00009 \\
{[0.000]}\end{array}$ \\
\hline $\mathrm{CHE}$ & $\begin{array}{c}0.033 \\
{[0.315]}\end{array}$ & $\begin{array}{l}-0.022 \\
{[0.000]}\end{array}$ & $\begin{array}{c}2.074 \\
{[0.000]}\end{array}$ & $\begin{array}{c}0.480 \\
{[0.000]}\end{array}$ & $\begin{array}{c}0.084 \\
{[0.000]}\end{array}$ & & & $\begin{array}{c}0.061 \\
{[0.000]}\end{array}$ & & & & & $\begin{array}{c}0.059 \\
{[0.000]}\end{array}$ & $\begin{array}{c}0.027 \\
{[0.019]}\end{array}$ & $\begin{array}{c}0.033 \\
{[0.000]}\end{array}$ & & & $\begin{array}{c}0.00012 \\
{[0.001]}\end{array}$ \\
\hline GBR & $\begin{array}{c}0.013 \\
{[0.795]}\end{array}$ & $\begin{array}{l}-0.022 \\
{[0.000]}\end{array}$ & $\begin{array}{c}2.074 \\
{[0.000]}\end{array}$ & & & $\begin{array}{c}0.099 \\
{[0.000]}\end{array}$ & $\begin{array}{c}0.303 \\
{[0.000]}\end{array}$ & $\begin{array}{c}0.020 \\
{[0.000]}\end{array}$ & $\begin{array}{c}0.039 \\
{[0.000]}\end{array}$ & $\begin{array}{c}0.028 \\
{[0.000]}\end{array}$ & & $\begin{array}{c}0.022 \\
{[0.000]}\end{array}$ & $\begin{array}{c}0.193 \\
{[0.000]}\end{array}$ & $\begin{array}{c}0.072 \\
{[0.000]}\end{array}$ & $\begin{array}{c}0.077 \\
{[0.000]}\end{array}$ & $\begin{array}{l}-0.145 \\
{[0.000]}\end{array}$ & $\begin{array}{c}0.032 \\
{[0.025]}\end{array}$ & $\begin{array}{l}0.00009 \\
{[0.000]}\end{array}$ \\
\hline USA & $\begin{array}{c}0.095 \\
{[0.001]}\end{array}$ & $\begin{array}{l}-0.022 \\
{[0.000]}\end{array}$ & $\begin{array}{c}2.074 \\
{[0.000]}\end{array}$ & $\begin{array}{c}0.118 \\
{[0.000]}\end{array}$ & & $\begin{array}{c}0.099 \\
{[0.000]}\end{array}$ & $\begin{array}{c}0.212 \\
{[0.000]}\end{array}$ & $\begin{array}{c}0.104 \\
{[0.000]}\end{array}$ & & & & & $\begin{array}{c}0.016 \\
{[0.103]}\end{array}$ & & & $\begin{array}{c}0.020 \\
{[0.043]}\end{array}$ & & $\begin{array}{c}0.00012 \\
{[0.001]}\end{array}$ \\
\hline
\end{tabular}

Note: The numbers in parenthesis are the $p$-values of exclusion restrictions on the coefficients. 
$\mathrm{ECO} / \mathrm{WKP}(2006) 52$

Table A1.3. Regression results, 1995-2005

\begin{tabular}{|c|c|c|c|c|c|c|c|c|c|c|c|c|c|c|c|c|c|c|}
\hline & $\overline{\alpha_{0}}$ & $\alpha_{1}$ & $\overline{\alpha_{2}}$ & $\beta_{1}$ & $\beta_{2}$ & $\beta_{3}$ & $\beta_{4}$ & $\gamma_{0}$ & $\gamma_{1}$ & $\gamma_{2}$ & $\gamma_{3}$ & $\gamma_{4}$ & $\delta_{0}$ & $\overline{\delta_{1}}$ & $\delta_{2}$ & $\begin{array}{l}\delta_{3} \\
\end{array}$ & $\delta_{4}$ & $\alpha_{3}$ \\
\hline AUS & $\begin{array}{c}0.047 \\
{[0.381]}\end{array}$ & $\begin{array}{l}-0.020 \\
{[0.000]}\end{array}$ & $\begin{array}{c}2.608 \\
{[0.000]}\end{array}$ & & $\begin{array}{c}0.084 \\
{[0.000]}\end{array}$ & $\begin{array}{c}0.263 \\
{[0.000]}\end{array}$ & & $\begin{array}{c}0.061 \\
{[0.000]}\end{array}$ & $\begin{array}{c}0.012 \\
{[0.011]}\end{array}$ & $\begin{array}{l}-0.022 \\
{[0.009]}\end{array}$ & & & $\begin{array}{c}0.059 \\
{[0.000]}\end{array}$ & & $\begin{array}{c}0.033 \\
{[0.000]}\end{array}$ & & & $\begin{array}{c}0.00029 \\
{[0.000]}\end{array}$ \\
\hline AUT & $\begin{array}{c}0.096 \\
{[0.012]}\end{array}$ & $\begin{array}{l}-0.020 \\
{[0.000]}\end{array}$ & $\begin{array}{c}2.608 \\
{[0.000]}\end{array}$ & $\begin{array}{c}0.118 \\
{[0.000]}\end{array}$ & & $\begin{array}{c}0.263 \\
{[0.000]}\end{array}$ & & $\begin{array}{c}0.020 \\
{[0.000]}\end{array}$ & $\begin{array}{c}0.116 \\
{[0.000]}\end{array}$ & & $\begin{array}{c}0.060 \\
{[0.000]}\end{array}$ & $\begin{array}{c}-0.105 \\
{[0.000]}\end{array}$ & $\begin{array}{c}0.016 \\
{[0.103]}\end{array}$ & $\begin{array}{c}0.027 \\
{[0.019]}\end{array}$ & & & & $\begin{array}{c}0.00029 \\
{[0.000]}\end{array}$ \\
\hline BEL & $\begin{array}{c}0.029 \\
{[0.465]}\end{array}$ & $\begin{array}{c}-0.020 \\
{[0.000]}\end{array}$ & $\begin{array}{c}2.608 \\
{[0.000]}\end{array}$ & $\begin{array}{c}0.363 \\
{[0.000]}\end{array}$ & $\begin{array}{c}-0.257 \\
{[0.000]}\end{array}$ & $\begin{array}{c}0.099 \\
{[0.000]}\end{array}$ & & $\begin{array}{c}0.182 \\
{[0.000]}\end{array}$ & $\begin{array}{l}-0.141 \\
{[0.000]}\end{array}$ & $\begin{array}{c}0.131 \\
{[0.000]}\end{array}$ & $\begin{array}{c}-0.046 \\
{[0.012]}\end{array}$ & $\begin{array}{c}0.022 \\
{[0.000]}\end{array}$ & $\begin{array}{c}0.193 \\
{[0.000]}\end{array}$ & $\begin{array}{c}-0.130 \\
{[0.000]}\end{array}$ & & & & $\begin{array}{c}0.00011 \\
{[0.002]}\end{array}$ \\
\hline CAN & $\begin{array}{c}0.094 \\
{[0.060]}\end{array}$ & $\begin{array}{l}-0.020 \\
{[0.000]}\end{array}$ & $\begin{array}{c}2.608 \\
{[0.000]}\end{array}$ & $\begin{array}{c}0.118 \\
{[0.000]}\end{array}$ & & & & $\begin{array}{c}0.020 \\
{[0.000]}\end{array}$ & & & & & $\begin{array}{c}0.193 \\
{[0.000]}\end{array}$ & & $\begin{array}{c}0.077 \\
{[0.000]}\end{array}$ & & $\begin{array}{c}0.116 \\
{[0.000]}\end{array}$ & $\begin{array}{l}0.00008 \\
{[0.001]}\end{array}$ \\
\hline DNK & $\begin{array}{c}0.224 \\
{[0.002]}\end{array}$ & $\begin{array}{l}-0.020 \\
{[0.000]}\end{array}$ & $\begin{array}{l}2.608 \\
{[0.000}\end{array}$ & $\begin{array}{c}0.118 \\
{[0.000]}\end{array}$ & $\begin{array}{c}0.084 \\
{[0.000]}\end{array}$ & & & $\begin{array}{c}0.182 \\
{[0.000]}\end{array}$ & & & & & $\begin{array}{c}0.016 \\
{[0.103]}\end{array}$ & $\begin{array}{c}0.072 \\
{[0.000]}\end{array}$ & & & & $\begin{array}{l}0.00008 \\
{[0.001]}\end{array}$ \\
\hline FIN & $\begin{array}{c}0.069 \\
{[0.291]}\end{array}$ & $\begin{array}{l}-0.020 \\
{[0.000]}\end{array}$ & $\begin{array}{c}2.608 \\
{[0.000]}\end{array}$ & & $\begin{array}{c}0.084 \\
{[0.000]}\end{array}$ & $\begin{array}{c}0.099 \\
{[0.000]}\end{array}$ & & $\begin{array}{c}0.020 \\
{[0.000]}\end{array}$ & & & $\begin{array}{c}0.021 \\
{[0.016]}\end{array}$ & $\begin{array}{c}0.022 \\
{[0.000]}\end{array}$ & $\begin{array}{c}0.016 \\
{[0.103]}\end{array}$ & $\begin{array}{c}0.027 \\
{[0.019]}\end{array}$ & $\begin{array}{c}0.077 \\
{[0.000]}\end{array}$ & & $\begin{array}{c}0.116 \\
{[0.000]}\end{array}$ & $\begin{array}{l}0.00011 \\
{[0.002]}\end{array}$ \\
\hline FRA & $\begin{array}{c}0.062 \\
{[0.058]}\end{array}$ & $\begin{array}{c}-0.020 \\
{[0.000]}\end{array}$ & $\begin{array}{c}2.608 \\
{[0.000]}\end{array}$ & $\begin{array}{c}0.314 \\
{[0.000]}\end{array}$ & & $\begin{array}{c}0.099 \\
{[0.000]}\end{array}$ & & $\begin{array}{c}0.084 \\
{[0.000]}\end{array}$ & $\begin{array}{c}-0.033 \\
{[0.000]}\end{array}$ & $\begin{array}{c}0.028 \\
{[0.000]}\end{array}$ & & & $\begin{array}{c}0.016 \\
{[0.103]}\end{array}$ & $\begin{array}{c}0.072 \\
{[0.000]}\end{array}$ & & & & $\begin{array}{c}0.00008 \\
{[0.001]}\end{array}$ \\
\hline DEU & $\begin{array}{c}0.162 \\
{[0.001]}\end{array}$ & $\begin{array}{l}-0.020 \\
{[0.000]}\end{array}$ & $\begin{array}{c}2.608 \\
{[0.000]}\end{array}$ & $\begin{array}{c}0.118 \\
{[0.000]}\end{array}$ & & & & $\begin{array}{c}0.104 \\
{[0.000]}\end{array}$ & $\begin{array}{l}-0.033 \\
{[0.000]}\end{array}$ & & $\begin{array}{c}0.060 \\
{[0.000]}\end{array}$ & & $\begin{array}{c}0.104 \\
{[0.000]}\end{array}$ & & $\begin{array}{c}0.033 \\
{[0.000]}\end{array}$ & & & $\begin{array}{c}0.00011 \\
{[0.001]}\end{array}$ \\
\hline GRC & $\begin{array}{c}0.102 \\
{[0.267]}\end{array}$ & $\begin{array}{l}-0.020 \\
{[0.000]}\end{array}$ & $\begin{array}{c}2.608 \\
{[0.000]}\end{array}$ & & $\begin{array}{c}0.084 \\
{[0.000]}\end{array}$ & & $\begin{array}{c}0.635 \\
{[0.000]}\end{array}$ & $\begin{array}{c}0.020 \\
{[0.000]}\end{array}$ & & $\begin{array}{c}0.028 \\
{[0.000]}\end{array}$ & & $\begin{array}{c}0.022 \\
{[0.000]}\end{array}$ & & & $\begin{array}{c}0.033 \\
{[0.000]}\end{array}$ & & $\begin{array}{c}0.116 \\
{[0.000]}\end{array}$ & $\begin{array}{l}0.00029 \\
{[0.000]}\end{array}$ \\
\hline IRL & $\begin{array}{l}-0.079 \\
{[0.134]}\end{array}$ & $\begin{array}{l}-0.020 \\
{[0.000]}\end{array}$ & $\begin{array}{c}2.608 \\
{[0.000]}\end{array}$ & $\begin{array}{c}0.118 \\
{[0.000]}\end{array}$ & $\begin{array}{c}0.084 \\
{[0.000]}\end{array}$ & & $\begin{array}{c}0.212 \\
{[0.000]}\end{array}$ & $\begin{array}{c}0.084 \\
{[0.000]}\end{array}$ & & $\begin{array}{c}0.131 \\
{[0.000]}\end{array}$ & $\begin{array}{l}-0.046 \\
{[0.012]}\end{array}$ & $\begin{array}{c}0.111 \\
{[0.000]}\end{array}$ & $\begin{array}{c}0.059 \\
{[0.000]}\end{array}$ & & $\begin{array}{c}0.033 \\
{[0.000]}\end{array}$ & & & $\begin{array}{l}0.00048 \\
{[0.000]}\end{array}$ \\
\hline ITA & $\begin{array}{c}0.017 \\
{[0.742]}\end{array}$ & $\begin{array}{c}-0.020 \\
{[0.000]}\end{array}$ & $\begin{array}{c}2.608 \\
{[0.000]}\end{array}$ & $\begin{array}{c}0.483 \\
{[0.000]}\end{array}$ & & $\begin{array}{c}0.099 \\
{[0.000]}\end{array}$ & & $\begin{array}{c}0.061 \\
{[0.000]}\end{array}$ & $\begin{array}{c}0.012 \\
{[0.011]}\end{array}$ & & & & $\begin{array}{c}0.016 \\
{[0.103]}\end{array}$ & $\begin{array}{c}0.027 \\
{[0.019]}\end{array}$ & $\begin{array}{c}0.033 \\
{[0.000]}\end{array}$ & & & $\begin{array}{c}0.00011 \\
{[0.002]}\end{array}$ \\
\hline JPN & $\begin{array}{l}-0.064 \\
{[0.121]}\end{array}$ & $\begin{array}{l}-0.020 \\
{[0.000]}\end{array}$ & $\begin{array}{c}2.608 \\
{[0.000]}\end{array}$ & & $\begin{array}{c}0.084 \\
{[0.000]}\end{array}$ & $\begin{array}{c}0.099 \\
{[0.000]}\end{array}$ & $\begin{array}{c}0.212 \\
{[0.000]}\end{array}$ & $\begin{array}{c}0.020 \\
{[0.000]}\end{array}$ & $\begin{array}{c}0.012 \\
{[0.011]}\end{array}$ & & & & $\begin{array}{c}0.104 \\
{[0.000]}\end{array}$ & $\begin{array}{c}0.027 \\
{[0.019]}\end{array}$ & & & & $\begin{array}{l}0.00011 \\
{[0.002]}\end{array}$ \\
\hline KOR & $\begin{array}{c}0.437 \\
{[0.001]}\end{array}$ & $\begin{array}{l}-0.020 \\
{[0.000]}\end{array}$ & $\begin{array}{c}2.608 \\
{[0.000]}\end{array}$ & & & $\begin{array}{c}0.099 \\
{[0.000]}\end{array}$ & & $\begin{array}{c}0.061 \\
{[0.000]}\end{array}$ & & & & & & & $\begin{array}{c}0.033 \\
{[0.000]}\end{array}$ & & $\begin{array}{c}0.116 \\
{[0.000]}\end{array}$ & $\begin{array}{l}0.00011 \\
{[0.002]}\end{array}$ \\
\hline NLD & $\begin{array}{c}0.200 \\
{[0.012]}\end{array}$ & $\begin{array}{l}-0.020 \\
{[0.000]}\end{array}$ & $\begin{array}{c}2.608 \\
{[0.000]}\end{array}$ & $\begin{array}{l}-0.213 \\
{[0.000]}\end{array}$ & $\begin{array}{c}0.084 \\
{[0.000]}\end{array}$ & & $\begin{array}{c}0.212 \\
{[0.000]}\end{array}$ & $\begin{array}{c}0.084 \\
{[0.000]}\end{array}$ & $\begin{array}{c}0.037 \\
{[0.001]}\end{array}$ & $\begin{array}{c}0.028 \\
{[0.000]}\end{array}$ & $\begin{array}{c}0.021 \\
{[0.016]}\end{array}$ & $\begin{array}{c}0.022 \\
{[0.000]}\end{array}$ & $\begin{array}{c}0.193 \\
{[0.000]}\end{array}$ & $\begin{array}{c}0.072 \\
{[0.000]}\end{array}$ & $\begin{array}{c}0.077 \\
{[0.000]}\end{array}$ & & & $\begin{array}{l}0.00029 \\
{[0.000]}\end{array}$ \\
\hline NOR & $\begin{array}{c}0.075 \\
{[0.480]}\end{array}$ & $\begin{array}{l}-0.020 \\
{[0.000]}\end{array}$ & $\begin{array}{c}2.608 \\
{[0.000]}\end{array}$ & & $\begin{array}{c}-0.257 \\
{[0.000]}\end{array}$ & $\begin{array}{c}0.099 \\
{[0.000]}\end{array}$ & & $\begin{array}{c}0.020 \\
{[0.000]}\end{array}$ & $\begin{array}{c}0.037 \\
{[0.001]}\end{array}$ & & & & $\begin{array}{c}0.016 \\
{[0.103]}\end{array}$ & & $\begin{array}{c}0.077 \\
{[0.000]}\end{array}$ & & $\begin{array}{c}0.235 \\
{[0.000]}\end{array}$ & $\begin{array}{l}0.00008 \\
{[0.001]}\end{array}$ \\
\hline PRT & $\begin{array}{c}0.211 \\
{[0.001]}\end{array}$ & $\begin{array}{l}-0.020 \\
{[0.000]}\end{array}$ & $\begin{array}{c}2.608 \\
{[0.000]}\end{array}$ & $\begin{array}{c}0.314 \\
{[0.000]}\end{array}$ & $\begin{array}{c}0.084 \\
{[0.000]}\end{array}$ & & & $\begin{array}{c}0.104 \\
{[0.000]}\end{array}$ & $\begin{array}{l}-0.033 \\
{[0.000]}\end{array}$ & & & $\begin{array}{c}0.022 \\
{[0.000]}\end{array}$ & $\begin{array}{c}0.104 \\
{[0.000]}\end{array}$ & $\begin{array}{l}-0.130 \\
{[0.000]}\end{array}$ & & & $\begin{array}{c}0.116 \\
{[0.000]}\end{array}$ & $\begin{array}{l}0.00008 \\
{[0.001]}\end{array}$ \\
\hline ESP & $\begin{array}{c}0.191 \\
{[0.030]}\end{array}$ & $\begin{array}{l}-0.020 \\
{[0.000]}\end{array}$ & $\begin{array}{l}2.608 \\
{[0.000]}\end{array}$ & & & $\begin{array}{c}0.099 \\
{[0.000]}\end{array}$ & & & $\begin{array}{c}0.037 \\
{[0.001]}\end{array}$ & $\begin{array}{c}0.028 \\
{[0.000]}\end{array}$ & $\begin{array}{c}0.021 \\
{[0.016]}\end{array}$ & & $\begin{array}{c}0.016 \\
{[0.103]}\end{array}$ & $\begin{array}{c}0.180 \\
{[0.001]}\end{array}$ & $\begin{array}{c}0.033 \\
{[0.000]}\end{array}$ & & $\begin{array}{c}0.116 \\
{[0.000]}\end{array}$ & $\begin{array}{l}0.00008 \\
{[0.001]}\end{array}$ \\
\hline SWE & $\begin{array}{l}-0.055 \\
{[0.532]}\end{array}$ & $\begin{array}{l}-0.020 \\
{[0.000]}\end{array}$ & $\begin{array}{c}2.608 \\
{[0.000]}\end{array}$ & $\begin{array}{c}0.118 \\
{[0.000]}\end{array}$ & & $\begin{array}{c}0.099 \\
{[0.000]}\end{array}$ & $\begin{array}{c}0.212 \\
{[0.000]}\end{array}$ & $\begin{array}{c}0.104 \\
{[0.000]}\end{array}$ & & & & $\begin{array}{c}0.022 \\
{[0.000]}\end{array}$ & $\begin{array}{c}0.059 \\
{[0.000]}\end{array}$ & $\begin{array}{c}0.072 \\
{[0.000]}\end{array}$ & $\begin{array}{c}0.033 \\
{[0.000]}\end{array}$ & & & $\begin{array}{c}0.00008 \\
{[0.001]}\end{array}$ \\
\hline CHE & $\begin{array}{c}0.065 \\
{[0.082]}\end{array}$ & $\begin{array}{l}-0.020 \\
{[0.000]}\end{array}$ & $\begin{array}{c}2.608 \\
{[0.000]}\end{array}$ & $\begin{array}{c}0.314 \\
{[0.000]}\end{array}$ & $\begin{array}{c}0.084 \\
{[0.000]}\end{array}$ & & & $\begin{array}{c}0.061 \\
{[0.000]}\end{array}$ & & & & & $\begin{array}{c}0.059 \\
{[0.000]}\end{array}$ & $\begin{array}{c}0.027 \\
{[0.019]}\end{array}$ & $\begin{array}{c}0.033 \\
{[0.000]}\end{array}$ & & & $\begin{array}{c}0.00011 \\
{[0.002]}\end{array}$ \\
\hline GBR & $\begin{array}{c}0.072 \\
{[0.178]}\end{array}$ & $\begin{array}{l}-0.020 \\
{[0.000]}\end{array}$ & $\begin{array}{c}2.608 \\
{[0.000]}\end{array}$ & & & $\begin{array}{c}0.099 \\
{[0.000]}\end{array}$ & & $\begin{array}{c}0.020 \\
{[0.000]}\end{array}$ & & $\begin{array}{c}0.028 \\
{[0.000]}\end{array}$ & & $\begin{array}{c}0.022 \\
{[0.000]}\end{array}$ & $\begin{array}{c}0.193 \\
{[0.000]}\end{array}$ & $\begin{array}{c}0.072 \\
{[0.000]}\end{array}$ & $\begin{array}{c}0.077 \\
{[0.000]}\end{array}$ & $\begin{array}{l}-0.145 \\
{[0.000]}\end{array}$ & $\begin{array}{c}0.116 \\
{[0.000]}\end{array}$ & $\begin{array}{l}0.00008 \\
{[0.001]}\end{array}$ \\
\hline USA & $\begin{array}{c}0.147 \\
{[0.000]}\end{array}$ & $\begin{array}{l}-0.020 \\
{[0.000]}\end{array}$ & $\begin{array}{c}2.608 \\
{[0.000]}\end{array}$ & $\begin{array}{c}0.118 \\
{[0.000]}\end{array}$ & & $\begin{array}{c}0.099 \\
{[0.000]}\end{array}$ & $\begin{array}{c}0.212 \\
{[0.000]}\end{array}$ & $\begin{array}{c}0.104 \\
{[0.000]}\end{array}$ & & & & & $\begin{array}{c}0.016 \\
{[0.103]}\end{array}$ & & & & & $\begin{array}{l}0.00011 \\
{[0.002]}\end{array}$ \\
\hline
\end{tabular}

Note: The numbers in parenthesis are the $p$-values of exclusion restrictions on the coefficients 
ECO/WKP(2006)52

Table A1.4. Average elasticity of inflation with respect to import prices

\begin{tabular}{l|ccc}
\hline \hline & $1980-2005$ & $1980-1994$ & $1995-2005$ \\
\hline Norway & 0.63 & 0.59 & 0.66 \\
Belgium & 0.56 & 0.49 & 0.66 \\
Portugal & 0.53 & 0.47 & 0.62 \\
Ireland & 0.50 & 0.44 & 0.57 \\
Sweden & 0.46 & 0.39 & 0.55 \\
Finland & 0.40 & 0.36 & 0.47 \\
United Kingdom & 0.40 & 0.34 & 0.48 \\
Australia & 0.37 & 0.30 & 0.46 \\
Spain & 0.36 & 0.27 & 0.49 \\
Italy & 0.35 & 0.30 & 0.42 \\
Switzerland & 0.35 & 0.32 & 0.39 \\
Canada & 0.33 & 0.26 & 0.44 \\
United States & 0.24 & 0.19 & 0.31 \\
Netherlands & 0.17 & 0.10 & 0.76 \\
Korea & 0.15 & 0.09 & 0.65 \\
Denmark & 0.13 & 0.08 & 0.54 \\
Austria & 0.11 & 0.06 & 0.52 \\
Greece & 0.11 & 0.06 & 0.49 \\
France & 0.10 & 0.06 & 0.44 \\
Germany & 0.09 & 0.05 & 0.39 \\
Japan & 0.05 & 0.03 & 0.22 \\
\hline
\end{tabular}

Note: Average elasticities are calculated by multiplying the import content of consumption with the coefficient on the interaction term and then taking the arithmetic average over the respective period.

Table A1.5. Hypotheses tests

\begin{tabular}{l|c|c}
\hline \multicolumn{1}{c|}{ Hypothesis } & \multicolumn{2}{c}{$p$-value } \\
\cline { 2 - 3 } & $1980-1994$ & $1995-2005$ \\
\hline $\begin{array}{l}\text { The world output gap is jointly insignificant across all 21 } \\
\text { equations }\end{array}$ & 0.125 & 0.638 \\
\hline $\begin{array}{l}\text { Current and lagged changes of commodity prices are jointly } \\
\text { insignificant across all 21 equations }\end{array}$ & 0.016 & 0.000 \\
\hline \hline
\end{tabular}




\section{APPENDIX 2: GLOBALISATION AND COMMODITY PRICES}

\section{A2.1. Introduction}

103. This Appendix provides more details on the commodity price equations used in the scenario analyses in the main paper, giving a short summary of their main features and the associated tests undertaken. The approach used is relatively aggregative, with estimated equations for five broad commodity groups -- crude oil, metals and minerals, agricultural raw materials, food and tropical beverages. The oil price variable considered is that for Brent crude, while for the remaining commodity groupings the prices variables considered are the aggregate price indices compiled by the Hamburg Institute of World Economics (HWWA). ${ }^{79}$

104. The empirical approach adopted has been to estimate reduced form error-correction equations for the price of each commodity or commodity group in real terms. The variables used in this exercise are largely those suggested by earlier related studies, ${ }^{80}$ and include world GDP, the world output gap, separate output gaps for the OECD and non-OECD regions, the US short-term real interest and the US dollar effective exchange rate. ${ }^{81}$ All of these capture essentially demand-side influences on real prices. Time trends are also included, when significant, to capture longer-term factors and trends such as changes in the pattern of demand and technologies.

105. In addition, a number of additional variables are considered in order to capture the possible extent to which the growth of global commodity demand in recent years has been affected by rapid output and trade growth in the non-OECD economies (IMF, 2006b). In estimation, three particular alternative measures were considered -- the non-OECD share of world trade, the non-OECD share of world GDP and the (annualised) difference between GDP growth in the OECD and the non-OECD -- to reflect different aspects of regional usage intensities and technologies. Each of these measures has particular limitations, but nonetheless may help to capture some of the broad influences coming from the non-OECD on commodity demand and prices in recent years.

106. Tables A2.1 and A2.2 below report a selection of the final empirical results found for each particular commodity group. In most cases, the estimation sample runs from the second half of the 1970s through to 2005. The main exception is for oil, with the reported equations estimated on a sample period from the mid-1980s onwards, beginning at a point soon after the oil price had declined markedly in real terms. Attempts to estimate an equation using a sample starting in the mid-1970s resulted in the coefficients becoming insignificant. The following sections provide a summary of main considerations and features relevant to each individual commodity group in turn.

79. The weightings on individual commodities within these broad price indices will reflect global demand, rather than country-specific factors. In some cases important commodities for particular countries may not be included in the aggregate price measures at all.

80. See, for example, Holtham and Durand (1987), Adams and Ichino (1995), Hua (1998) and Rae and Turner (2001) and the related references and discussion given in section 4 of the main paper.

81. The output gap is measured as the ratio of actual GDP to potential GDP. 
ECO/WKP(2006)52

\section{A2.2. Oil prices}

107. For oil, the relevant estimation results suggest a choice of two equations, as shown in Table A2.1. In the first (equation [1]), the effects of strong growth in the non-OECD economies work through a levels term in world GDP and a dynamic term in the share of the non-OECD economies in total world trade. In the second (equation [2]), there is an additional variable - the differential in the GDP growth rates of the non-OECD and the OECD economies interacted with a dummy variable equal to unity from 2001 onwards. This provides a direct test of whether the growth rate differential has had a significant impact on oil prices. Both of these specifications may reflect sample specific effects, so they are not necessarily suitable for projecting future movements in prices.

108. In statistical terms, there is little difference between either of these specifications over the particular sample period employed. The coefficient on the dummied growth differential term is significant at the $10 \%$ level, and thus provides weak evidence that the comparatively stronger growth of the nonOECD economies over the past five years has helped to raise real oil prices. The effects of strong growth in the non-OECD will also be reflected in the world GDP variable and the growth of the share of total world trade accounted for by non-OECD economies.

109. In economic terms, the second specification appears more plausible as it has a markedly lower income elasticity than the other equation, although even in this equation the long-run income elasticity (at $0.75 \%$ ) is a little above the underlying income elasticity of demand for oil assumed by Brook et al. (2004) on the basis of selected estimates from other studies. Over time, energy demand growth may be expected to slow from the high rates seen over the past five years as non-OECD economies move towards less energyintensive forms of production.

110. Attempts were also made to follow Rae and Turner (2001), by separating the impact of positive values of the global output gap from negative ones as a test of possible asymmetries in demand effects. While the point estimates of coefficients obtained for positive change in gaps were larger than those on negative change terms, the differences were typically not found to be statistically significant.

111. A final feature of interest in the oil price equation is the significant negative coefficient on the change term in real short-term interest rates in the United States. (A similar term is also present in the final model for food prices.) This suggests that, in the short-term at least, there may some degree of substitution between the demand for commodities and that for particular types of financial asset (Frankel, 2006). But there was no significant evidence found for a negative longer-term relationship between commodity prices and the real interest rate.

\section{A2.3. Metals and minerals prices}

112. As shown in Figure 10, in real terms metals and minerals have been broadly constant over a relatively long period of time, but with periods of cyclical swings around that level. This is reflected in the estimation results in Table A2.2, with the level of world income or a time trend both being found to have an insignificant longer-term influence on the real price.

113. Over the final two years of the sample period, there have been substantial increases in real metals prices, which are not explained at all satisfactorily by the equation, even after allowing for short-term spillovers from changes in oil prices. Statistically, these increases appear to be directly associated with the strong growth of demand for metals in the non-OECD, reflected in the term in the differential between non-OECD output growth and OECD output growth which is found to be significant when added to the original specification. The inclusion of this variable enables satisfactory diagnostic tests to be obtained for the estimated equation. 


\section{A2.4. Agricultural raw materials prices}

114. The primary long-run influence on the price of agricultural raw materials is found to be a time trend, reflecting the extent to which the real price has fallen over time. There are also positive short-term effects from the growth of real oil prices and from the world output gap. The coefficient on the latter measure is not particularly robust and an alternative specification using the world GDP level rather than GDP relative to trend would fit the data equally well.

\section{A2.5. Food and tropical beverages prices}

115. Food and tropical beverages prices in real terms are also both found to follow a significant downward trend over time. In estimation, the cyclical effects from movements in the world output gap are found to be different from those for other commodity prices, with the impact of a rise in the output gap (the gap becomes more positive) being to generate a temporary increase in prices before a more marked decline after a few quarters. It is not clear what lies behind this finding, but it could reflect differences in the speed of responsiveness of supply in these markets.

\section{A2.6. The aggregate impact of changes in the output gap}

116. In addition to the scenarios discussed in section 4 of the main text, it is also of interest to explore the combined impact of changes in output gaps on commodity prices. To do this, two separate scenarios were examined using the set of estimated commodity price equations. In the first, output was reduced relative to trend by 1 percentage point for two years. In the second, output was reduced relative to trend by 2 percentage points for one year. Both of these "shocks" are large by historical standards. The resulting impact is shown in Figure A2.1, with the responses of the four non-oil prices also being weighted to give an aggregate response for all non-oil commodity prices. The simulations use the second oil price equation in Table A2.1. ${ }^{82}$

117. Overall, the results suggest that oil prices could rise markedly as a result of such changes, dropping up to $20 \%$ below their baseline level depending on the scenario considered. Thus cyclical effects in the world economy, as reflected in changing short-term output gaps, may therefore also have a marked effect on oil prices, at least for a while. The movements in non-oil prices are less prominent, declining initially by between 4 to $8 \%$, before moving above their baseline levels in the second or third year.

118. In contrast to non-oil commodity prices, the oil price just drifts gradually towards its baseline level following the temporary change in demand. This suggests there are differences in the extent and speed of the supply response between oil and non-oil commodities. For the non-oil commodities, the profile of prices appears to be consistent with what might be anticipated given a cobweb-type model for price adjustment, with the initial rise in demand generating an increase in supply in the following year(s), just as the increase in demand begins to wane. In the medium term, after four to five years, non-oil commodity prices are back at their baseline levels.

82. As the simulation is examining the effect of cyclical fluctuations, the level of world GDP is not changed in the oil price equation. 
Figure A2.1 Real commodity prices. Per cent effect of a temporary increase in output gaps

A. Real oil prices

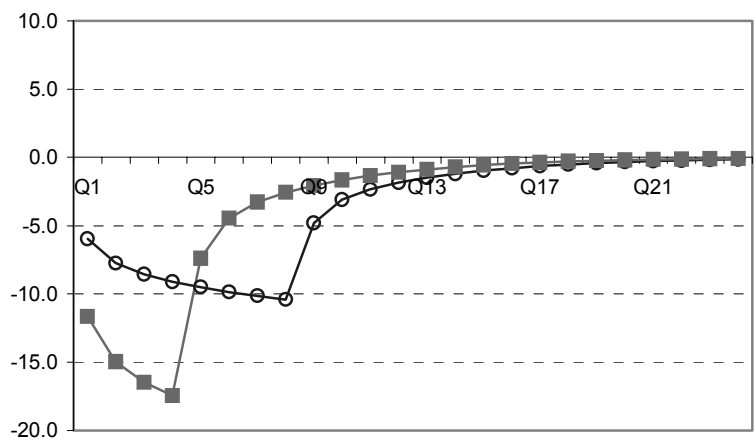

- oil a $1 \%$ decline in GDP relative to trend for 2 years

- oil a $2 \%$ decline in GDP relative to trend for 1 year

C. Real metals prices

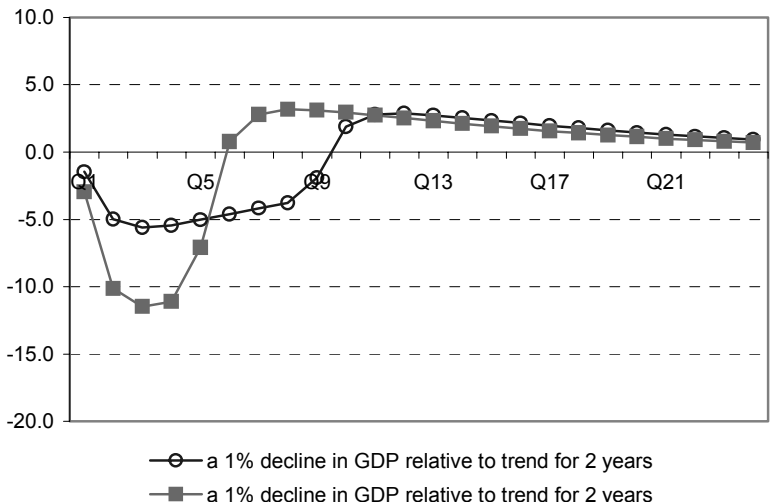

E. Real food prices

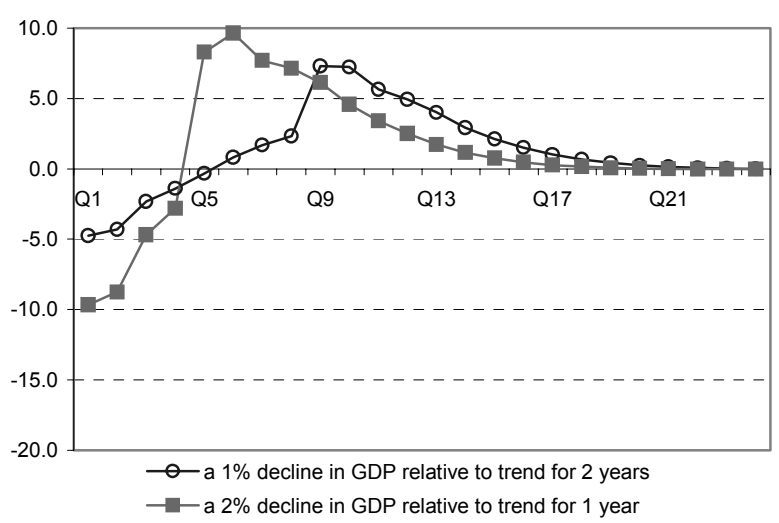

B. Real non-oil commodity prices

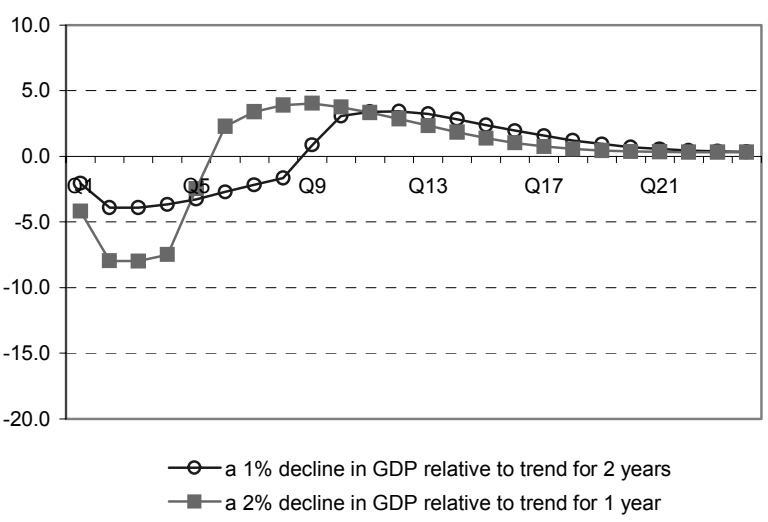

D. Real agricultural raw materials prices
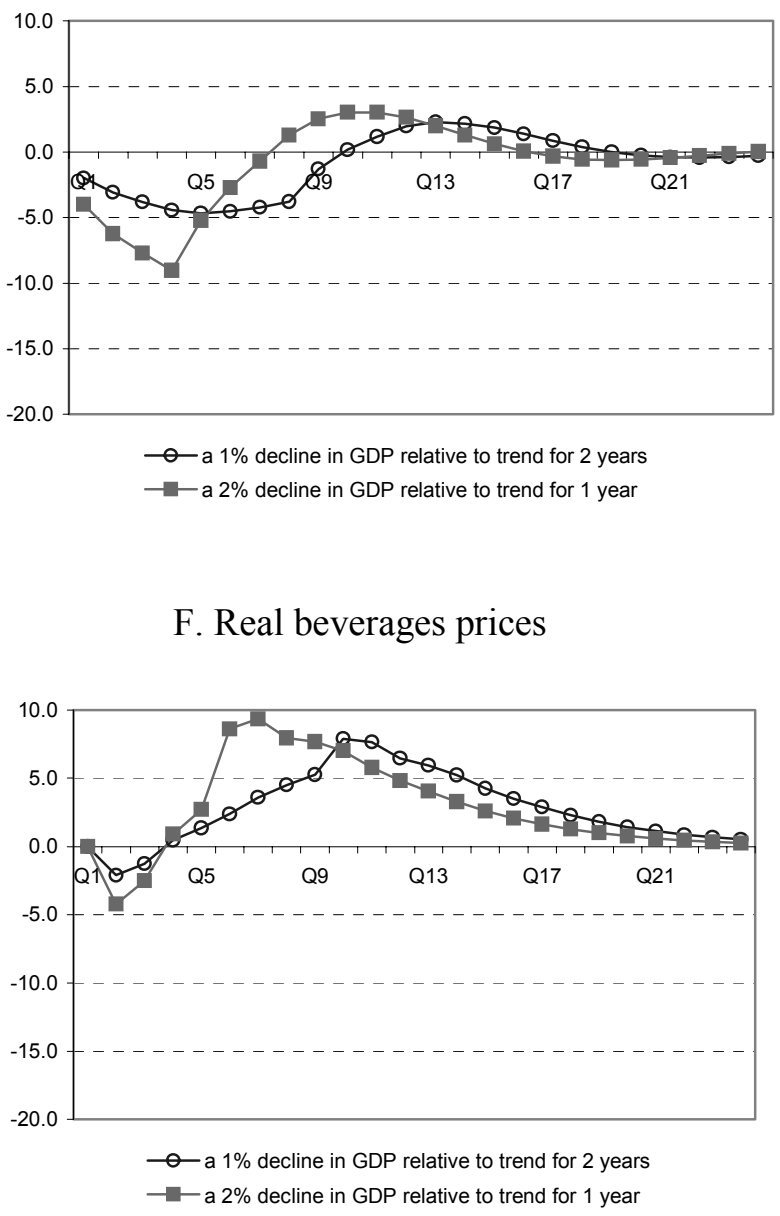
Table A2.1 Alternative oil price equations

\begin{tabular}{|c|c|c|c|c|}
\hline & \multicolumn{2}{|c|}{ [1] } & \multicolumn{2}{|c|}{ [2] } \\
\hline \multicolumn{5}{|l|}{ Long-run parameters } \\
\hline $\begin{array}{l}\text { In }(\text { world GDP })_{t-1} \\
\text { Dynamic parameters }\end{array}$ & 1.729 & 3.0 & 0.740 & 1.9 \\
\hline D2001-05*Non-OECD/OECD growth differential & & & 3.217 & 1.9 \\
\hline$\Delta$ (non-OECD output gap $)_{t}$ & 0.067 & 2.7 & 0.067 & 3.0 \\
\hline $\ln (\text { world output gap })_{\mathrm{t}-1}$ & 1.798 & 1.3 & 2.877 & 2.0 \\
\hline$\Delta \ln (\text { real oil price })_{t-1}$ & 0.172 & 2.1 & 0.248 & 2.6 \\
\hline$\Delta U S$ real interest rate $)_{t-1}$ & -0.023 & 2.3 & -0.021 & 2.1 \\
\hline Error correction mechanism $\mathrm{t}_{\mathrm{t}-1}$ & -0.152 & 3.1 & -0.257 & 3.5 \\
\hline Estimation period & \multicolumn{2}{|c|}{ 1986Q2-2005Q4 } & \multicolumn{2}{|c|}{ 1986Q2-2005Q4 } \\
\hline R2-adj. & \multicolumn{2}{|l|}{0.443} & \multicolumn{2}{|l|}{0.358} \\
\hline Standard error & \multicolumn{2}{|l|}{$9.95 \%$} & \multicolumn{2}{|l|}{$9.83 \%$} \\
\hline
\end{tabular}


Table A2.2 Estimation results for non-commodity prices

\begin{tabular}{|c|c|c|c|c|c|c|c|c|}
\hline & \multicolumn{2}{|c|}{ Metal prices } & \multicolumn{2}{|c|}{ Agricultural prices } & \multicolumn{2}{|c|}{ Food prices } & \multicolumn{2}{|c|}{$\begin{array}{c}\text { Tropical beverage } \\
\text { prices }\end{array}$} \\
\hline \multicolumn{9}{|l|}{ Long-run parameters } \\
\hline Trend & & & -0.002 & 5.9 & -0.005 & 5.7 & -0.009 & 5.0 \\
\hline \multicolumn{9}{|l|}{ Dynamic parameters } \\
\hline Non-OECD/OECD growth differentialt-2 & 0.628 & 2.2 & & & & & & \\
\hline$\Delta(\mathrm{OECD} \text { output gap })_{\mathrm{t}-1}$ & 0.033 & 3.2 & & & & & & \\
\hline$\Delta$ (non-OECD output gap $)_{t}$ & 0.015 & 1.9 & & & & & & \\
\hline$\Delta$ (world output gap)t & & & 0.020 & 2.5 & 0.046 & 3.3 & & \\
\hline$\Delta$ (world output gap) $)_{t-1}$ & & & & & & & 0.032 & 1.8 \\
\hline In(world output gap $)_{\mathrm{t}-1}$ & & & 0.579 & 2.0 & -0.696 & 1.7 & -1.075 & 2.1 \\
\hline$\Delta \ln (\text { real oil price })_{\mathrm{t}-2}$ & 0.082 & 2.4 & 0.053 & 2.1 & & & & \\
\hline$\Delta \mathrm{US}$ real interest rate $)_{\mathrm{t}-1}$ & & & & & -0.014 & 3.2 & & \\
\hline$\Delta \ln (\text { US real exchange rate })_{t-1}$ & & & & & 0.663 & 2.9 & & \\
\hline Error correction mechanism $\mathrm{t}_{\mathrm{t}-1}$ & -0.106 & 3.4 & -0.233 & 5.4 & -0.180 & 3.8 & -0.123 & 3.9 \\
\hline Estimation period & \multicolumn{2}{|c|}{ 1975Q4-2005Q4 } & \multicolumn{2}{|c|}{ 1976Q1-2005Q4 } & \multicolumn{2}{|c|}{ 1976Q1-2005Q4 } & \multicolumn{2}{|c|}{ 1979Q1-2005Q4 } \\
\hline Observations & \multicolumn{2}{|c|}{121} & \multicolumn{2}{|c|}{120} & \multicolumn{2}{|c|}{120} & \multicolumn{2}{|c|}{108} \\
\hline R2-adj. & \multicolumn{2}{|c|}{0.35} & \multicolumn{2}{|c|}{0.358} & \multicolumn{2}{|c|}{0.490} & \multicolumn{2}{|c|}{0.428} \\
\hline Standard error & \multicolumn{2}{|c|}{$4.70 \%$} & \multicolumn{2}{|c|}{$3.30 \%$} & \multicolumn{2}{|c|}{$5.80 \%$} & \multicolumn{2}{|c|}{$6.80 \%$} \\
\hline
\end{tabular}


$\mathrm{ECO} / \mathrm{WKP}(2006) 52$

\section{WORKING PAPERS}

The full series of Economics Department Working Papers can be consulted at www.oecd.org/eco/Working_Papers/

523. Identifying determinants of Germany's international price competitiveness - A structural VAR approach (November 2006) Martin Meurers

522. Short-term pain for long-term gain: the impact of structural reform on fiscal outcomes in EMU (November 2006) Paul van den Noord and Boris Cournède

521. Interactions between monetary and fiscal policy: How monetary conditions affect fiscal consolidation (November 2006) Rudiger Ahrend, Pietro Catte and Robert Price

520. Restoring fiscal sustainability in the Euro Area: raise taxes or curb spending? (October 2006) Boris Cournède and Frédéric Gonand

519. Should Measures of Fiscal Stance be Adjusted for Terms of Trade Effects (October 2006) David Turner

518. Monetary policy and inflation expectations in Latin America: Long-run effects and volatility spillovers (October 2006) Luiz de Mello and Diego Moccero

517. Social safety nets and structural adjustment (September 2006) Paul van den Noord, Nathalie Girouard and Christophe André

516. Adapting the Icelandic education system to a changing environment (September 2006) Hannes Suppanz

515. Forecasting monthly GDP for Canada (September 2006) Annabelle Mourougane

514. Finland's housing market: reducing risks and improving policies (September 2006) Laura Vartia

513. The Danish housing market: Less subsidy and more flexibility (September 2006) Espen Erlandsen, Jens Lundsgaard and Felix Huefner

512. Labour market reform in Germany: How to improve effectiveness (September 2006) Eckhard Wurzel

511. Removing obstacles to employment for women in Ireland (September 2006) Boris Cournède

510. Assessing Russia's non-fuel trade elasticities: Does the Russian economy react "normally" to exchange rate movements?

(September 2006) Christian Gianella and Corinne Chanteloup

509. Regulation, competition and productivity convergence (September 2006) Paul Conway, Donato De Rosa, Giuseppe Nicoletti and Faye Steiner

508. Improving education achievement and attainment in Luxembourg to compete in the labour market (September 2006) David Carey and Ekkehard Ernst

507. Raising economic performance by fostering product market competition in Germany (August 2006) Andrés Fuentes, Eckhard Wurzel and Andreas Reindl 
506. Regulation of financial systems and economic growth

(August 2006) Alain de Serres, Shuji Kobayakawa, Torsten Sløk and Laura Vartia

505. Enhancing Portugal's human capital

(August 2006) Bénédicte Larre and Stéphanie Guichard

504. Improving labour market performance in France

Améliorer la performance du marché du travail en France

(July 2006) Stéphanie Jamet

503. Wage setting in Finland: Increasing flexibility in centralised wage agreements (July 2006) Åsa Johansson

502. Taxation, business environment and FDI location in OECD countries (July 2006) Dana Hajkova, Giuseppe Nicoletti, Laura Vartia and Kwang-Yeol Yoo

501. The political economy of structural reform: Empirical evidence from OECD countries (July 2006) Jens Høj, Vincenzo Galasso, Giuseppe Nicoletti and Thai-Thanh Dang

500. Labour market performance, income inequality and poverty in OECD countries (July 2006) Jean-Marc Burniaux, Flavio Padrini and Nicola Brandt

499. Improving Public-Spending Efficiency in Czech Regions and Municipalities (July 2006) Philip Hemmings

498. Policies to Promote Innovation in the Czech Republic (July 2006) Alessandro Goglio

497. Getting Education Right for Long-Term Growth in the Czech Republic (July 2006) Alessandro Goglio

496. Assessing the 2005 Czech Proposals for Pension Reform (July 2006) Philip Hemmings and Edward Whitehouse

495. Poland's Education and Training: Boosting and Adapting Human Capital (July 2006) Paul O’Brien and Wojciech Paczynski

494. The Rates and Revenue of Bank Transaction Taxes (July 2006) Jorge Baca-Campodónico, Luiz de Mello and Andrei Kirilenko

493. Nothing Ventured, Nothing Gained: The Long-Run Fiscal Reward of Structural Reforms (July 2006) Peter Hoeller and Claude Giorno 